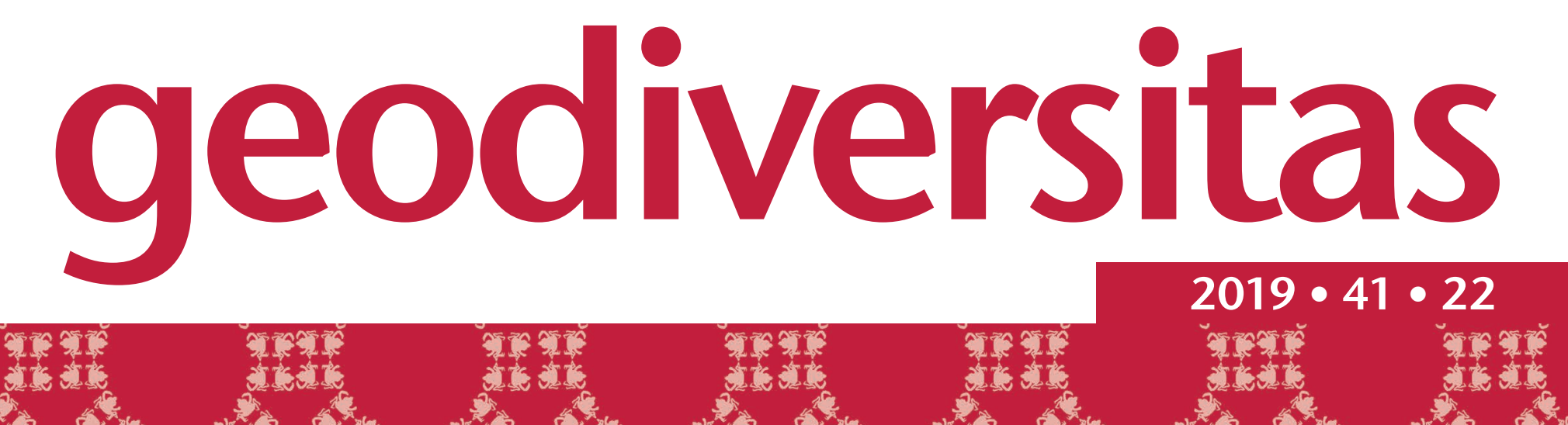
के का * New hypotheses concerning.

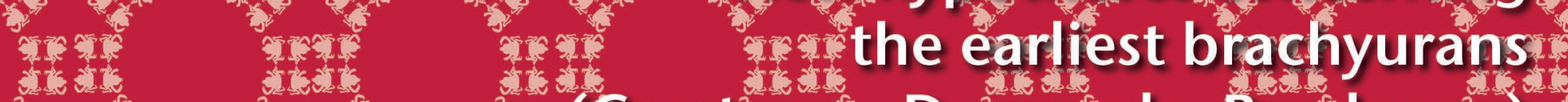
* (Crustacea, Decapoda Brachyura) (crustacea, Decapoda, Brachyura) and and $\sin 20$

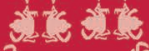

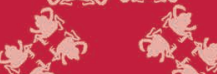

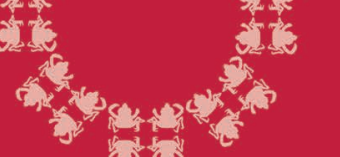

Danièle

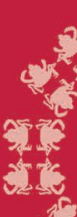

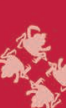
$x^{4}+40$ कास बरात

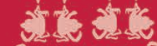
की

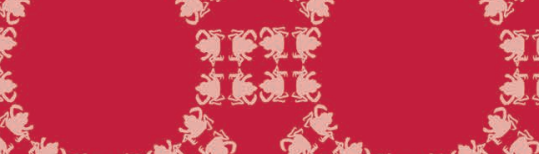


DiRECTEUR DE LA PUblication: Bruno David,

Président du Muséum national d'Histoire naturelle

RÉdACTEUR EN CHEF / EDITOR-IN-CHIEF: Didier Merle

ASSISTANTS DE RÉDACTION / ASSISTANT EDITORS: Emmanuel Côtez (geodiv@mnhn.fr)

Mise EN PAGE / PAGE LAYOUT: Emmanuel Côtez

COMITÉ SCIENTIFIQUE / SCIENTIFIC BOARD:

Christine Argot (MNHN, Paris)

Beatrix Azanza (Museo Nacional de Ciencias Naturales, Madrid)

Raymond L. Bernor (Howard University, Washington DC)

Alain Blieck (chercheur CNRS retraité, Haubourdin)

Henning Blom (Uppsala University)

Jean Broutin (UPMC, Paris)

Gaël Clément (MNHN, Paris)

Ted Daeschler (Academy of Natural Sciences, Philadelphie)

Bruno David (MNHN, Paris)

Gregory D. Edgecombe (The Natural History Museum, Londres)

Ursula Göhlich (Natural History Museum Vienna)

Jin Meng (American Museum of Natural History, New York)

Brigitte Meyer-Berthaud (CIRAD, Montpellier)

Zhu Min (Chinese Academy of Sciences, Pékin)

Isabelle Rouget (UPMC, Paris)

Sevket Sen (MNHN, Paris)

Stanislav Štamberg (Museum of Eastern Bohemia, Hradec Králové)

Paul Taylor (The Natural History Museum, Londres)

COUVERTURE / COVER:

Hyas coarctatus Leach, 1814, North Atlantic, West coast of Iceland, Expediton Pourquoi-Pas ?, 1912, Bouvier det., male $27 \times 20$ mm, extant (MNHN-IU-2014-23571).

Geodiversitas est indexé dans / Geodiversitas is indexed in:

- Science Citation Index Expanded (SciSearch $\left.{ }^{\circledR}\right)$

- ISI Alerting Services ${ }^{\circledR}$

- Current Contents ${ }^{\circledR} /$ Physical, Chemical, and Earth Sciences ${ }^{\circledR}$

- Scopus ${ }^{\circledR}$

Geodiversitas est distribué en version électronique par / Geodiversitas is distributed electronically by:

- BioOne ${ }^{\circledR}$ (http://www.bioone.org)

Les articles ainsi que les nouveautés nomenclaturales publiés dans Geodiversitas sont référencés par /

Articles and nomenclatural novelties published in Geodiversitas are referenced by:

- ZooBank ${ }^{\circledR}$ (http://zoobank.org)

Geodiversitas est une revue en flux continu publiée par les Publications scientifiques du Muséum, Paris Geodiversitas is a fast track journal published by the Museum Science Press, Paris

Les Publications scientifiques du Muséum publient aussi / The Museum Science Press also publish:

Adansonia, Zoosystema, Anthropozoologica, European Journal of Taxonomy, Naturae, Cryptogamie sous-sections Algologie, Bryologie, Mycologie.

Diffusion - Publications scientifiques Muséum national d'Histoire naturelle

CP $41-57$ rue Cuvier F-75231 Paris cedex 05 (France)

Tél. : 33 (0)1 40794805 / Fax: 33 (0)1 40793840

diff.pub@mnhn.fr / http://sciencepress.mnhn.fr

(C) Publications scientifiques du Muséum national d'Histoire naturelle, Paris, 2019

ISSN (imprimé / print): 1280-9659/ ISSN (électronique / electronic): 1638-9395 


\title{
New hypotheses concerning the earliest brachyurans (Crustacea, Decapoda, Brachyura)
}

\author{
Danièle GUINOT \\ ISYEB (CNRS, MNHN, EPHE, Sorbonne Université), \\ Institut Systématique Évolution Biodiversité, Muséum national d'Histoire naturelle, \\ case postale 53, 57 rue Cuvier, F-75231 Paris cedex 05 (France) \\ guinot@mnhn.fr
}

Submitted on 15 February 2019 | accepted on 21 May 2019 | published on 14 November 2019

"An epistemological obstacle will encrust any knowledge that is not questioned. Intellectual habits that were once useful and healthy can, in the long run, hamper research"

Gaston Bachelard, The Formation of the Scientific Mind

urn:Isid:zoobank.org:pub:37029578-A974-479C-A0D4-BA1F03BF4AE9

Guinot D. 2019. - New hypotheses concerning the earliest brachyurans (Crustacea, Decapoda, Brachyura). Geodiversitas 41 (22): 747-796. https://doi.org/10.5252/geodiversitas2019v41a22. http://geodiversitas.com/41/22

\section{ABSTRACT}

All Jurassic brachyuran taxa known to date are based solely upon dorsal carapaces, and only a limited number of Early and mid-Cretaceous crabs retain ventral parts. Therefore, all Jurassic taxa and many forms from the first half of the Cretaceous are carapace-based entities. All of them are considered to be "dromiaceans", podotremes to be precise. The recent discovery of an exceptionally well-preserved male crab from the Upper Cretaceous (lower Cenomanian) of Chiapas (Mexico), Archaeochiapasa mardoqueoi Guinot, Carbot-Chanona \& Vega, 2019, at first sight of a podotreme nature, has allowed a detailed description of its thoracic sternum and pleon, which revealed that it was actually a typical eubrachyuran, in need of a new family, Archaeochiapasidae Guinot, Carbot-Chanona \& Vega, 2019. This has brought back to life one of my earlier ideas about the possible non-podotreme nature of certain enigmatic Late Jurassic and Cretaceous Brachyura previously placed in various "dromiacean" (i.e., podotreme) families

KEY WORDS

Upper Jurassic, Cretaceous, Prosopidae,

Lecythocaridae,

Bucculentidae, Nodoprosopidae, Glaessneropsidae, Viaiidae,

Homolodromioidea, Homoloidea Glaessneropsoidea, Goniodromitinae, Sphaerodromiinae, Eubrachyura,

Callichimaeroida, podotreme,

new classification. and superfamilies. My investigations have led the me to formulate the present hypothesis that the extinct families Bucculentidae Schweitzer \& Feldmann, 2009 (currently assigned to the Homolodromioidea Alcock, 1900), Lecythocaridae Schweitzer \& Feldmann, 2009, Glaessneropsidae Schweitzer \& Feldmann, 2009, Nodoprosopidae Schweitzer \& Feldmann, 2009, and Viaiidae Artal, Van Bakel, Fraaije, Jagt \& Klompmaker, 2012 (all four in Glaessneropsoidea Schweitzer \& Feldmann, 2009) might, in fact (at least for some of them), be true eubrachyurans (Eubrachyura Saint Laurent, 1980). If correct, these assumptions would date the first "true crabs" as Jurassic, contrary to the currently held view that the earliest Eubrachyura (heterotremes) did not appear until the Cretaceous, and suggest that the evolutionary history of brachyurans started much earlier. This was unpredictable, at least for palaeontologists, but not so in view of a molecular estimate of decapod phylogeny that recovered the Majoidea Samouelle, 1819 as the oldest brachyuran lineage, with a divergence from other brachyurans from, at least, the Middle Triassic. The basal majoid family Oregoniidae Garth, 1958, which comprises only three extant genera, has several characters in common with Archaeochiapasidae; these leave little doubt about their close relationships. 
Proposals made here are inevitably based on provisional assumptions, until the characteristics of the ventral parts and pereiopods prove or refute them, either entirely or in part. Our science, which is based on the observation of specimens and then on descriptive, explanatory and, above all, predictive concepts, especially where incomplete fossil animals are concerned, should be conceived as a step forward, rather than an achievement, each of these steps being, sooner or later, replaced by a better one, or considered to be such. That is why all species and the composition of the Jurassic and Early Cretaceous genera and families will need to be checked in light of new perspectives. In contrast to the presumed eubrachyurans (see above), the Tanidromitidae Schweitzer \& Feldmann, 2008 and the apparently paraphyletic family Longodromitidae Schweitzer \& Feldmann, 2009 are podotremes, within the Dynomeniformia Guinot, Tavares \& Castro, 2013. The status and composition of the Goniodromitinae Beurlen, 1932 (in the Dromiidae De Haan, 1833), clearly paraphyletic, are briefly revised, while some genera, such as Distefania Checchia-Rispoli, 1917, are tentatively assigned to the Sphaerodromiinae Guinot \& Tavares, 2003. A table summarises the changes in classification implied by these new proposals and research directions. Some remarks on the new section Callichimaeroida Luque, Feldmann, Vernygora, Schweitzer, Cameron, Kerr, Vega, Duque, Strange, Palmer \& Jaramillo, 2019 are provided, as well as on the the putatively callichimaeroid-like family Retrorsichelidae Feldmann, Tshudy \& Thomson, 1993.

\section{RÉSUMÉ}

Nouvelles hypothèses sur les Brachyoures les plus anciens (Crustacea, Decapoda, Brachyura).

Tous les taxons brachyoures du Jurassique connus à ce jour sont basés sur la seule carapace dorsale, et seulement un nombre limité de crabes du Crétacé inférieur et moyen ont leurs régions ventrales préservées. En conséquence, tous les taxons jurassiques et de nombreux taxons de la première moitié du Crétacé sont des entités basées sur la carapace. Tous sont considérés comme étant des «dromiacés», c'est-à-dire des podotrèmes. La découverte récente d'un crabe mâle exceptionnellement préservé du Crétacé supérieur (Cénomanien inférieur) des Chiapas (Mexique), Archaeochiapasa mardoqueoi Guinot, Carbot-Chanona \& Vega, 2019, à première vue d'apparence podotrème, a permis une description basée sur le sternum thoracique et révélé qu'il s'agissait en fait d'un eubrachyoure typique, méritant une nouvelle famille, Archaeochiapasidae Guinot, Carbot-Chanona \& Vega, 2019. Cela a donné naissance à une idée, précédemment conçue, d'une éventuelle nature non podotrème de certains Brachyoures énigmatiques du Jurassique supérieur et du Crétacé auparavant placés dans diverses familles et superfamilles de dromiacés (i.e. podotrèmes). Mes investigations m'ont conduite à formuler l'hypothèse que les familles éteintes Bucculentidae Schweitzer \& Feldmann, 2009 (actuellement attribuée aux Homolodromioidea Alcock, 1900), Lecythocaridae Schweitzer \& Feldmann, 2009, Nodoprosopidae Schweitzer \& Feldmann, 2009, Glaessneropsidae Schweitzer \& Feldmann, 2009, et Viaiidae Artal, Van Bakel, Fraaije, Jagt \& Klompmaker, 2012 (toutes quatre dans les Glaessneropsoidea Schweitzer \& Feldmann, 2009) pourraient en fait, tout au moins pour une partie d'entre elles, être de vrais Eubrachyoures (Eubrachyura Saint Laurent, 1980). Si ces suppositions s'avèrent exactes, cela ferait remonter les "vrais crabes" au Jurassique, en contradiction avec l'opinion en cours actuellement selon laquelle les premiers Eubrachyura (hétérotrèmes) seraient apparus seulement au Crétacé, et suggère que l'histoire évolutive des brachyoures a commencé beaucoup plus tôt. C'était imprévisible, du moins pour les paléontologistes, mais pas selon une estimation moléculaire de la phylogénie des Décapodes, qui a identifié les Majoidea Samouelle, 1819 comme la lignée brachyourienne la plus ancienne, avec une divergence du reste des Brachyura au moins pendant le Trias moyen. La famille basale de Majoidea des Oregoniidae Garth, 1958, qui n'est représentée que par trois genres actuels, partage avec les Archaeochiapasidae plusieurs caractères qui laissent peu de doute sur leurs relations de parenté. Les propositions présentées ici reposent inévitablement sur des hypothèses provisoires, jusqu'à ce que les caractères des parties ventrales et des périopodes les prouvent ou les réfutent, pour tout ou en partie. Notre science, qui est fondée sur l'observation

MOTS CLÉS

Jurassique supérieur,

Prosopidae,

Lecythocaridae, Bucculentidae, Nodoprosopidae, Glaessneropsidae, Viaiidae,

Longodromitidae, Tanidromitidae, Homolodromioidea, Homoloidea

Glaessneropsoidea,

Goniodromitinae,

Sphaerodromiinae, Eubrachyura,

Callichimaeroida, podotrèmes, nouvelle classification. de spécimens puis sur des concepts descriptifs, explicatifs et surtout prédictifs, d'autant plus lorsqu'il s'agit d'animaux fossiles souvent incomplets, doit être conçue comme une étape dans l'avancement de nos connaissances et non comme un acquis, chacune de ces étapes étant, tôt ou tard, remplacée par une meilleure, ou considérée comme telle. C'est pourquoi toutes les espèces jurassiques et du début du Crétacé ainsi que la composition des genres et des familles nécessitent d'être vérifiées à la lumière de nouvelles perspectives. Contrairement aux eubrachyoures présumés (voir ci-dessus), les Tanidromitidae Schweitzer \& Feldmann, 2008, ainsi que la famille apparemment paraphylétique des Longodromitidae Schweitzer \& Feldmann, 2009, sont des podotrèmes, au sein des Dynomeniformia Guinot, Tavares \& Castro, 2013. Le statut et la composition des Goniodromitinae Beurlen, 1932 (dans les Dromiidae De Haan, 1833), clairement paraphylétique, sont brièvement révisés, tandis que certains genres, comme Distefania Checchia-Rispoli, 1917, sont provisoirement attribués aux Sphaerodromiinae Guinot \& Tavares, 2003. Un tableau récapitule les changements dans la classification qu'impliquent ces nouvelles propositions et directions de recherches. Quelques remarques sur la nouvelle section Callichimaeroida Luque, Feldmann, Vernygora, Schweitzer, Cameron, Kerr, Vega, Duque, Strange, Palmer \& Jaramillo, 2019 sont exposées, ainsi que sur la famille Retrorsichelidae Feldmann, Tshudy \& Thomson, 1993 supposée proche par ces auteurs. 


\section{INTRODUCTION}

Our knowledge and classification of the earliest brachyurans, with first-known occurrences in the Lower Jurassic, are based solely upon dorsal carapaces, and all (or nearly all) Jurassic taxa are carapace-based entities. In contrast, a limited number of Early and mid-Cretaceous taxa preserve ventral parts, such as the Albian Ariecornibus schweitzerae Franțescu, 2014 (Franțescu 2014: fig. 7), the thoracic sternum of which is typical of the Homoloidea H. Milne Edwards, 1837, doing away with any doubts over its identity. Such information is not currently available for the highly diverse and occasionally strange, primitive-looking forms from the Jurassic and Lower and/or mid-Cretaceous, so that their affiliation, in the absence of any similar or or comparable carapace shapes amongst Late Cretaceous and younger faunas, ranks amongst the most challenging issues.

In the past, virtually all Jurassic crabs and most allied crabs of Early Cretaceous age have been placed en bloc in the large family Prosopidae von Meyer, 1860, within the Dromiacea De Haan, 1833. Their great age, coupled with the nature and development of grooves on the dorsal surface and the occasional preservation of rostrum and orbits, seemed sufficient to provide evidence of their podotreme nature, at that time, "dromiacean". I do subscribe to the expert views of palaeontologists, but a "shape-based categorization process" guides us in our pre-existing representation of carapace shape (Reindl et al. 2015, 2018). For example, if the curious Early Eocene crab Mithracia oppionii Larghi, 2002 (Larghi 2002), known merely from a subcircular, grooved carapace and assigned to the Micromaiinae Beurlen, 1930 within the Majoidea, had been found in Upper Jurassic sedimentary rocks, it would certainly have been referred to prosopids or allied forms. Another example: if the warty carapaces of the two Middle Eocene species of Wilsonimaia Blow \& Manning, 1996 (Blow \& Manning 1996: figs 5, 6), referred to the Majidae Samouelle, 1819, had been recovered from the Jurassic or Lower Cretaceous, they might have been regarded as belonging to a glaessneropsoid genus, maybe a Verrucarcinus Schweitzer \& Feldmann, 2009. Note that this works both ways. On the basis of its wide carapace of xanthoid appearance, Glaessner $(1929,1969)$ was the first who rightly recognised the non-eubrachyuran nature of the Albian Etyus Leach in Mantell, 1822 and Xanthosia Bell, 1863, both previously referred to the Eubrachyura Saint Laurent, 1980 by most authors (e.g., Schweitzer Hopkins et al. 1999), until spermathecae and a narrow sterno-pleonal depression completely filled by the pleon were recorded: this is the typical disposition of basal podotreme crabs (Guinot \& Tavares 2001).

Major questions are rarely asked. The inclusion of Jurassic crabs in the Dromiacea De Haan, 1833 implies that the female oviducts perforate the $\mathrm{P} 3$ coxae (coxal gonopores), which is the generalised malacostracan condition. But what we know about the paired spermathecae in prosopids or other Jurassic crabs, and also in early Cretaceous forms without preserved vental parts? When the thoracic sternum and the pleon are present, as in Dromilites belli Van Bakel, Robin, Charbonnier \& Saward, 2017 from the Ypresian of London Clay, assigned to the Sphaerodromiinae (Van Bakel et al. 2017), minute spermathecal apertures are expected to be located far back on the thoracic sternum and near very short sutures $7 / 8$, as in extant species (Guinot \& Tavares 2003: figs 21C, 24C; Guinot \& Quenette 2005: 298). And, in fact, Dromilites bucklandii (H. Milne Edwards, 1837) exhibits such a condition, as clearly shown by Schweitzer \& Feldmann (2010d: fig. 5, as Dromilites simplex Quayle \& Collins, 1981). According to Karasawa et al. (2011: 539, fig. 4), based on Basinotopus lamarckii (Desmarest, 1822), the female spermathecae are situated posteriorly in Basinotopinae, as previously stated by Van Bakel et al. (2009: 49) in B. tricornis Collins \& Jakobsen, 2004. Karasawa et al. (2011:533, 553) erroneously considered that the spermathecae were not paired in some Gymnopleura, while in reality they are only joined medially. Van Bakel et al. (2012b: 156, figs 57A-D, 58A-D, 59A, B, 61A) were the pioneers in illustrating the spermathecae in the Palaeocorystoidea. While spermatheca are known in Dakoticancroidea (Guinot 1993a; Guinot \& Tavares 2001; Artal et al. 2008; Schweitzer et al. 2019), in Etyidae (Guinot \& Tavares 2001), and in Diaulacidae Wright \& Collins, 1972 (in Diaulax carteriana Bell, 1863 from the Coniacian-Campanian, see Karasawa et al. 2011: fig. 5A), we have no idea about the spermathecae in fossil Dynomenidae Ortmann, 1892 and Homolodromiidae, in Prosopidae, Tanidromitidae, and in Goniodromitinae, as well as in all families of Glaessneropsoidea Patrulius, 1959.

Is it true that "All Jurassic and almost all Cretaceous crabs belong to Dromiacea", as stated by Krobicki \& Zaton (2016: 695), in accordance with now widely accepted perceptions? What prevents us from considering some of these putative "dromiaceans", or podotremes, as potential eubrachyurans? Is it possible that during the Jurassic "the Brachyura did not rise above the organizational level of the Dromiacea" (see Glaessner 1969: R440)?

The recent discovery of a small male crab from the Upper Cretaceous (lower Cenomanian) Sierra Madre Formation at the El Chango Lagerstätte in Chiapas State (Mexico), Archaeochiapasa mardoqueoi, Guinot, Carbot-Chanona \& Vega, 2019, which exhibits an exceptional three-dimensional preservation, allowed its description to be based not only on the dorsal carapace, both chelipeds and pereiopods, but also on remarkably preserved ventral structures such as mxp3, the pleon and the thoracic sternum (Fig. 1A-D). As a first outcome, this crab (which, at first sight, looked like a podotreme) actually was a true eubrachyuran, in need of a new family, the Archaeochiapasidae Guinot, Carbot-Chanona \& Vega, 2019 (Guinot et al. 2019), with reduced P5 or perhaps with both P4 and P5 reduced. Secondly, a comparison with other "dromiacean" taxa has revealed striking similarities to the Late Jurassic Lecythocaridae Schweitzer \& Feldmann, 2009 (within the Glaessneropsoidea Patrulius, 1959; see Schweitzer \& Feldmann 2009a), known exclusively from dorsal carapaces (Fig. 10) and until now included in the Dromiacea, i.e., considered to be of a podotreme nature. Why could the Lecythocaridae not be a potential representative of eubrachyuran crabs? Being first and foremost a neontologist, this is only one hypothesis that I put forward for assessment by palaeontologists. 
The fossil record of the earliest brachyurans is poor and almost exclusively based on the more robust dorsal side (carapace); appendages and ventral parts are very rarely found attached to carapaces (for exceptions, see Förster 1985, 1986; Garassino et al. 2005). The carapace material, which has a proportionally large surface area, was easily transported by water, but eventually destroyed. Therefore, current knowledge of Jurassic and Early Cretaceous crabs is based on relatively few examples of low fossilisation potential (Schäfer 1951; Bishop 1986; Plotnick 1986; Plotnick et al. 1988; Müller et al. 2000; Klompmaker et al. 2013c) and exclusively on the dorsal carapace. For most prosopids sensu lato, isolated carapaces, frequently as internal moulds only, often with incomplete lateral margins and lacking orbits, are known to date. Eyes and cephalic appendages are unknown, but for a few exceptions (Vega et al. 2014).

The Middle Jurassic history of the Brachyura is represented mainly by single individuals of various species up to the Late Jurassic (Oxfordian) explosion in taxa and specimens. These primordial crabs lived on a silty sea floor (upper lower Pliensbachian) and their presumed ancestors were probably shallow-water organisms as well. Middle Jurassic crabs lived both in shallow, warm waters and on silty sea floors during the Bajocian/Bathonian, then were widely distributed across the Tethys Ocean in biohermal (Oxfordian) and reef facies (Kimmeridgian-Tithonian). The change from shallow, soft bottoms to an increased diversity of hard substrates with holes, crevices and other microhabitats as refuges during the Late Jurassic, coupled with the appearance of new communities, predators and food sources, has been a determining factor in brachyuran evolution (Fraaije 1996a, b; Hyžný et al. 2011). With both predator pressure and prey defence increasing over time, and predation being an important process in modern and past ecosystems (Glaessner 1969; Vermeij 2002; Klompmaker et al. 2013a, b, c), adaptations to particular habitats were enhanced by the availability of shelter. The small size of carapaces and the folded, reduced pleon early in the evolutionary history of brachyurans may have helped crabs to invade and radiate in Upper Jurassic reef environments, the reef increasing the number of places to hide from predators (Klompmaker et al. 2015; Fraaije et al. 2018). A narrow, elongated body and forward locomotion allowed primitive crabs to squeeze with ease into holes and crevices, whereas a wider body was more efficient in sideways locomotion to enter cavities or escape (Guinot et al. 2013). Carcinisation, externally exemplified by accomplishment of a wide body, made the acquisition of another type of habitat and behaviour possible.

Carrying behaviour with last pereiopod(s), a concealment strategy unique to Brachyura, is performed by practically all the basal extant families (Guinot \& Wicksten 2015: figs 71-11.2-4), except for extant Dynomenidae Ortmann, 1892, characterized by a vestigial P5. The fact that many earliest crabs from the Jurassic were certainly allied to extant homolodromiids (similar body and dorsal carapace shapes), and likely had equivalent specalisations of the last two pereiopods being able to be dorsally raised, would provide direct evidence of the early acquisition of a suite of behaviour-related adapta- tions. The discovery of comparably specialised last pereiopods (at the very least, as evidenced by the dorsal position of P4 and P5 coxae or corresponding arthrodial cavities) in early podotremes demonstrates carrying behaviour to be ancient, a relict type of behaviour and a survival technique in living crabs. It is reasonable to expect the earliest crabs to have had elongated and narrow bodies, with dorsal first pleonal somites and reduced last pereiopods (that are never preserved), similar to extant homolodromiids. The lateral views of carapaces of Pithonoton marginatum (von Meyer, 1842), P. aequilatum (von Meyer, 1857) and Eodromites grandis (von Meyer, 1857), as illustrated by Schweitzer \& Feldmann (2008a: pl. 1, figs B, C, D, respectively), show a posterior curvature of the body corresponding to a change in the alignment of the arthrodial cavities of P1-P5 that hint at dorsally located and carried last $\operatorname{pereiopod}(\mathrm{s})$.

Late Jurassic crabs were abundant, several thousands of specimens having been described so far (Wehner 1988; Müller et al. 2000; Schweitzer \& Feldmann 2008a, b, 2009a, b, c, d; 2010a, b, c; Crônier \& Boursicot 2009; Karasawa et al. 2011; Franțescu 2011, 2014; Schweigert \& Koppka 2011; Klompmaker et al. 2011a, 2013a; Starzyk 2013, 2015a, b, 2016; Starzyk et al. 2011, 2012; Fraaije et al. 2013; Robin et al. 2015; Schweigert \& Robins 2016; Van Bakel et al. 2012a, b; 2017; Jagt et al. 2015; Krobicki \& Zatoń 2008, 2016; Schweitzer et al. 2018a; Guinot et al. 2019; Schweigert 2019).

The grooves on the dorsal surface (Starzyk 2013, 2016), and, when preserved, the rostrum and orbits are the characters that are most often used. Even if the groove pattern turns out to be a reliable criterion, all of this naturally does not enable solid phylogenetic reconstitutions to be made and considerably limits our understanding of the early phases in the origin and evolutionary history of Brachyura. It is not possible to determine whether or not the classification of carapace-based podotreme taxa would be consistent with the ventral characters if such are eventually found, at least for some taxa, which comprise mainly: female gonopores on $\mathrm{P} 3$ coxae; paired and internalised spermatheca depending on phragma $7 / 8$; pleon filling entirely in width the space between the pereiopods (except for cyclodorippoids and dakoticancroids, see Artal et al. 2008) (Tavares \& Secretan 1993; Guinot \& Tavares 2001, 2003; Guinot \& Quenette 2005; Garassino 2009; Becker \& Scholtz 2017). A symplesiomorphic character of podotremes is the deeply concave posterior border of the carapace (generally described as "incised"; see Schweigert 2006) at the junction of the pleon with the carapace, probably to conform to its ventral folding; such a concave carapace border is a trait that is present only in basal brachyurans (podotremes and some basal eubrachyurans), both extinct and extant.

The possibly non-podotreme nature of the Late Jurassic Lecythocaridae would push back the first "true crabs" into the Jurassic, contrary to current opinions that the earliest eubrachyurans did not appear until the Cretaceous, with heterotremes (Schweitzer \& Feldmann 2005, 2015). This implies that the evolutionary history of Brachyura started much earlier (i.e., in pre-Jurassic times) than previously assumed. This finding now opens up new horizons. Could it be that some of the 


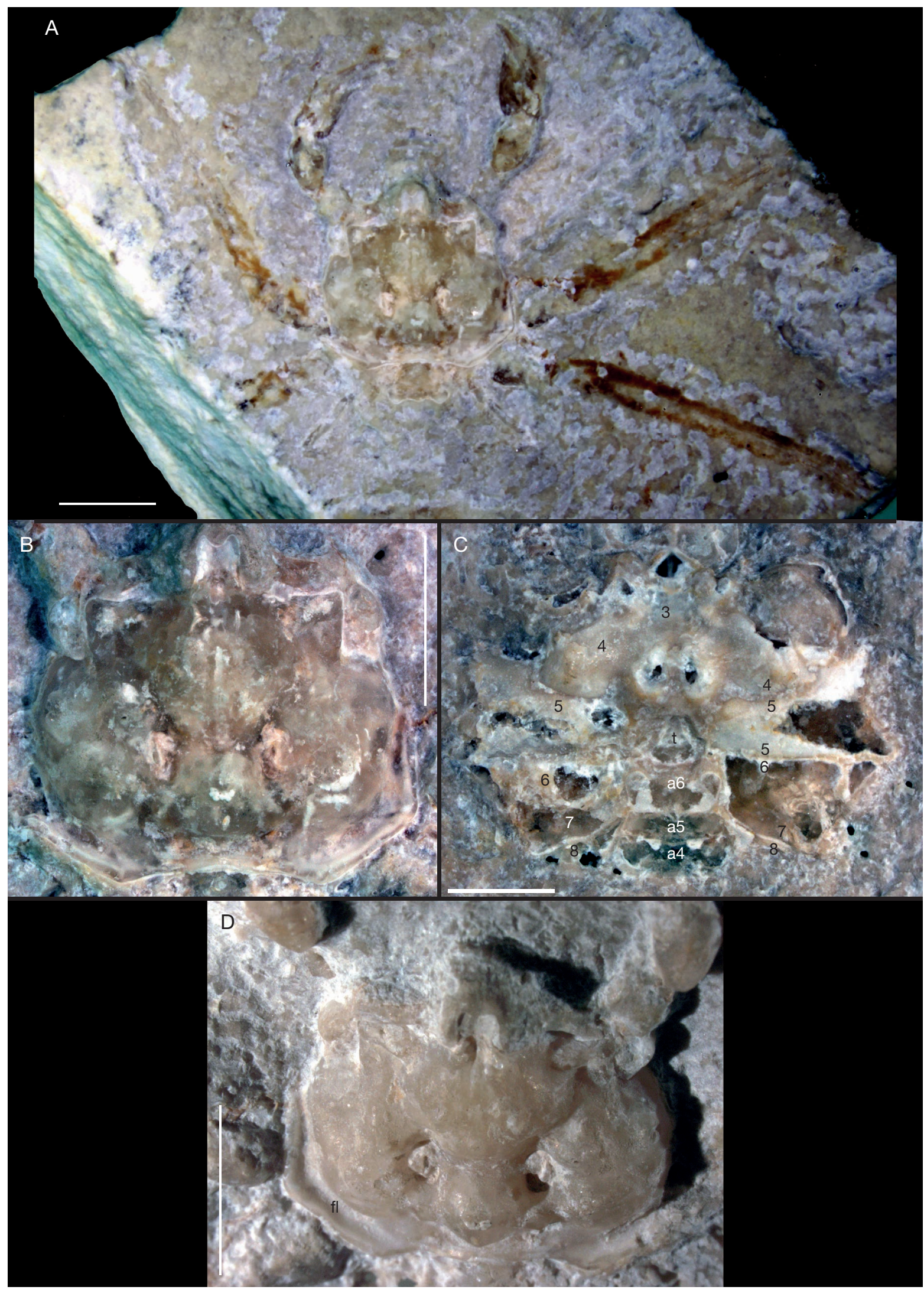

FIG. 1. - A-D, Archaeochiapasidae Guinot, Carbot-Chanona \& Vega, 2019. Archaeochiapasa mardoqueoi Guinot, Carbot-Chanona \& Vega, 2019, holotype, male, $10.3 \times 11.1 \mathrm{~mm}$ (IHNFG-5616), Mexico, Chiapas, El Chango Quarry, Sierra Madre Formation, lower Cenomanian, G. Carbot-Chanona coll. A, entire specimen in situ submerged in water; B, carapace; C, thoracic sternum and pleon; D, another view of carapace to show the flange. Abbreviations: a4-a6, pleonal somites 4-6; $\mathbf{f l}$, flange formed by thick rim and deep depression; $\mathbf{t}$, telson; $\mathbf{3}-\mathbf{8}$, sternites $3-8 ; \mathbf{4 / 5}, \mathbf{5 / 6 / , 7 / 8}$, sternal sutures 4/5, 5/6/, 7/8. Scale bars: A, B, D, 5 mm; C, 3 mm. 
"prosopids" sensu lato and species included in families currently assigned to the Dromiacea are, in fact, eubrachyurans, such as the Archaeochiapasidae, rather than podotremes? This was the starting point for a much-needed review of the taxonomy of some of the oldest known brachyuran genera. Contrary to my usual working method, my novel studies have been based solely upon overall carapace resemblances, on similarities or analogies, albeit with great care, as all palaeontologists who studied Jurassic and Cretaceous crabs have exercised before me. This is why only assumptions had to be developed.

A fragmentary carapace can be misleading and interpretation difficult. In this respect, the controversial case of Gastrodorus von Meyer, 1864 should be considered. Having initially been interpreted as a prosopid, then a primitive pagurid, a galatheoid or a homolid, it has turned out to be not a brachyuran crab. The genus has now been transferred to the Anomura, in its own family, the Gastrodoridae Van Bakel, Fraaije, Jagt \& Artal, 2008, and superfamily, the Gastrodoroidea Van Bakel, Fraaije, Jagt \& Artal, 2008 (Van Bakel et al. 2008; Klompmaker et al. 2011b), which is known exclusively from the Jurassic and upper Lower Cretaceous.

Crabs such as the Homolodromioidea, Dromioidea De Haan, 1833, Homoloidea, Etyoidea Guinot \& Tavares, 2003, Dakoticancroidea Rathbun, 1917, and Gymnopleura Bourne, 1922 (Bourne 1922) are all viewed as genuine podotremes on the basis of ventral characters. However, when only carapaces of podotreme and non-podotreme taxa are considered, the convergence of dorsal carapaces across brachyurans is misleading ("the carapace lies"), which has historically led taxonomists to group unrelated taxa. Conclusions based solely on the dorsal carapaces are speculative. But when, in a family, a Cretaceous specimen has fortunately been found with preserved ventral characters, it allows determining an associated carapace shape to the group, such as in the case of the Cenomanocarcinidae Guinot, Vega \& Van Bakel, 2008 from the Early Cretaceous (Guinot et al. 2008), which becomes a key to identifying allied taxa, differentiating between podotreme and non-podotreme (eubrachyuran) taxa and more accurately interpreting the correlated characters of the carapace.

\section{MATERIAL AND METHODS}

I will occasionally illustrate carapace reconstitutions, which, although in part subjective, have been carefully executed and can be taken to represent a rigorous interpretation of the groundplan.

The term "orbital area" (French: plage orbitaire) is here used to describe the special smooth structure associated with the orbit for the reception of the podophthalmite of the eyestalk (Guinot \& Richer de Forges 1995: 303), formerly referred to as "false orbit" (Wright \& Collins 1972) (see Davie et al. 2015a) and later renamed "augenrest" by Schweitzer \& Feldmann (2009a).

All measurements are in millimetres and recorded as maximum carapace length $(\mathrm{cl}) \times$ carapace width $(\mathrm{cw})$, respectively, inclusive of the rostrum. The following abbreviations are used in the text: G1, first male pleopod, or first gonopod; mxp3, third maxillipeds; P1-P5, first to fifth pereiopods (P1 as chelipeds; P2-P5 corresponding to ambulatory legs 2-5). Thoracic somites are numbered 1 to 8 . Pleonal somites are numbered 1 to 6 . Thoracic sternal sutures are referred to by the number of the two thoracic sternites that they involve, and thus are numbered $1 / 2$ to $7 / 8$.

\section{ABBREVIATIONS}

BSP Bayerische Staatsammlung für Paläontologie und historische Geologie, München (Munich);

IHNFG Secretaría de Medio Ambiente e Historia Natural, Tuxtla Gutiérrez, Chiapas;

MAB Oertijdmuseum, Boxtel;

MGSB Museo Geológico del Seminario de Barcelona;

MNHN Muséum national d'Histoire naturelle, Paris;

MPZ Musée des Sciences naturelles de l'Université de Saragosse, Zaragoza;

SMNS Staatliches Museum für Naturkunde, Stuttgart;

SYL collection privée (private collection) SYLLA, SauerlachArget;

USNM National Museum of Natural History, Smithsonian Institution, Washington D.C.

\section{SYSTEMATIC PALAEONTOLOGY}

As a result of finds of highly diverse Jurassic and Cretaceous crabs with a greater early disparity than previously assumed, major revisions in recent years have gradually and profoundly changed brachyuran taxonomy, so that the ancient prosopids now fall into several families. Prosopidae and closely related families were rarely referred to the Dromioidea, while a very large number have been referred to Homolodromioidea, all palaeontologists agreeing to recognise multiple affinities between Homolodromiidae and Prosopidae.

\section{Remarks on Homolodromioidea AlCOCK, 1900 AND HomolodromidDae Alcock, 1900}

Due to their location in the deep sea, their rarity and the fragility of the carapace, the representatives of Homolodromiidae are known in the Recent fauna only by an extremely limited material, with less than 25 species grouped into only two genera, Dicranodromia A. Milne Edwards, 1880 and Homolodromia A. Milne Edwards, 1880. When they were described, both were included in the Dromiacea, but Dicranodromia was assigned to the Dromiidae De Haan, 1833, while Homolodromia was assigned to the Homolidae H. Milne Edwards, 1837! According to Bouvier (1896: 50, 51), the prosopid Protocarcinus (synonym of Palaeinachus) longipes Woodward \& Salter, 1865 (now Homolus auduini (Eudes-Deslongchamps, 1835)) could be the Jurassic representative of these two living genera. In the same way, A. Milne-Edwards \& Bouvier (1902: 10), who placed both genera in the Dromiinae, wrote: "the extant Homolodromia are the barely modified representatives of the Jurassic Prosoponidae [sic]" ("les Homolodromia sont les représentants actuels, à peine modifiés, des Prosoponidae [sic] jurassiques”). Thereafter, the Homolodromiidae will be subordinated to the Dromiacea. 
Later, Guinot (1977, 1978, 1979, 1993a) raised the family to suprafamilial rank, Homolodromioidea, as the same rank as the Dromioidea. The familial level was however maintained by several neontologists (Abele \& Felgenhauer 1982; Bowman \& Abele 1982; Schram 1986; McLay 1993). Van Straelen (1925: 336-371) kept within Prosopidae the sole genus Prosopon Von Meyer, 1835 but included numerous Jurassic genera among the Recent Homolodromiidae. Wright \& Collins (1972: 18) wrote about the Homolodromiinae Alcock, 1900: "the Recent Homolodromiinae are like very early Prosopinae except for their bifurcate rostrum". Glaessner $(1933,1969)$ subordinated Homolodromia and Dicranodromia (as Homolodromiinae) to the Prosopidae within the Dromioidea, the Prosopinae being extinct at the end of the Mesozoic and considered the direct ancestors of the Homolodromiinae. Most authors used the suprafamilial rank, Homolodromioidea (e.g. Guinot 1977, 1978; Förster 1985, 1986; Förster et al. 1985; Feldmann \& Wilson 1988; Feldmann \& Tshudy 1989; Feldmann \& Keyes 1992; Feldmann et al. 1993, and subsequent authors). According to Wehner (1988), the family Prosopidae was divided into three subfamilies (Prosopinae von Meyer, 1860, Pithonotinae Glaessner, 1933, and Glaessneropsinae Patrulius, 1960).

Currently, there is a consensus to allocate to the Dromiacea sensu Schweitzer \& Feldmann (2009a), Karasawa et al. (2011) and in the new Treatise Online (Schweitzer et al. 2012a) three superfamilies: 1) Homolodromioidea Alcock, 1900; 2) Glaessneropsoidea Patrulius, 1959; and 3) Konidromitoidea Schweitzer \& Feldmann, 2010. However, I do not share identical views on all issues, so that is what I am attempting to do in this paper.

\section{Remarks on Homoloidea H. Milne Edwards, 1837} and Homolidae H. Milne EdWARds, 1837

While the majority of prosopids and closely related families have been referred the Dromiacea, reported cases of prosopids attributed to the Homoloidea are exceptional. Examples include Prosopon etheridgei Woodward, 1892 assigned to Lignihomola Collins, 1997 (Collins 1997: 63; Schweitzer et al. 2012b) and Prosopon longum Moericke, 1897 (Moericke 1897: 59, pl. 6, fig. 11) assigned to Tenuihomola Feldmann \& Schweitzer, 2009 (Feldmann \& Schweitzer 2009: fig. 5.1-5.3, as Tenuihomola longa) (Schweitzer et al. 2012b).

The first published family-series nomen based on the generic nomen Homola Leach, 1815 is the "tribe" Homoliens, French spelling (H. Milne Edwards 1837: 167, 180); then, "Homolidea", explicit Latinisation of Homoliens published by De Haan (1839: 102) who, however, did not recognise this taxon as valid. The nomen Homoliens $\mathrm{H}$. Milne Edwards, 1837 fulfils all the requirements making it nomenclaturally available. Given the general acceptance of the taxon Homoliens, the family, with its coordinated taxa, is to be attributed to the work and date of H. Milne Edwards (1837) (see Guinot et al. 2013: 301). In her proposal for a new classification of Brachyura, Guinot $(1977,1978)$ placed the Homoloidea apart from the "Dromiacea". Later, Guinot \& Tavares (2003: 45) and Guinot et al. (2008: 712) confirmed the existence of a definitely separate clade, supported by morphological, larval and spermatozoal studies, as basal as (perhaps more basal than) the Dromiacea, thus deserving a higher rank, similar to that of "Dromiacea". Several palaeontolongists (Schweitzer et al. 2004; Schweitzer \& Feldmann 2011) continued to consider Homoloidea only a dromiacean superfamily until Karasawa et al. (2011) and Schweitzer et al. (2012b) finally recognised a distinct section.

The superfamily Homoloidea contains three extant families (Guinot 1991; Guinot \& Richer de Forges 1995; Guinot et al. 2013): Homolidae, with a dorsal, paired linea homolica on the carapace dorsal surface; Latreilliidae Stimpson, 1858, with a lateral paired linea only at the level of the long, narrow 'neck'; Poupiniidae Guinot, 1991, without any lineae; and two extinct: Mithracitidae Števčić, 2005, without any lineae (Van Bakel et al. 2012c); Tithonohomolidae Feldmann \& Schweitzer, 2009, with only the interlineal portion of carapace, the extralineal regions of cephalothorax being not known (Schweitzer et al. 2012b: fig. 6).

When the carapace does not envelop the body and is a kind of cap (as in Poupiniidae) exuviation is facilitated and the external skeleton may be easily shed at ecdysis without the involvement of lineae. The carapace of Mithracites vectensis Gould, 1859 similarly seems to do not fold ventrally and not envelop the cephalothorax, at least backward (Guinot \& Tavares 2003: 535, fig. 19; Ossó et al. 2015: fig. 3).

The strength of the linea homolica, that is a weakly calcified area, varies considerably among the extant Homolidae. An intact linea homolica is well preserved in many homolid fossils (Glaessner 1969: fig. 221.4a-b). But, as the carapace can be broken at the level of the lineae during the taphonomic process, in some cases only the portion between the two lineae (interlineal portion) is preserved, whereas the rest (extralineal portion) is missing. An interesting case is that of Paromola vetula Crawford, 2008, in which only one of the extralineal flanks is preserved (Crawford 2008: figs 2, 3). A disarticulated corpse along the linea homolica or a specimen represented by an exuvia can be a homolid. Therefore, the recognition of preserved interlineal portions and lost extralineal portions of the carapace in fossil taxa is very important (Guinot et al. 2013). These fossil carapaces excluding extralineal flanks have misleading shapes (Schweitzer et al. 2004: figs 1-3) and can be easily confused with another family. The genus Navarrahomola Artal, Van Bakel, Fraaije, Jagt \& Klompmaker, 2012, with $N$. hispanica from the Lower Cretaceous (Albian)-Upper Cretaceous (Cenomanian) limestones at the Monte Orobe quarry, diagnosed by only an interlineal (or intralineal) carapace (Artal et al. 2012: fig. 3; see also Schweitzer et al. 2012b: fig. 2.3a, b), is exemplary in this respect.

Cases of early Homoloidea with preserved thoracic sterna that eliminates any doubt about their homoloid affiliation, such as the Albian Ariecornibus schweitzerae Franțescu, 2014 (Homolidae) and Belos trispinae Franțescu, 2014 (Latreilliidae) (Franțescu 2014: figs 7, 8, respectively), are rare. Whereas Homolidae with linea homolica are not problematic (Guinot \& Richer de Forges 1995; Collins 1997; Schweitzer et al. 2012b), how can we be sure of homolid identity when no lineae homolicae are present? 
REMARKS ON Dromioidea De HaAn, 1833

and Dromitdae De HaAn, 1833

The Dromiidae, a part of the major groups of basal crabs, includes two families: Dynomenidae (see McLay 1999) (with several subfamilies, see Guinot 2008); and Dromiidae (see McLay 1993, 2001) that comprises at least five subfamilies: Dromiinae De Haan, 1833, Hypoconchinae Guinot \& Tavares, 2003, Sphaerodromiinae Guinot \& Tavares, 2003, Basinotopinae Karasawa, Schweitzer \& Feldmann, 2011, and Goniodromitinae Beurlen, 1932 (the last two being extinct) (Guinot \& Tavares 2003).

\section{ClassifiCATION OF PODOTREME CRABS}

System of Karasawa et al. (2011) and Schweitzer et al. (2012a, $b ; 2017 a, b, c ; 2018 a, b)$

According to Karasawa et al. (2011:534) and in the new Treatise Online (Schweitzer et al. 2012a, b; 2017a, b, c; 2018a), the infraorder Brachyura comprises eight sections, the podotremes being assigned to seven sections, all at the same rank as the section Eubrachyura Saint Laurent, 1980, as follows:

- Section Dromiacea De Haan, 1833;

- Section Homoloida Karasawa, Schweitzer \& Feldmann, 2011;

- Section Torynommoida (Torynommoidea Glaessner, 1980);

- Section Etyoida (Etyoidea Guinot and Tavares, 2001);

- Section Raninoida Ahyong, Lai, Sharkey, Colgan \& Ng, 2007;

- Section Dakoticancroida (Dakoticancroidea Rathbun, 1917);

- Section Cyclodorippoida Ahyong, Lai, Sharkey, Colgan \& $\mathrm{Ng}, 2007$;

- Section Eubrachyura Saint Laurent, 1980.

Remark. This high-ranked taxonomy is not acceptable because it does not have a hierarchical structure. All these sections are not equivalent, and no consistency is respected. More inclusive groups cannot be ranked at higher category levels than less inclusive groups. Several properties (unicity, exhaustiveness, univocality, homogeneity, hierarchy, robustness) should be displayed by any taxonomic system to be theoretically satisfactory, acceptable by biologists worldwide, workable and efficient (Dubois 2005, 2007).

Composition of the section Dromiacea. In this system, the composition of this section is as follows:

- Superfamily Dromioidea De Haan, 1833:

- Family Basinotopidae Karasawa, Schweitzer \& Feldmann, 2011;

- Family Diaulacidae Wright \& Collins, 1972;

- Family Dromiidae De Haan, 1833;

- Family Dynomenidae Ortmann, 1892;

- Family Sphaerodromiidae Guinot \& Tavares, 2003;

- Family Xandarocarciidae Karasawa, Schweitzer, \& Feldmann, 2011.

- Superfamily Glaessneropsoidea Patrulius, 1959:

- Family Glaessneropsidae Patrulius, 1959;

- Family Lecythocaridae Schweitzer \& Feldmann, 2009;

- Family Longodromitidae Schweitzer \& Feldmann, 2009;

- Family Nodoprosopidae Schweitzer \& Feldmann, 2009;

- Family Viaiidae Artal, Van Bakel, Fraaije, Jagt \& Klompmaker, 2012.

- Superfamily Homolodromioidea Alcock, 1900:

- Family Bucculentidae Schweitzer \& Feldmann, 2009;
- Family Goniodromitidae Beurlen, 1932;

- Family Prosopidae von Meyer, 1860;

- Family Tanidromitidae Schweitzer \& Feldmann, 2009.

- Superfamily Konidromitoidea Schweitzer \& Feldmann, 2010:

- Family Konidromitidae Schweitzer \& Feldmann, 2010.

Composition of the section Homoloida De Haan, 1839.

It contains the families, as follows:

- Homolidae De Haan, 1839;

- Latreilliidae Stimpson, 1858;

- Poupiniidae Guinot, 1991;

- Mithracitidae Števčić, 2005;

- Tithonohomolidae Schweitzer \& Feldmann, 2009.

System of Guinot et al. (2013) (see Table 1)

Although the brachyuran section Podotremata Guinot, 1977, one of the most contentious issues in brachyuran phylogenetic research, is considered paraphyletic by geneticians (Ahyong et al. 2007; Tsang et al. 2014; Chu et al. 2015), it is however essential to differentiate between crabs with female coxal gonopores and spermathecae (i.e., podotremes), thus with external fertilisation, and those with vulvae (i.e., eubrachyurans), thus with internal fertilisation, the vulvae constituting the sole orifices for the intromission of gonopods, sperm storage, and the release of eggs (compare Guinot 1977; 1979; Ng et al. 2008; Van Bakel et al. 2012b; Guinot et al. 2013; Jagt et al. 2015; Becker \& Scholtz 2017). A paired spermatheca, as a secondary specialization of the phragma $7 / 8$, is an unambiguous synapomorphy of the Podotremata (Tavares \& Secretan 1993).

In order to put an end to the confusing taxonomy of the infraorder Brachyura, particularly in podotreme crabs, and to provide unambiguous nomina for higher-ranked podotreme taxa, Guinot et al. (2013: 17, 297, table 1) created a separate class-series nomenclature, relying on coherent rules (Dubois (2005, 2006a, b, 2007, 2010, 2012; Dubois \& Bour 2010). These new ranks should be used at higher levels for the allocation of the nomina of the robust podotreme fossil record. Notwithstanding the fact that Podotremata is monophyletic or paraphyletic, a strict account of the hierarchical relationships within the group is acceptable. Three high-ranked podotreme nomina, as subsections, were established, with the ending-iformia:

- Subsection Dynomeniformia Guinot, Tavares \& Castro, 2013;

- Subsection Homoliformia Karasawa, Schweitzer \& Feldmann, 2011;

- Subsection Cyclodorippiformia Guinot, Tavares \& Castro, 2013;

- Subsection Gymnopleura Bourne, 1922.

The nomen Gymnopleura was available, with its priority and original authorship, for the fourth section that includes raninoid and palaeocorystoid crabs. It should be noted that Homoliformia is recognised as a subsection separate from Dynomeniformia, both being considered basal podotremes.

According to Guinot \& Tavares (2003) and Guinot et al. (2013: tables 5, 6), the ancient section Podotremata sensu 
TABLE 1. - Proposed classification of podotreme crabs analysed in the present study.

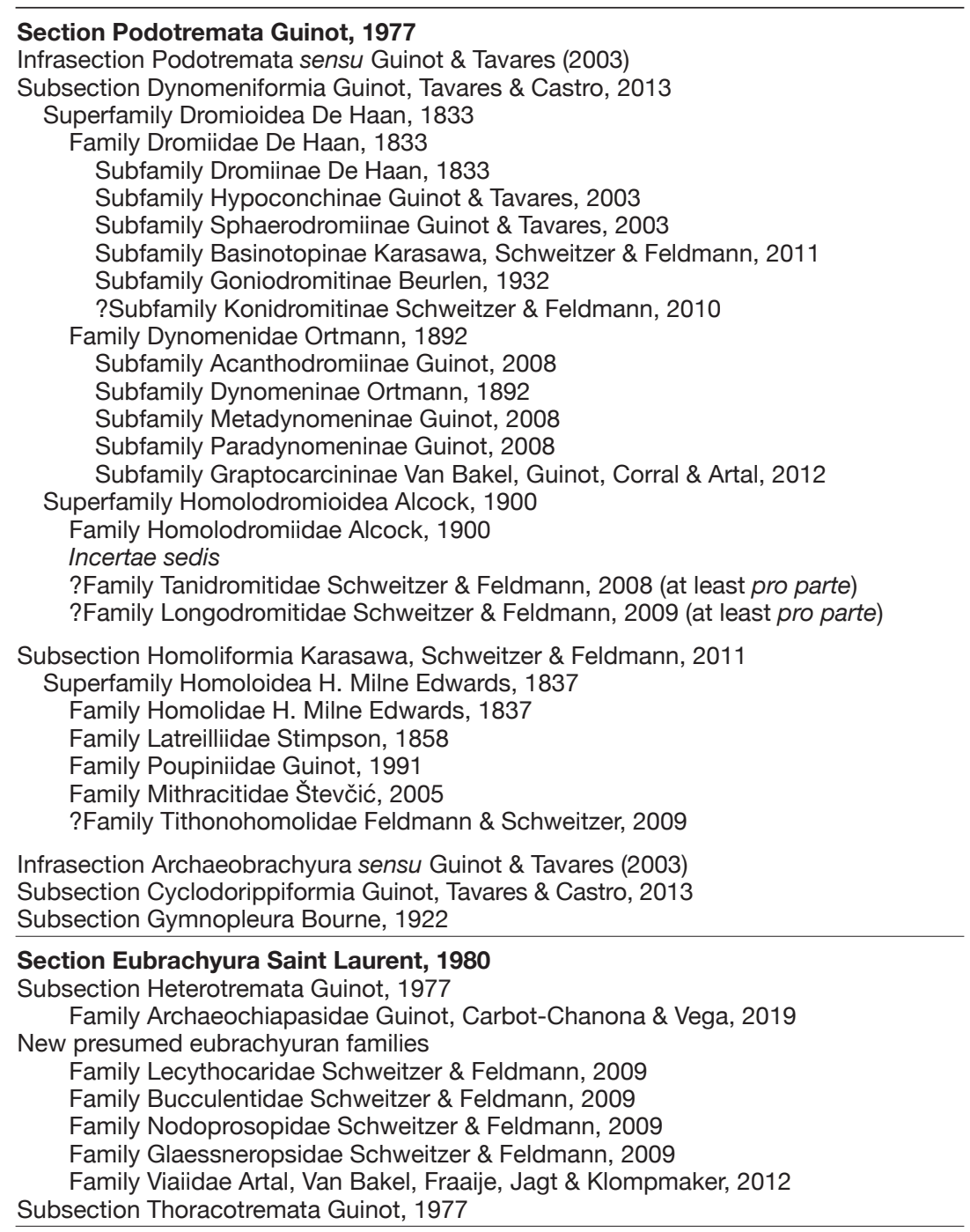

Guinot 1977) was divided into two "groups", these two additional subsidiary ranks being vaguely designated in the expectation of a future consensus. Preliminarily, we propose to name them "infrasection", as follows:

Infrasection Podotremata sensu Guinot \& Tavares (2003). Including the two basal lineages (see Table 1):

- subsection Dynomeniformia;

- subsection Homoliformia.

Infrasection Archaeobrachyura sensu Guinot \& Tavares (2003). Including two subsections (see Table 1):

- subsection Gymnopleura (with the superfamily Raninoidea

De Haan, 1839 and the extinct superfamily Palaeocorystoidea Lőrenthey in Lőrenthey \& Beurlen, 1929, see Van Bakel et al. 2012b);

- subsection Cyclodorippiformia Guinot, Tavares \& Castro, 2013 (with the superfamily Cyclodorippoidea Ortmann, 1892).
Finally, the Brachyura contains only two sections:

(1) Section Podotremata sensu Guinot (1977), often called "podotreme crabs", with two infrasections (Podotremata sensu Guinot \& Tavares [2003]; and Archaeobrachyura sensu Guinot \& Tavares [2003]);

(2) Section Eubrachyura Saint Laurent, 1980.

Several extinct podotreme lineages were left incertae sedis: Diaulacidae (or Diaulacinae) Wright \& Collins, 1972; Etyoidea Guinot \& Tavares, 2001 (Family Etyidae Guinot \& Tavares, 2001); Dakoticancroidea Rathbun, 1917 (Families Dakoticancridae Rathbun, 1917, and Ibericancridae Artal, Guinot, Van Bakel \& Castillo, 2008); Konidromitidae Schweitzer \& Feldmann, 2010; Torynommatidae Glaessner, 1980; Xandarocarcinidae Karasawa, Schweitzer \& Feldmann, 2011.

Based on Schweitzer \& Feldmann (2009a), on Karasawa et al. (2011) and Schweitzer et al. (2012a), at that time the classification of Guinot et al. (2013) had not challenged the Glaessneropsoidea Patrulius, 1959 (with all its components) as podotreme. 
System of Jagt et al. (2015)

The classification proposed by Jagt et al. (2015: table 1) broadly conforms to that of Guinot et al. (2013), similarly with Dakoticancroidea, Etyoidea, Torynommatoidea and Xandarocarcinidae as incertae sedis within the Podotremata.

System of Luque et al. (2019: table S2)

The classification proposed by Luque et al. (2019: table S2) is similar to that of Karasawa et al. (2011) and Schweitzer et al. (2012a, b; 2017a, b, c; 2018a), but with a notable addition: the introduction of a new section, Callichimaeroida Luque, Feldmann, Vernygora, Schweitzer, Cameron, Kerr, Vega, Duque, Strange, Palmer \& Jaramillo, 2019 (Luque et al. 2019), bringing the number of brachyuran sections to nine, all at the same rank and level (see also Luque et al. 2012). Interestingly, "Podotremata" is replaced by "podotreme grade"; and, within the Eubrachyura, Heterotremata is replaced by "heterotreme grade", and Thoracotremata by "thoracotreme grade".

The new section Callichimaeroida was designed to contain the superfamily Callichimaeroidea Luque, Feldmann, Vernygora, Schweitzer Cameron, Kerr, Vega, Duque, Strange, Palmer \& Jaramillo, 2019, which includes the lower Upper Cretaceous family Callichimaeridae Luque, Feldmann, Vernygora, Schweitzer, Cameron, Kerr, Vega, Duque, Strange, Palmer \& Jaramillo, 2019, and, tentatively, another one, the Retrorsichelidae Feldmann, Tshudy \& Thomson, 1993, previously included in Galatheoidea Samouelle, 1819 (Feldmann et al. 1993: figs 19, 20). (See below and Discussion).

\section{System of Luque et al. (unpublished)}

The preprint of Luque et al. (unpublished), on evolution of crab eye structures, first posted online Oct. 7, 2019, contains contradictory statements about the recently established Callichimaeroidea. In the preprint, this superfamily is treated as a podotreme lineage (Luque et al. unpublished: $22,23)$. This is the only level that is processed throughout the text, and only in the figure 16 of the same paper the section Callichimaeroida appears as a main brachyuran section, in addition to eight others, as in Luque et al. (2019). It is not clear whether the authors continue to recognise a distinct section, likewise in Luque et al. (2019), or have changed their minds and regard it as part of podotremes. About the Podotremata, Luque et al. (unpublished: fig. 4) write: "The main competing hypotheses suggest that either 'lower' true crabs, or podotremes form a monophyletic clade Podotremata [...]", whereas podotreme crabs may represent a paraphyletic grade of increasing complexity [...] with some intermediate groups closer to eubrachyurans than to other podotremes. The term "podotreme grade" is used in the same sense as in Luque et al. (2019).

It is beyond the scope of the present paper to evaluate all fossil taxa that have been referred to the Dromioidea, Homolodromioidea, Glaessneropsoidea and Konidromitoidea by Schweitzer et al. (2012a) and by subsequent authors. I shall restrict myself to a selection of extinct taxa of Jurassic and Early and mid-Cretaceous age that are considered possible candidates for my new assessment. These are presented below, arranged in families, listed in alphabetical order and according to the classificatory scheme in use to date.

Family ArCHAEOCHIAPASIDAE

Guinot, Carbot-Chanona \& Vega, 2019

(Fig. 1A-D)

Type Genus. - Archaeochiapasa Guinot, Carbot-Chanona \& Vega, 2019 (type species by original designation: $A$. mardoqueoi Guinot, Carbot-Chanona \& Vega, 2019).

\section{REMARKS}

Affinities with an extant eubrachyuran superfamily might be sought amongst the Majoidea Samouelle, 1819, particularly near the basal family Oregoniidae Garth, 1958 (Garth 1958), based on morphology, larval characters, spermatozoal traits and genetics. The extant Hyas coarctatus Leach, 1814 (Fig. 18A, B) has a lyrate carapace, with laterally dilated hepatic and postorbital regions forming an alate expansion and rather widened branchial regions; but P2 and P3 are not long and of significant stoutness whereas P5 is not reduced (Rathbun 1925: 252, fig. 93, pls 94, 95). Another extant oregoniid genus, Chionoecetes Kroyer, 1838, the species C. tanneri Rathbun, 1893 in particular (Fig. 18C), has many features in common with $A$. mardoqueoi, such as a quadrate carapace; unprotected eyes; broad and swollen branchial regions, with a deeply depressed interbranchial space; very long, compressed P2-P3; moderately long P4, and a significantly reduced P5 (Rathbun 1925: 232, 234, figs 88, 89, pls 84-91; Breton 2009: fig. 9). Thoracic sterna of Hyas coarctatus (Fig. 18B) (Rathbun 1925: pl. 95) and Chionoecetes spp. (Rathbun 1925: pls 85, 87, 89, 91) are very wide, albeit not as wide as in $A$. mardoqueoi (Fig. 1C), and pleons are quite distinctive. The similarities between the Archaeochiapasidae and extant Oregoniidae, a family that is primarily confined to boreal regions, are likely indicative of relationship and close affinities of Archaeochiapasidae with the Majoidea.

Fossil representatives of Oregoniidae are only known from the Eocene: Hyas aranaeus (Linnaeus, 1758), H. chippubetsuensis Kato, Nakashima \& Yanagisawa, 2014, H. meridionalis Glaessner, 1928, H. oranensis Van Straelen, 1936, H. $\tan \mathrm{Hu}, 1984, H$. tentokujiensis Kato, Nakashima \& Yanagisawa, 2014, H. tsuchidai Imaizumi, 1952 (Imaizumi 1952; Kato et al. 2014); and Oregonia spinifera Schweitzer, Feldmann, Gonzáles-Barba \& Vega, 2002 (Schweitzer et al. 2002).

It would be of interest to compare Archaeochiapasa with species of Mithracia Bell, 1858 (type species: M. libinoides Bell, 1858), such as the Middle Eocene Mithracia margaritifera Beschin, Busulini, De Angeli \& Tessier, 1994 (Beschin et al. 1994: fig. 5, pl. 6, fig. 2a-c) whose carapace shape is reminiscent of that of Hyas (Fig. 18A). 

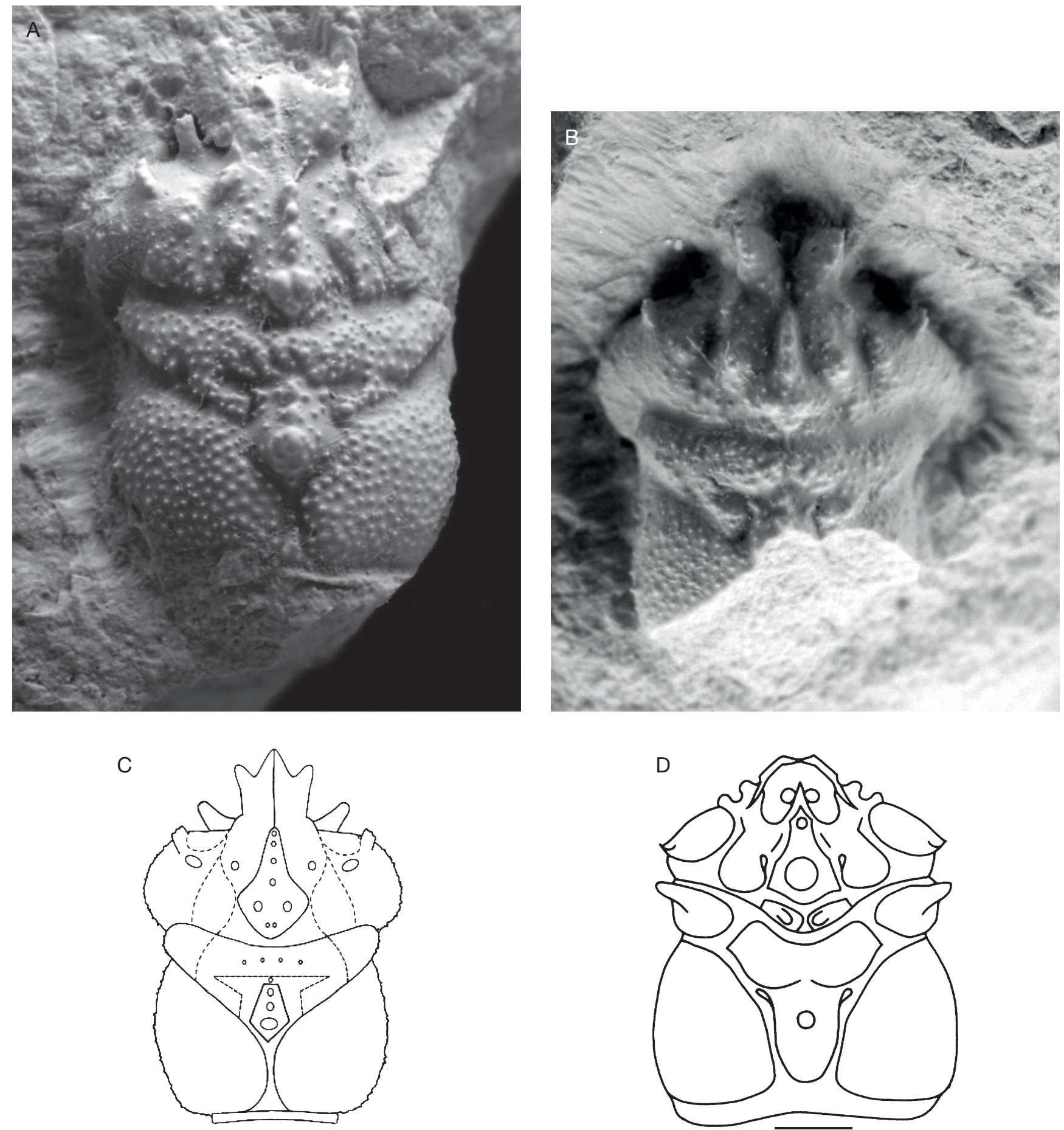

FIG. 2. - Bucculentidae Schweitzer \& Feldmann, 2009: A-C, Bucculentum bucculentum (Wehner, 1988); A, holotype, Germany, Biburg bei Weissenburg, Oxfordian (BSP 1980 XXX 1255); B, anterior portion of carapace, Germany, Unterwilflingen, Kimmeridgian (BSP 1987 I 55) (Wehner 1988: pl. 4, figs 1 and 6, respectively, as Nodoprosopon bucculentum); C, groundplan of carapace (after Starzyk et al. 2011: fig. 2 in Neues Jahrbuch für Geologie und Paläontologie Abhandlungen 260: http://www.schweizerbart.de/journals/njgpa); D, Wilmingtonia satyrica Wright \& Collins, 1972: reconstitution of carapace, Devon, Wilmington, Cenomanian (after Wright \& Collins 1972: fig. 2a). Scale bar: D, $10 \mathrm{~mm}$.

Family BuCCULENTIDAE Schweitzer \& Feldmann, 2009 (Fig. 2A-D)

TYPE GENUS. - Bucculentum Schweitzer \& Feldmann, 2009 (type species by original designation: Nodoprosopon bucculentum Wehner, 1988 (Wehner 1988: fig. 15, pl. 4, figs 1, 2, 6), from the
Oxfordian and Kimmeridgian [Upper Jurassic]). Other species: Bucculentum bachmayeri Schweitzer \& Feldmann, 2009, from the Tithonian (Upper Jurassic).

InCLUDED GENERA. - Wilmingtonia Wright \& Collins, 1972 (type species: W. satyrica Wright \& Collins, 1972, from the Upper Cretaceous [Cenomanian]). 


\section{REMARKS}

This family is currently assigned to the superfamily Homolodromioidea (Schweitzer \& Feldmann 2009a: 78, fig. 3.3, 3.4; Karasawa et al. 2011: 535; Schweitzer et al. 2012a: fig. 2; Starzyk et al. 2011: 207, figs 1-3). Its representatives, formerly included in the Prosopidae (Wehner 1988; Müller et al. 2000), may be diagnosed using the following characters: dorsal surface separated into numerous regions; hepatic regions massively inflated; rostrum projected and depressed axially; cervical and strongly oblique branchiocardiac grooves deeply marked; orbit highly developed; orbital area situated on dorsal carapace or subdorsally on hepatic region, and inclined to the dorsal side; slightly concave posterior margin of carapace forming a short rim (rim widest at lateral edges in $B$. bachmayeri); cardiac region more or less extending to posterior margin between large branchial regions. An additional groove joins the middle of the dorsal portion of the orbital area to the cervical groove (Krzemińska et al. 2019: fig. 1).

The photographs and carapace reconstitutions of Bucculentum bucculentum (Wehner 1988: fig. 15, pl. 4, figs 1, 2, 6, as Nodoprosopon bucculentum) (Fig. 2A, B) and the carapace reconstitutions of Wilmingtonia satyrica (Wright \& Collins 1972: fig. 2; Müller et al. 2000: fig. 10) (Fig. 2D here), as well as the bucculentid groundplan by Starzyk et al. (2011: fig. 1) (Fig. 2C here) clearly illustrate the short, rimmed posterior border, which is represented by a conspicuously straight thickening by Starzyk et al. (2011: fig. 1) and Krzemińska et al. 2019: fig. 1C, D). The first pleonal somite is preserved dorsally in several specimens of B. bucculentum (Starzyk et al. 2011: fig. 4F).

All species of bucculentid are small. Available specimens of the Late Jurassic Bucculentum bucculentum and B. bachmayeri measure 4.51-10.75 mm cl (Starzyk et al. 2011: 207, fig. 3, table 2), and the holotype of the Cenomanian Wilmingtonia satyrica is small as well (Wright \& Collins 1972: 20, fig. 2, pl. 1, figs 5, 6; Schweitzer et al. 2012a: fig. 2.2a).

The Bucculentidae (Fig. 2A-D), a monophyletic extinct family, to which the Nodoprosopidae Schweitzer \& Feldmann, 2009 (Schweitzer \& Feldmann 2009a) shows striking similarities, could rank amongst the putative eubrachyurans (see Discussion below).

\section{Family DromiIDAE \\ De Haan, 1833}

Many extinct taxa now assigned to the Homolodromioidea appear, in fact, to be dromioids (within the Dynomeniformia); see details below. In both superfamilies (except for the Dynomenidae), reduced, dorsal, moveable and specalised P4 and P5 are used to carry foreign materials that provide a variety of possible benefits, including camouflage and protection from predators (Guinot \& Wicksten 2015).

\section{Subfamily BASINOTOPINAE \\ Karasawa, Schweitzer \& Feldmann, 2011}

(Fig. 3)

Type Genus. - Basinotopus M'Coy, 1849 (type species by monotypy: Inachus lamarckii Desmarest, 1822, from the Eocene; see M'Coy 1849: 167-169, unnumbered figure on p. 167).

INCLUDED GENERA. - Lucanthonisia Van Bakel, Artal, Fraaije \& Jagt, 2008 (type species by original designation: L. praemia Van Bakel, Artal, Fraaije \& Jagt, 2008, from the Lower Oligocene; see Van Bakel et al. 2009).

\section{REMARKS}

The Basinotopidae of Karasawa et al. (2011) was downgraded to subfamilial rank within the Dromiidae, to correspond to the level of the Sphaerodromiinae (Guinot et al. 2013). Carapaces of B. lamarckii (Fig. 3) and L. praemia are fairly similar, with well-delimited cephalic and scapular arches, but the preserved portion of the sternal plate of L. praemia (see Van Bakel et al. 2009: fig. 3D) appears to differ from the narrower sternites of $B$. lamarckii, as illustrated by Karasawa et al. (2011: fig. 4D, F; see also Schweitzer et al. 2012a: fig. 1c).

\section{Subfamily DrominaE \\ De Haan, 1833}

(Fig. 4A-C)

TyPE GENUS. - Dromia Weber, 1795 (type species by subsequent designation of ICZN [1964], Opinion 688: Cancer personatus Linnaeus, 1758).

INCLUDED GENERA. - For extant genera, reference is made to McLay (1993, 2001) and Guinot \& Tavares (2003); fossil taxa have been listed and illustrated by Franțescu et al. (2010), Karasawa et al. (2011: 542) and Schweitzer et al.' (2012a: figs 19, 20).

\section{REMARKS}

Currently, in excess of 35 extant genera are recognised (McLay 1993). Extinct dromiines are rather rare, apparently first occurring during the Late Cretaceous, from the Maastrichtian (see Feldmann \& Schweitzer 2019). I am not aware of any earlier representatives. Carapace shape varies widely in extant genera, ranging from long and narrow (rarely), such as in Ascidiophilus caphyraeformis Richters, 1880 (Fig. 4B, C; a species living in association with ascidians, see Guinot \& Wicksten 2015: fig. 71-11.3G), to wide and rounded (Fig. 4A), occasionally subquadrangular or subpentagonal, and unusual as in the (probably) shell-carrying genus Desmodromia McLay, 2001 (McLay 2001).

The assignment of Dromiopsis Reuss, 1858 (type species by subsequent designation of Beurlen [1928]: Brachyurites rugosus von Schlotheim, 1820) to the Dromiinae appears doubtful, and its inclusion in the Dynomenidae is less questionable or seems acceptable (Jagt et al. 2014a, 2015; Robin et al. 2017; Nyborg et al. 2019). 


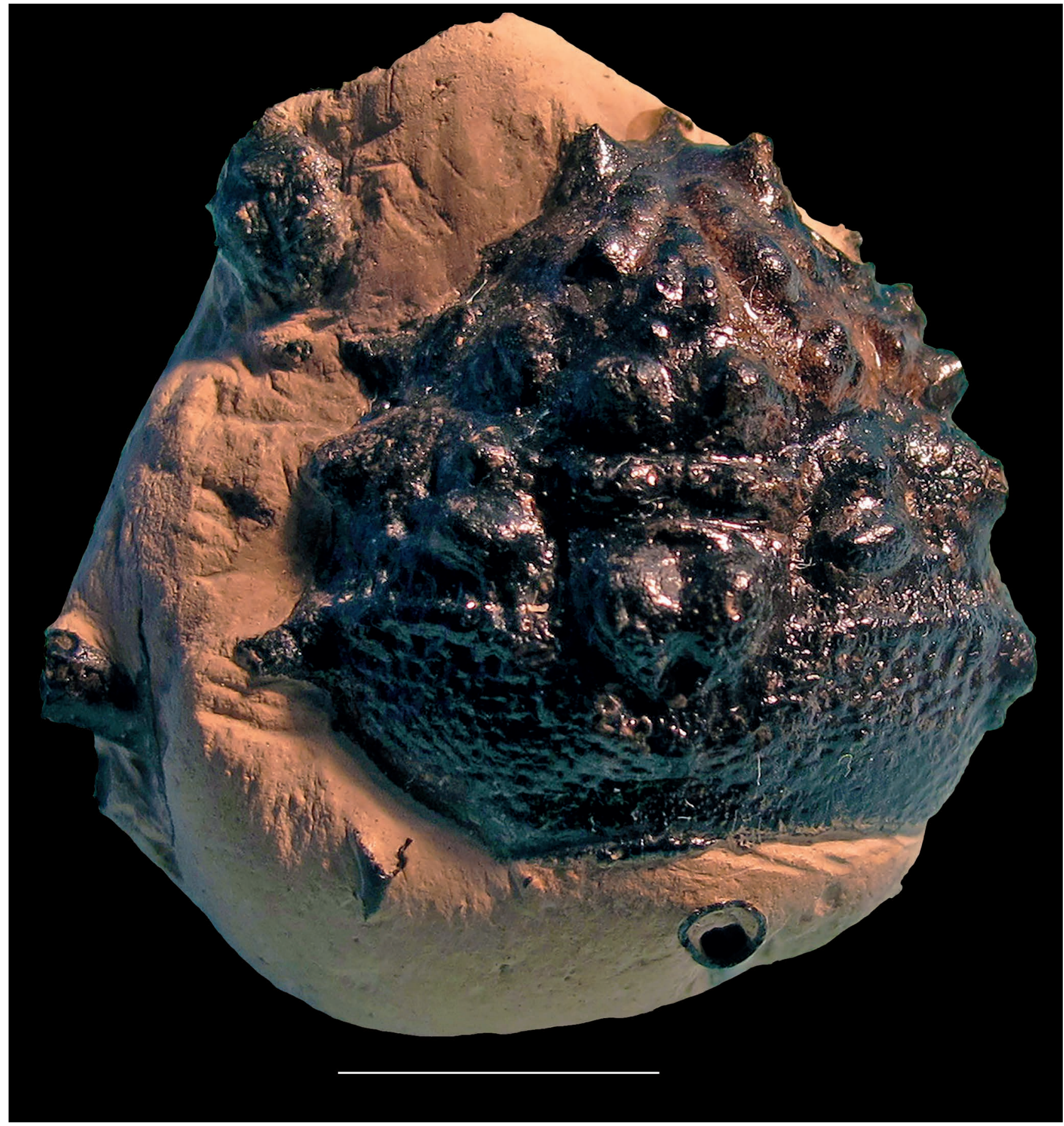

FIG. 3. - Basinotopinae Karasawa, Schweitzer \& Feldmann, 2011 (Dromiidae De Haan, 1833). Basinotopus lamarckii Desmarest, 1822, U.K., Kent, Isle of Sheppey, London Clay Formation, Ypresian (lower Eocene) (C-044-2, Àlex Ossó private collection). Photograph courtesy of Àlex Ossó (Tarragona). Scale bar: $10 \mathrm{~mm}$.

Subfamily GoniodromitinaE Beurlen, 1932 (Fig. 5A-E)

TYPE GENUS. - Goniodromites Reuss, 1858 (type species by subsequent designation of Glaessner [1929]: G. bidentatus Reuss, 1858).

INCLUDED GENERA. - Cycloprosopon Lőrenthey in Lőrenthey \& Beurlen, 1929 (type species by original designation: Pithonoton
[Cycloprosopon] typicum Lőrenthey in Lőrenthey \& Beurlen, 1929); Eodromites Patrulius, 1959 (type species by original designation: Prosopon grande von Meyer, 1857); Pithonoton von Meyer, 1842 (type species by subsequent designation of Glaessner 1929: Prosopon marginatum von Meyer, 1842); Plagiophthalmus Bell, 1863 (type species by monotypy: P. oviformis Bell, 1863 [Fig. 5A]); Sabellidromites Schweitzer \& Feldmann, 2008 (type species by original designation: Goniodromites scarabaeus Wright \& Wright, 1950 [Fig. 5C]). 


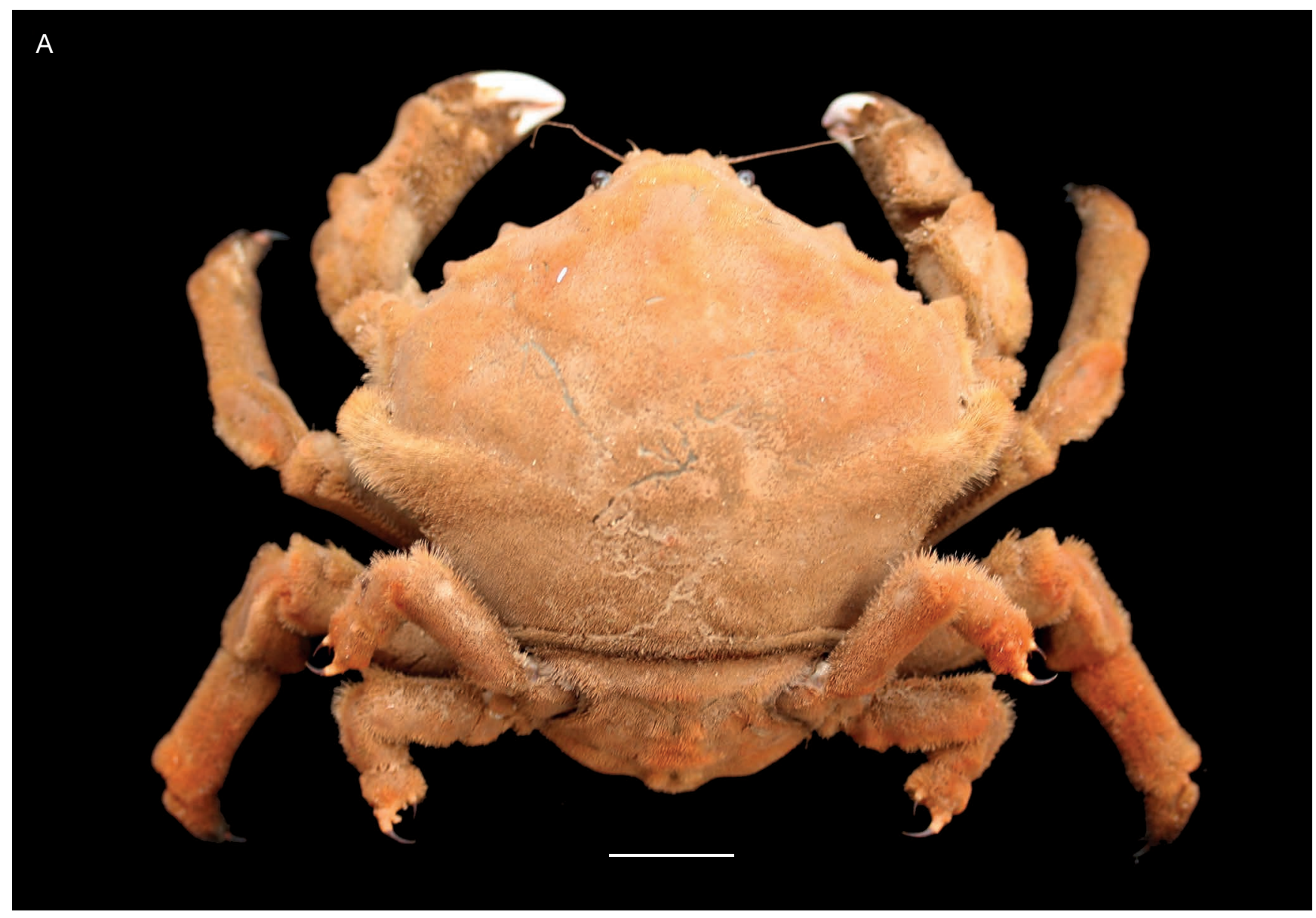

B

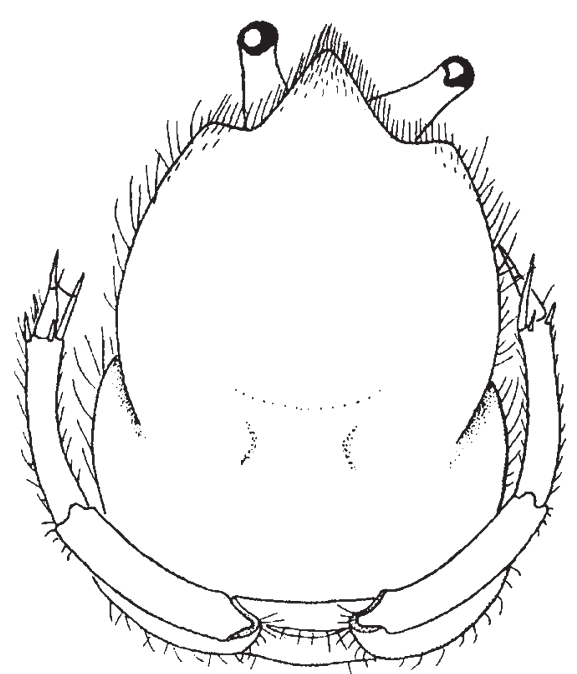

C

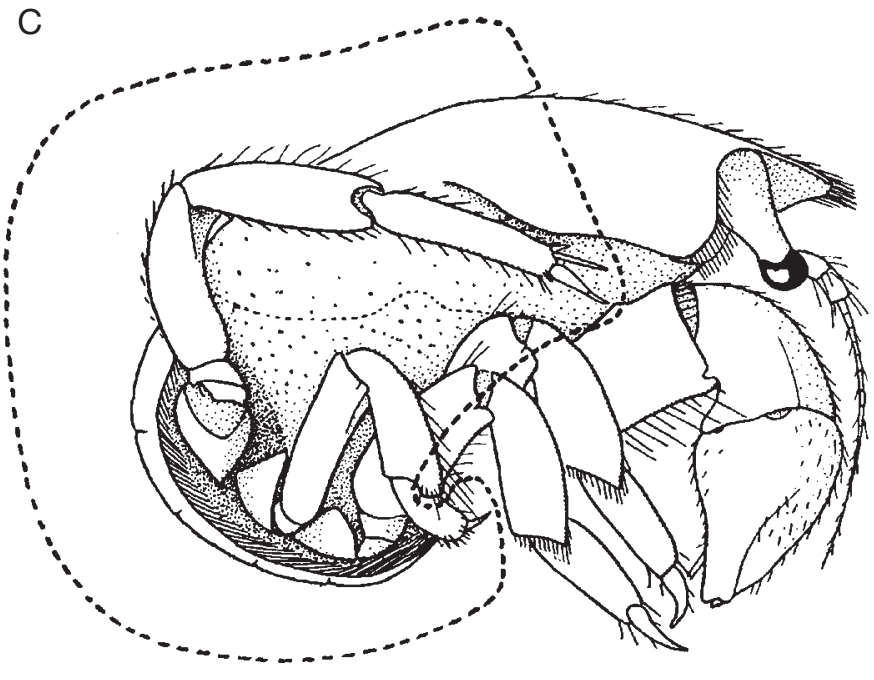

FIG. 4. - Extant Dromiinae De Haan, 1833 (Dromiidae De Haan, 1833): A, Tumidodromia dormia (Linnaeus, 1763), Mayotte, Recif La Prévoyante, Expedition KUW 2009, stn 12b, 6-12 m: female 87,5 × 106 mm (MNHN-IU-2009-1157 = MNHN-B32384). Photograph courtesy of J. Poupin; B, C, Ascidiophilus caphyraeformis Richters, 1880 , female $6.0 \times 4,5 \mathrm{~mm}$, with elongate carapace and pereiopods lodged in concave flanks of carapace, P4 reduced; B, dorsal view; C, lateral view of the crab in its compound ascidian represented by broken line (after Gordon 1950: figs 6A, 4A, respectively, as Pseudodromia murrayi Gordon, 1950). Scale bar: $\mathrm{A}, 2 \mathrm{~cm}$.

REMARKS

I do not agree with the family status of the Goniodromitidae and placement in the superfamily Homolodromioidea, as subscribed to by most authors (Van Straelen 1925; Schweitzer et al.
2007, 2009, 2012a, 2018a; Schweitzer \& Feldmann 2008a; De Grave et al. 2009; Karasawa et al. 2011; Franțescu 2011; Klompmaker et al. 2012; Feldmann et al. 2013; Starzyk et al. 2012, 2015b; Hyžný et al. 2015). Instead, I favour assignment 

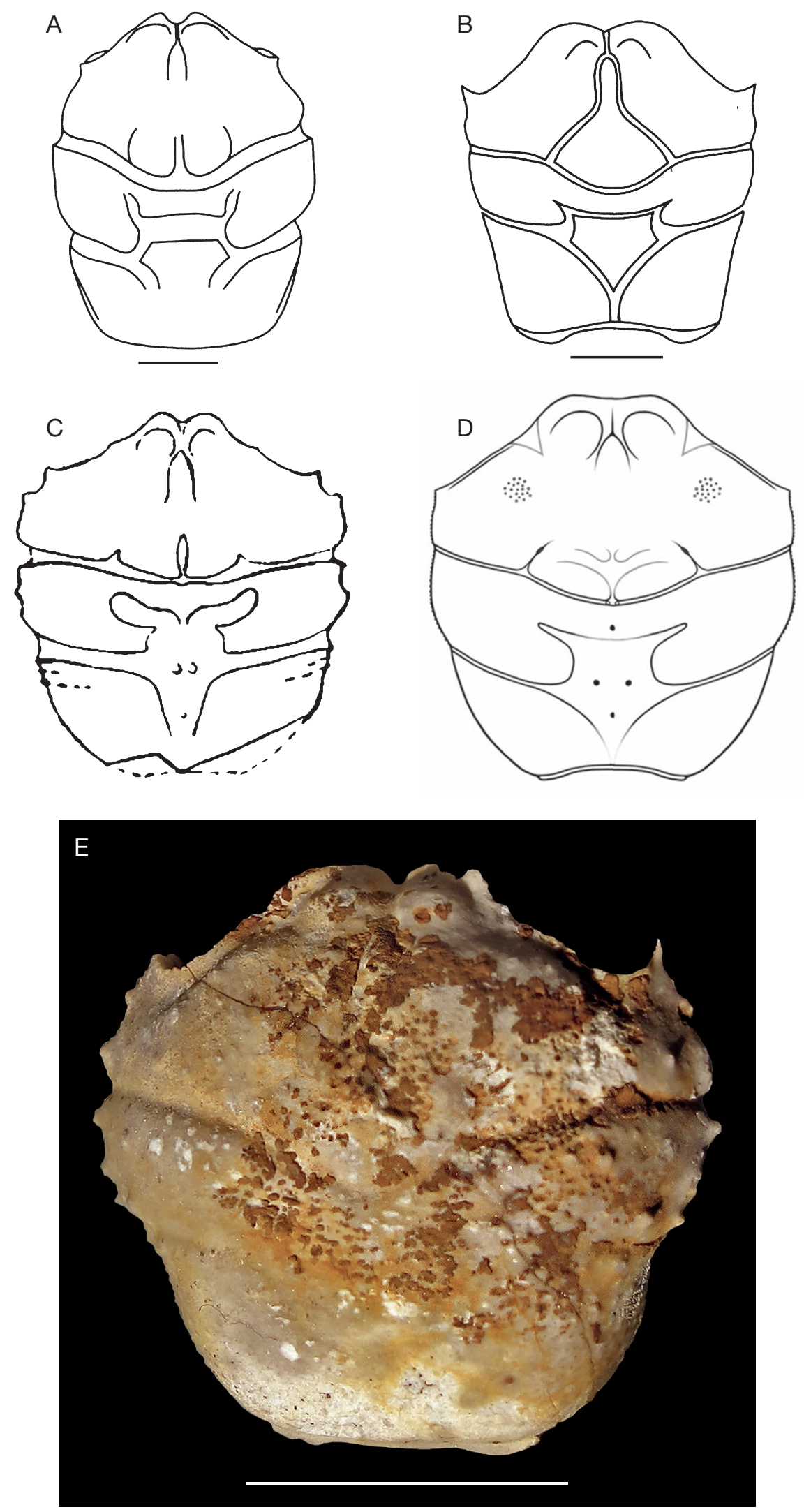

FIG. 5. - Species assigned to Goniodromitinae Beurlen, 1932: A, Plagiophthalmus oviformis (Bell, 1863), England, Wilmington, Devon, Cenomanian (after Wright \& Wright 1950: fig. 1a); B, Pithonoton marginatum (von Meyer, 1842) (after Müller et al. 2000: fig. 12a); C, Sabellidromites scarabaeus (Wright \& Wright, 1950), paratype, internal cast, England, Leighton Buzzard, Lower Albian (after Wright \& Wright 1950: fig. 4, as Goniodromites scarabaeus); D, Eodromites grandis (von Meyer, 1857) (after Starzyk 2015b: fig. 2.2, courtesy of Palaeontologia Electronica); E, Goniodromites laevis (Van Straelen, 1940), Spain, Navarra, Koskobilo quarry, Olzazti, upper Albian (C-171-2, Àlex Ossó private collection). Photograph courtesy of Àlex Ossó (Tarragona). Scale bars: A, 5 mm; B, 4 mm; E, 10 mm. 
to the Dromioidea (similarly to Wright \& Wright 1950), probably within the Dromiidae, and at a subfamily rank, Goniodromitinae (which takes priority over the Pithonotinae Glaessner, 1933; see Wehner 1988), as proposed previously by Ossó et al. (2018).

The Goniodromitinae, which in its current composition comprises numerous and highly diverse genera (see Jagt et al. 2015), with a large number of species placed either in Goniodromites or Pithonoton (see Feldmann et al. 2006; Schweitzer \& Feldmann 2008a: tables 1,2), appears paraphyletic (see Ossó et al. 2018: 102, figs 9, 10), which means that all genera and species must be re-examined, with a re-evaluation of their taxonomic placement.

Goniodromites bidentatus and $G$. aff. bidentatus have been figured by Patrulius (1966: pl. 31, figs 19, 20) and Franțescu (2011: 279, fig. 7), respectively. Differences between various species of Goniodromites have been detailed by Hyžný et al. (2015: 638, figs 4, 5, 8C, D, table 2). About Pithonoton incisum (Van Straelen, 1925, as Goniodromites) reference is made to Krobicki \& Zaton (2016: 705). A moult of G. laevis, with a partial ventral surface preserved, but without the thoracic sternum, has recently been published by Klompmaker et al. (2016: fig. 3D-G) (Fig. 5E). Eodromites Patrulius, 1959 (Fig. 5D) (which is abundant at many localities with outcrops of Jurassic rocks and considered a homolodromiid (Schweitzer \& Feldmann 2010c; Schweigert \& Koppka 2011; Franțescu 2011: 283, fig. 9; Klompmaker et al. 2012), has recently been revised in notable detail by Starzyk (2015b: figs 1-8), who referred to new diagnostic features (see also Starzyk \& Krzemińska 2019: fig. 1B). A new description and new figures of the type species of Eodromites, E. grandis, were provided by Hyžný et al. (2015: figs 6, 8E).

Pithonoton cardwelli Armstrong, Nyborg, Bishop, Ossó-Morales \& Vega, 2009, with a preserved thoracic sternum (Armstrong et al. 2009: fig. 3.10), was placed in the Sphaerodromiidae by Schweitzer \& Feldmann (2012b), considered a questionable Dromilites by Van Bakel et al. (2017), and then reassigned to Pithonoton by Ossó et al. (2018). Pithonoton richardsoni Woodward, 1907, from the Bajocian (see Withers 1951: figs 1-3, pl. 15, figs 1-6), has been referred to Tanidromites Schweitzer \& Feldmann, 2008 (Schweitzer \& Feldmann 2008a) (see Schweigert \& Koppka 2011: fig. 5; Krobicki \& Zatoń 2016: 707, fig. 6C, table 1).

Cyclothyreus Remeš, 1895 (type species by monotypy: C. strambergensis), which had already been assumed to have dynomenid affinities (Schweitzer \& Feldmann 2009d), was transferred to the Dynomenidae by Van Bakel et al. (2012a) as a member of the subfamily Graptocarcininae Van Bakel, Guinot, Corral \& Artal, 2012. Species now included in this genus, still assigned to the Goniodromitidae by Schweitzer et al. (2018b: fig. 6), may also turn out to be graptocarcinines.

The allocation of Costadromia hajzeri Feldmann \& Schweitzer, 2019 (Feldmann \& Schweitzer 2019), from the Campanian, to the Dromiidae should also be reassessed. Another example is Palaeodromites A. Milne-Edwards, 1865 (type species by monotypy: P. octodentatus A. Milne-Edwards, 1865), which was placed in the Dynomenidae by Jagt et al.
(2007). Any interpretation of this genus is fraught with difficulties because all basal families of the Dynomeniformia share similar plesiomorphies, hence there is always the risk of confusion. According to well-established data, that taxa share the same plesiomorphic trait state in fact cannot reveal anything about the relationships; only apomorphic characters (innovation, that sets the clade apart from other clades) allow differentiation (Hennig 1966).

Of note is the genus Distefania Checchia-Rispoli, 1917 (Fig. 6B-D) (type species by original designation: Cyphonotus incertus Bell, 1863, from the Cenomanian, see Schweitzer et al. [2012a]). Schweitzer \& Feldmann (2010b) and Jagt et al. (2014b) listed Distefania himeraensis Checchia-Rispoli, 1917 as type species. To date, a moult of Distefania incerta with a partially preserved ventral surface, yet without the thoracic sternum, has been illustrated (Klompmaker et al. 2016: fig. 3A-C). Relationships of this genus may be sought in the Sphaerodromiinae.

This example of Goniodromitinae clearly illustrates the potential confusion amongst primitive brachyurans, and the composition of this subfamily calls for a revision.

\section{Subfamily HyPOCONCHINAE Guinot \& Tavares, 2003}

TYPE GENUS. - Hypoconcha Guérin-Méneville, 1854 (type species: Cancer parasiticus Linnaeus, 1763, a senior synonym of Cancer sabulosus Herbst, 1799, see Holthuis [1962]). See Guinot \& Tavares (2003: 97, figs 19, 20, 28K).

INCLUDED GENERA. - No other included genera, nor fossil representatives.

\section{REMARKS}

The soft and even membranous surface of the hypoconchines, usually referred to as "shell-carrying crabs as they live perfectly concealed under large and heavy shells carried by P4 and P5 (Guinot \& Wicksten 2015: fig. 71-11.3H), explains the low fossilisation potential and their absence from the fossil record.

\section{Subfamily Sphaerodrominae Guinot \& Tavares, 2003} (Fig. 6A-D)

TYPE GENUS. - Sphaerodromia Alcock, 1899 (type species by monotypy: Dromidia kendalli Alcock \& Anderson, 1894). See Guinot \& Tavares (2003: 102, figs 21-24, 28E-G).

InCLUDED GENERA (pro parte). - Distefania Checchia-Rispoli, 1917 (type species by original designation: Cyphonotus incertus Bell, 1863, from the Cenomanian); Eodromia McLay, 1993 (type species by original designation: E. denticulata McLay, 1993); ? Ferricorda Schweitzer \& Feldmann, 2010 (type species by original designation: Dromiopsis kimberleyae Bishop, 1987).

\section{REMARKS}

Elevation to family rank of the Sphaerodromiinae by Schweitzer \& Feldmann (2010d), a decision adopted by Karasawa et al. (2011), Schweitzer \& Feldmann (2012a, b) and Schweitzer et al. (2012a), is not supported by any putative 


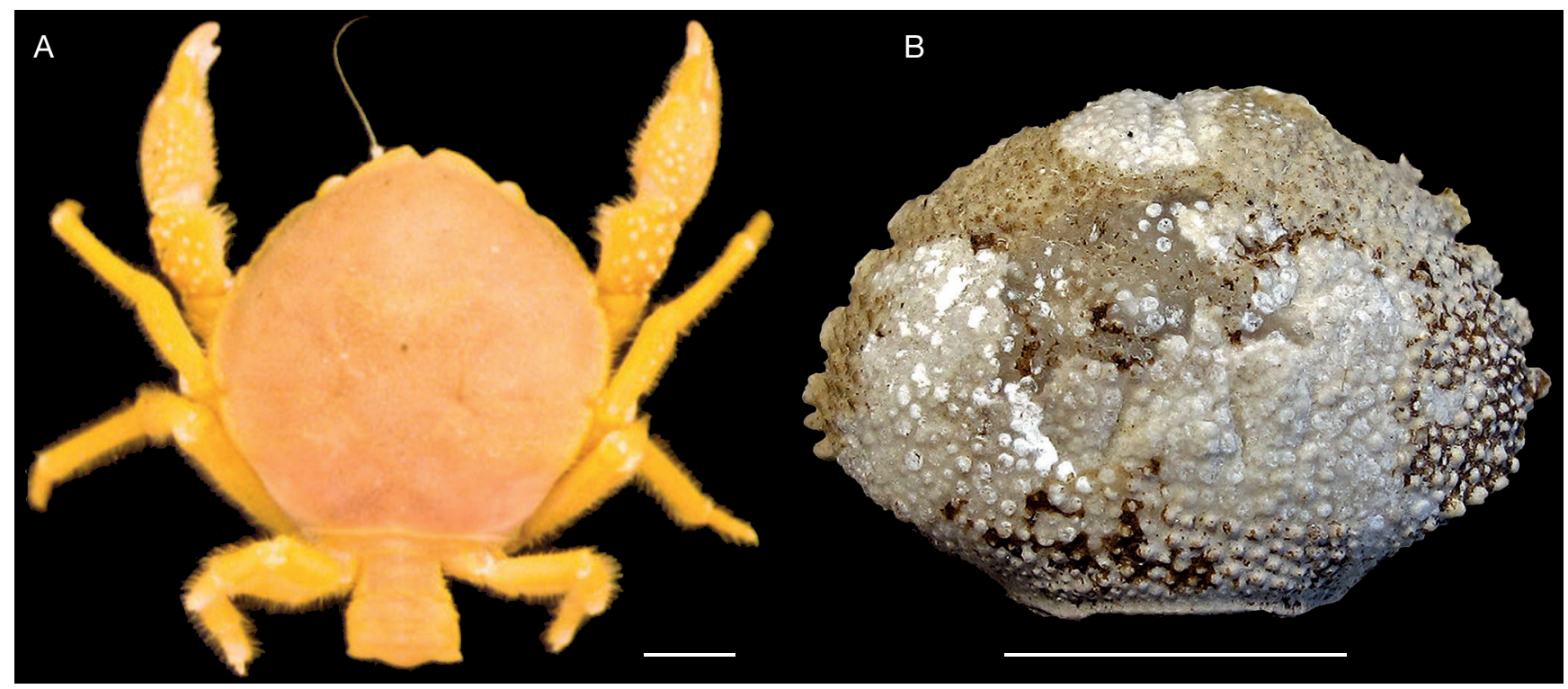

C

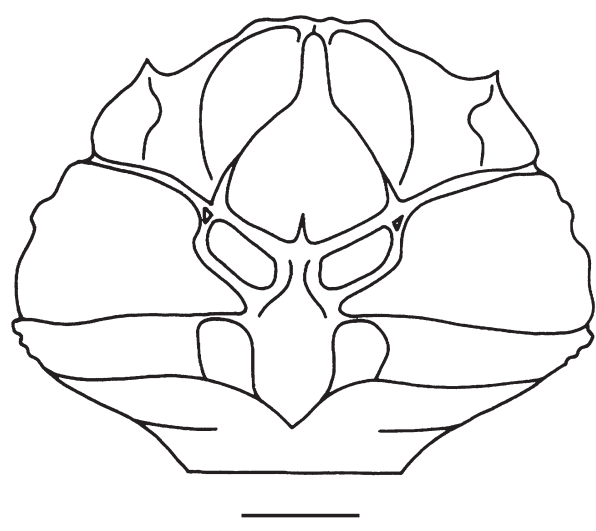

D

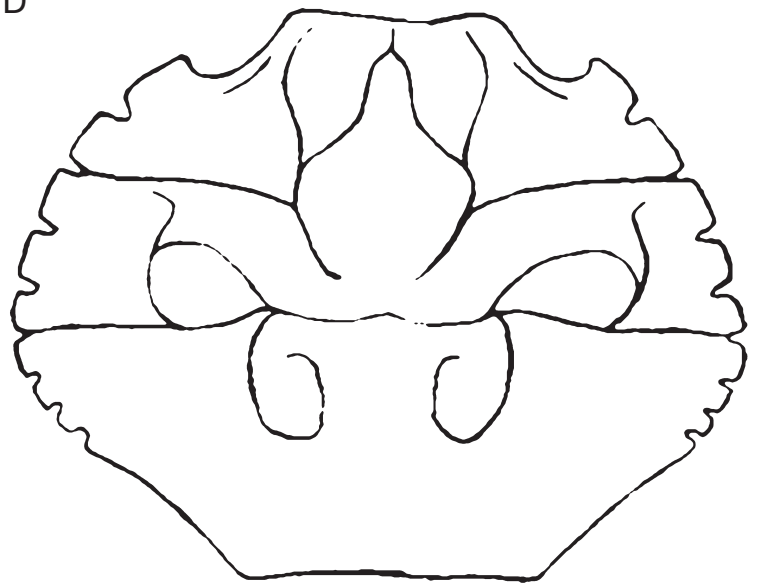

FIG. 6. - Sphaerodromiinae Guinot \& Tavares, 2003: A, Sphaerodromia ducoussoi McLay, 1991, (extant), Tuamotu, Tuanake atoll, SMCB cruise, stn CAS253, 450 m: holotype, male 43.2 × 43 mm, MNHN-IU-2008-11179 (= MNHN-B22172), photograph courtesy of J. Poupin; B-D, Distefania incerta (Bell, 1863); B, Spain, Navarra, Koskobilo quarry, Olazti, Late Albian (C-029-2, Àlex Ossó private collection), photograph by Àlex Ossó and courtesy of À. Ossó; C, D, reconstitutions of carapaces; C, holotype, England, Horningsham, Wiltshire, Cenomanian (after Wright \& Wright 1950: fig. 7a, as Cyphonotus incertus); D, diagrammatic figure of holotype of Cyphonotus himerensis [sic] Checchia-Rispoli, 1917, holotype, Sicilia, Himera, Cenomanian (after Wright \& Wright 1950: fig. 11). Scale bars: A, B, $1 \mathrm{~cm}$; C, $5 \mathrm{~mm}$.

familial level of generality; instead, a less inclusive subfamily rank, in comparison with the Dromiinae and Hypoconchinae, is needed here.

The five known extant sphaerodromiines, Sphaerodromia brizops McLay \& Crosnier, 1991, S. ducoussoi McLay, 1991 (Fig. 6A), S. lamellata Crosnier, 1994, S. nux Alcock, 1899 (all three being diverse and relatively large, with $\mathrm{cw}>65 \mathrm{~mm}$ ), and Eodromia denticulata (a very small species, with ovigerous females measuring only $4.5 \mathrm{~mm}$ in $\mathrm{cw}$ ), share plesiomorphic characters (e.g. vestigial pleopods, sometimes biramous, on somites 3-5; sternal sutures 7/8 short; G2 with expodite; male P5 coxa modified prolonged into hard process enclosing penis). The subfamily has been interpreted as basal within the Dromiidae (McLay 1993) and is assumed to have branched off from the Dromiidae early (Guinot \& Tavares 2003). Carapaces of their members are either narrow or broad, more or less globose, without well-defined regions and grooves, and with a marked posterior notch on the lateral margins.

It is likely that a much larger number of fossil species will have to be referred to the Sphaerodromiinae, the most basal dromiids. Such is the case with, for example, Distefania Checchia-Rispoli, 1917, so far assigned to the Goniodromitidae (Schweitzer \& Feldmann 2010b: figs 1-3; Schweitzer et al. 2012a: fig. 3a, b; Klompmaker et al. 2012, 2016; Jagt et al. 2015). The type species, D. incerta (Fig. 6B-D), from the Cenomanian, is a fairly large crab. Costadromia hajzeri Feldmann \& Schweitzer, 2019, from the Campanian Wenonah Formation in New Jersey, assigned to the Dromiidae by Feldmann \& Schweitzer (2019), seems referrable to the Sphaerodrominae.

A carapace of Ferricorda kimberleyae (see Bishop 1987: figs 1, 2, as Dromiopsis kimberleyae; Schweitzer et al. 2012a: 
fig. 22.2A-C) was found preserved in association with its pereiopods inside a phragmocone chamber of a baculitid ammonite from the lower Campanian (Landman et al. 2014: fig. 4). It shows a pentagonal-circular, deeply grooved carapace, with a clear demarcation between the cephalic and scapular arches [as illustrated for Basinotopus lamarckii by M'Coy (1849: figure on p. 67); Fig. 3], P4 and P5 shorter than P2 and P3, and dorsal first pleonal somites. Considered a dynomenid, it could rather be a dromiid, probably a sphaerodromiine.

The two Eocene species of Dromilites H. Milne Edwards in Bell (1858), i.e., the type species D. bucklandii H. Milne Edwards, 1837 (senior synonym of Dromilites simplex Quayle \& Collins, 1981) and D. belli Van Bakel, Robin, Charbonnier \& Saward, 2017, show strongly swollen regions and marked grooves on carapaces. Recently, Van Bakel et al. (2017) have included these in the Sphaerodromiinae. D. montenati Robin, Van Bakel, Pacaud \& Charbonnier, 2017, from the Danian, the oldest record of the genus, was also assigned to the Sphaerodromiinae (Robin et al. 2017). Of Dromilites belli ventral characters (pleon, telson, uropods, and part of the thoracic sternum; see Van Bakel et al. 2017: figs 2, 3) are known; these show plesiomorphic characters that are actually shared by dromiines and sphaerodromiines. The recognition of groups that are not supported by apomorphies is fraught with difficulties.

Family EOCARCINIDAE Withers, 1932

See below under Homolodromiidae Alcock, 1900.

Family GLAessneropsidAe Patrulius, 1959 (Fig. 7A-D)

TyPe GEnUs. - Glaessneropsis Patrulius, 1959 (type species by original designation: Prosopon heraldicum Moericke, 1889, from the Upper Jurassic [Tithonian]).

INCLUDED GENERA (according to Schweitzer et al. 2012a). — Ekalakia Bishop, 1976, from Upper Cretaceous (Campanian-Maastrichtian): (type species by original designation: E. lamberti Bishop, 1976); Rathbunopon Stenzel, 1945, from the Lower (Aptian) to Upper Cretaceous (Cenomanian): (type species by original designation: $R$. polyakron Stenzel, 1945); Vectis Withers, 1946, from the Lower Cretaceous (Aptian-Albian) (type species by original designation: V. wrighti Withers, 1946); Verrucarcinus Schweitzer \& Feldmann, 2009 (type species by original designation: Prosopon torosum von Meyer, 1857).

\section{REMARKS}

By inclusion of the above-mentioned genera, the family (placed in the superfamily Glaessneropsoidea; see Schweitzer et al. 2012a) appears to be paraphyletic, with some species showing markedly inflated subhepatic regions, deep grooves and a depressed flange at the posterior margin of the carapace.

Glaessneropsis heraldica (Fig. 7A-C), with a spatulate, keeled rostrum that extends well beyond the orbits, shows a slightly concave or straight carapace posterior margin that is rimmed (Feldmann et al. 2008: fig. 1.3; Schweitzer \& Feldmann 2009a: fig. 4.1; Schweitzer et al. 2012a: fig. 13.1).
The carapace of Ekalakia lamberti (Fig. 7D), which shows a "flaring rectangular anterior", a "shelf-like posterior", a very faint groove along the rather straight and rimmed posterior margin, was considered close to Wilmingtonia (Bishop 1976: 399, 400, fig. 1, pl. 1) (Fig. 2D). Ekalakia lamberti, a small-sized species, has extremely large eyes adjacent to the rostrum and exposed over most of their surface, being surrounded on both sides by a prominent orbital rim (Feldmann et al. 2008: figs 1.1, 2, 4-10; Schweitzer et al. 2012a: fig. 13.2a-c). According to Tucker et al. (1987: 280-281, fig. 4 - and not fig. 2), although the morphology of their material of North Dakota "causes this specimen to resemble the majids", it is conservatively referred to E. lamberti. Glaessneropsis, Ekalakia and Wilmingtonia could rank amongst the presumed eubrachyurans as here recognised (see Discussion below).

The Early Cretaceous Vectis, with both small- and larger-sized species, was initially assigned to the Prosopidae and subsequently to the Glaessneropsidae (Schweitzer et al. 2012a: fig. 14.1a-c). In fact, it might not be a podotreme crab at all. The "well-marked depression in front of the posterior margin [that] delimits an unusually large border area" of Vectis wrighti (Fig. 8A) (Wright \& Collins 1972: 19, pl. 1, fig. 1a), also described as "biconvex" and well visible in the reconstitution of the carapace by Glaessner (1969: fig. 296.1a; see also Müller et al. 2000: fig. 8a), amongst other characters, suggests that it could be a eubrachyuran (see Discussion below).

The status of the genus Rathbunopon (Fig. 8B, C), which comprises only small-sized species, has been controversial. Initially assigned to the Prosopidae (Withers 1951; Wright \& Collins 1972), it has been alternatively regarded as a member of two distinct families and superfamilies, namely the Prosopidae within the Homolodromioidea (Klompmaker et al. 2011a: 195; Ossó et al. 2018: 97) and the Glaessneropsidae within the Glaessneropsoidea (Schweitzer \& Feldmann 2009a; Schweitzer et al. 2012a, 2018b). A striking feature of Rathbunopon is the deep, wide channel that extends along the entire posterior margin of the carapace, which is convex (Klompmaker et al. 2011a: 195, figs 3-6). A "strong groove" in front of the posterior margin is well visible in the excellent photographs of Rathbunopon obesum (Van Straelen, 1944) by Klompmaker et al. (2011a: 195, fig. 4), who listed the terminology of the regions, but failed to supply a specific name for this area. A "smooth ribbon between metabranchial and intestinal regions and the posterior rim" is found in $R$. tarraconensis Ossó, Van Bakel, Ferratges-Kwekel \& Moreno-Bedmara, 2018 (Ossó et al. 2018: 99, figs 7, 8). Although we cannot be sure of any homology with the flange of the Archaeochiapasidae (Fig. 1B, $\mathrm{D})$, the convergence is obvious. The ovoid carapace shape, the triangular rostrum, the well-defined and elevated regions, notably the metagastric and urogastric that are parallel and linear, as well as the deep and wide grooves set Rathbunopon apart. The convex posterior margin is not podotreme in nature; it begs the question of a possible eubrachyuran affiliation (see Discussion below).

Verrucarcinus (see Schweitzer \& Feldmann 2009a: 89, fig. 5; Schweitzer et al. 2012a: fig. 14.2; Franțescu 2011: 289, fig. 13), from the Upper Jurassic, shows a near-straight posterior margin of the carapace, with a broad depressed rim; this genus is currently under study. 

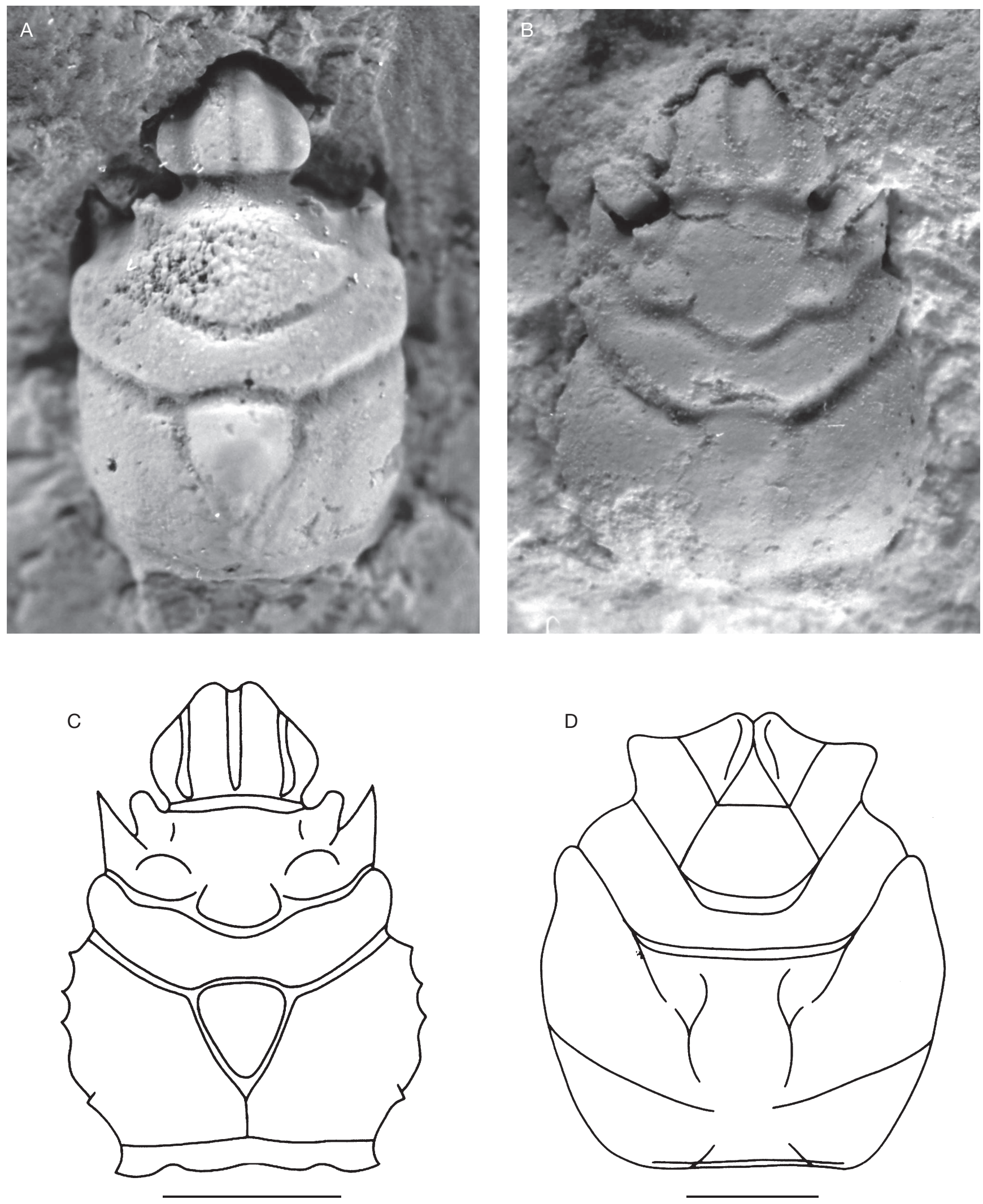

FIG. 7. - Glaessneropsoidea Patrulius, 1959, Glaessneropsidae Patrulius, 1959: A-C, Glaessneropsis heraldica (Moericke, 1889); A, holotype, original specimen of Moericke (1889: pl. 6, fig. 13), Moravia, Koniakau, upper Tithonian (BSP-AS III 306) (after Wehner 1988: pl. 8, fig. 1); B, Germany, Saal by Kelheim, Kimmeridgian (SYL-Nr. 6) (after Wehner 1988: pl. 8, fig. 2); C, reconstitution of carapace (after Wehner 1988: fig. 31a, "typical form from Kimmeridgian", and Müller et al. 2000: fig. 16); D, Ekalakia lamberti Bishop, 1976, United States, Montana, Campanian or Maastrichtian (after Bishop 1976: fig. 1 and Müller et al. 2000: fig. 11): reconstitution of carapace. Scale bars: C, $2 \mathrm{~mm}$; D, $4 \mathrm{~mm}$. 

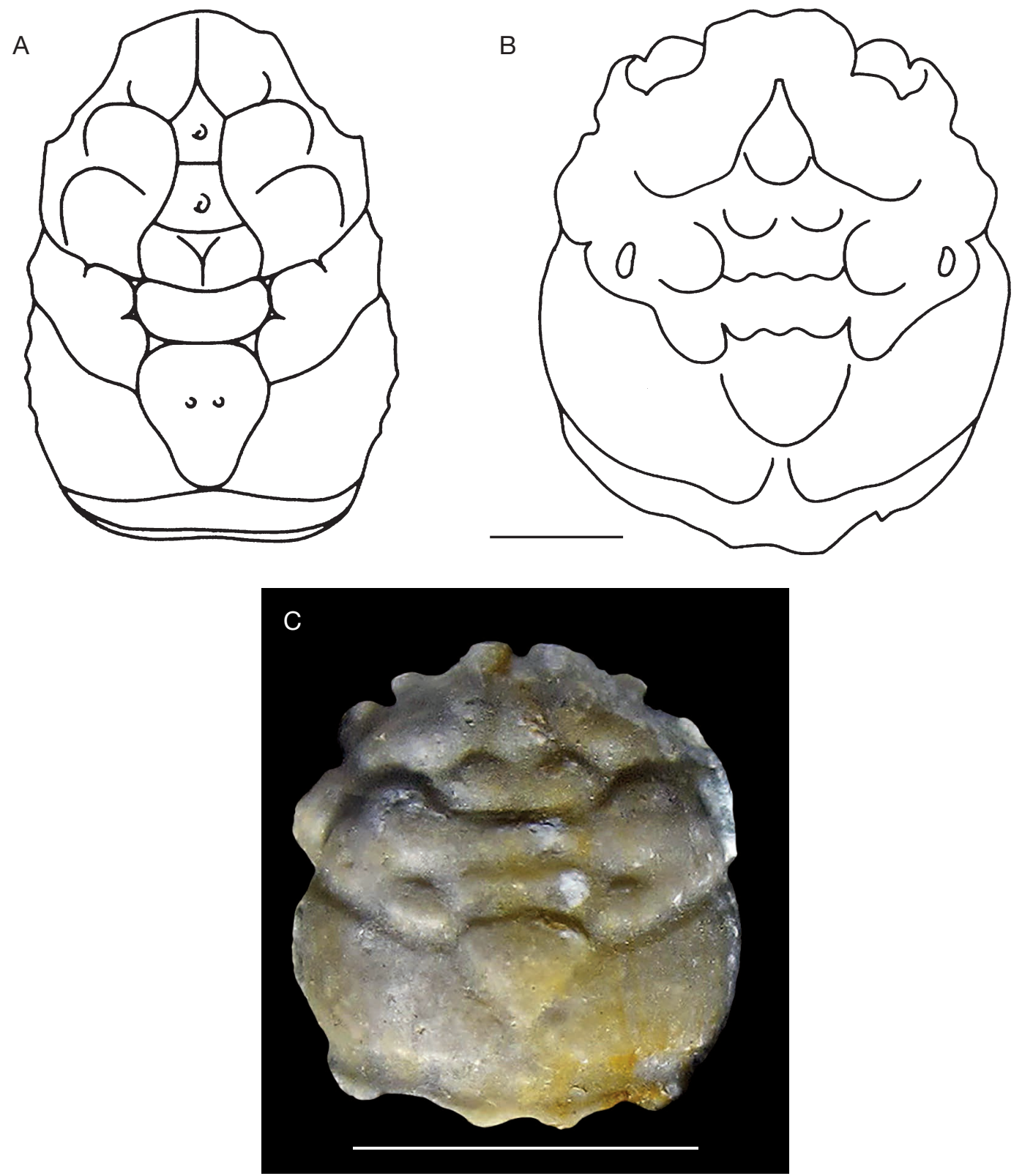

FIG. 8. - A, Vectis wrighti Withers, 1946: reconstitution of carapace (after Glaessner 1969: fig. 296.1a); B, Rathbunopon polyakron Stenzel, 1945: reconstitution of carapace (after Müller et al. 2000: fig. 9); C, Rathbunopon obesum Van Straelen, 1944, Spain, Navarra Koskobilo quarry, Olazti, Late Albian (C-482-1, Àlex Ossó private collection). Photograph courtesy of Àlex Ossó (Tarragona). Scale bars: B, 3 mm; C, 5 mm.

Family HOMOLODROMIIDAE Alcock, 1900

(Fig. 9)

TYPE GENUS. - Homolodromia A. Milne-Edwards, 1880 (type species by monotypy: Homolodromia paradoxa A. Milne-Edwards, 1880).

INCLUDED GENERA (pro parte; see Guinot 1995: figs 1-38; Schweitzer et al. 2004: fig. 6.1; 2012a: 9, figs 6, 7). - Antarctidromia Förster, Gaździcki \& Wrona, 1985 (type species by original designation: A. inflata Förster, Gaździcki \& Wrona, 1985, from the Lower Miocene); Dicranodromia A. Milne-Edwards, 1880 (type species by monotypy: D. ovata A. Milne-Edwards, 1880); ? Eocarcinus Withers, 1932 (type species by monotypy: E. praecursor Withers, 1932); ? Eoprosopon Förster, 1986 (type species by original designation: E. klugi Förster, 1986, from the Lower Jurassic, Liassic [upper lower
Pliensbachian]); Homolus Eudes-Deslongschamps, 1835 (type species by monotypy: $H$. auduini Eudes-Deslongschamps, 1835 , from the Middle Jurassic [Bathonian], senior synonym of Protocarcinus [synonym of Palaeinachus] longipes Woodward \& Salter, 1865; see Guinot 1995: 164; Krobicki \& Zatoń 2016).

\section{REMARKS}

The superfamily Homolodromioidea constitutes the oldest brachyuran lineage that ranges from the late Early Jurassic to the Recent. Extant homolodromiids, known merely by two genera, Homolodromia and Dicranodromia, are characterised by only a weak proepistome or none at all, absence of a true "orbital area" and developed flanks without demarcation (Guinot 1995: fig. 2A, C). 


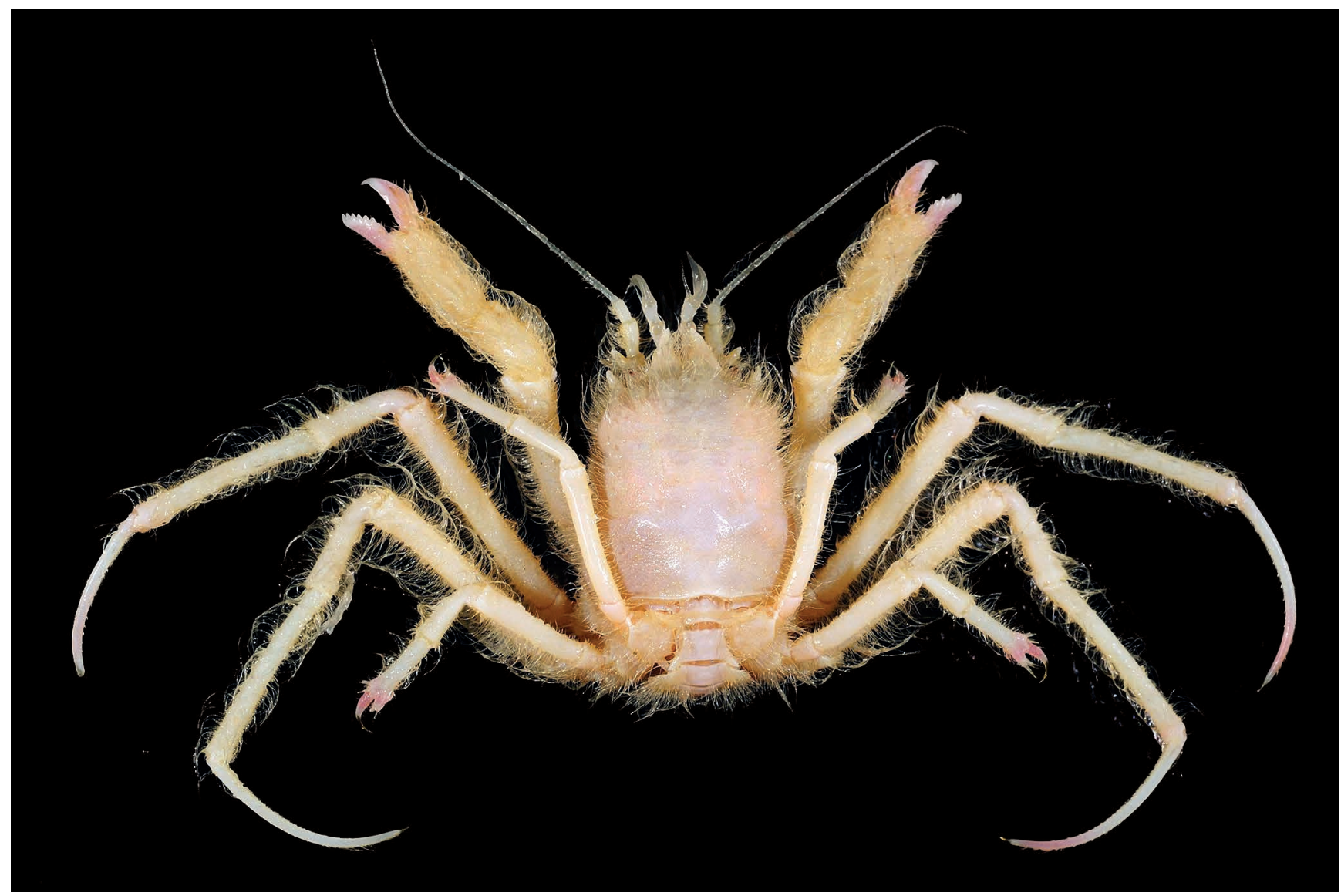

FIG. 9. - Homolodromiidae Alcock, 1900, Homolodromia aff. kai Guinot, 1995, Papua New Guinea, off Woodlark Islands, BIOPAPUA Expedition, stn CP3744, $776-856$ m, 2010, c. $25.0 \times 18.0$ mm (MNHN-IU-2011-932). Photograph courtesy of Laure Corbari (MNHN).

Although generally not quoted in the literature (e.g., Schweitzer \& Feldmann 2009c, as Protocarcinus auduini Eudes-Deslongschamps, 1835), Bouvier (1896: 47-52, fig. 36) and Guinot (1995: 164, 265) were the first authors to demonstrate that Homolus auduini from the Bathonian of France and England belonged to the Homolodromiidae, in which family it probably deserves a separate status. Krobicki \& Zatoń (2016: 705) considered it to be the oldest homolodromiid.

Subsequent to Förster (1985, 1986), Guinot (1995: 265, 268) and Guinot \& Tavares (2001: fig. 21), similarly uncited in recent literature (e.g., Haug \& Haug 2014), discussed the status of both Eoprosopon klugi and Eocarcinus praecursor at length. Eoprosopon klugi, from the upper lower Pliensbachian, might be the earliest known brachyuran (Withers 1932; Förster 1986: 25, figs 1, 2; Guinot 1991: 578, 596; 1995: 111; Müller et al. 2000; Schweitzer \& Feldmann 2010a: 51, fig. 1, as Homolodromioidea incertae sedis; Schweitzer et al. 2012a: fig. 1), but it was referred to as the "oldest unequivocal and most 'primitive' crab" by Haug \& Haug (2014: 149, 155, figs 1-5), in spite of the strong, prominent antenna deemed "unknown among modern crabs", a character shared only with Eocarcinus. In view of the fact that the posterior part of the pleon is poorly preserved, the condition of the uropods still remains questionable, which explains the conflicting interpre- tations of its status (see Guinot \& Tavares 2001: 538; Guinot et al. 2013: 210). A feature that differentiates Eoprosopon klugi from Homolodromia paradoxa and allied forms (Fig. 9) is the cervical groove, which is complete or discontinuous, respectively. This perhaps explains why Krobicki \& Zaton (2008: 30, fig. 1) considered Eoprosopon to be a prosopid. Eocarcinus klugi (Förster 1985: figs 1, 2; Müller et al. 2000: fig. 3) is characterised by reduced P4 and P5, but with P4 proportionaly longer than in typical homolodromiids that have equal or subequal last pereiopods.

For accommodation of Eocarcinus, discarded from the Brachyura and moved to the Anomura by Feldmann \& Schweitzer (2010; see also Krobicki \& Zaton 2008), the family Eocarcinidae Withers, 1932 could be available, as already used by Balss (1957: 1601). Should both Eocarcinus and Eoprosopon be assigned to the Brachyura in similarly high-ranked groups, the name Eocarcinoidea Withers, 1932 is an available nomen (Guinot \& Tavares 2001: 538, fig. 21).

The late Pliensbachian Eoprosopon klugi could be the oldest known brachyuran, predating Homolus auduini, and, after an extensive gap in the fossil record, the next ones could be the early Bajocian Abyssophthalmus hebes (von Meyer, 1840) (Schweigert 2006) and the late early Bajocian Gabriella lugobaensis (Förster, 1985) (see Krobicki \& Zatoń 2016). 


\section{Family KONIDROMITIDAE \\ Schweitzer \& Feldmann, 2010}

Type GENUS. - Konidromites Schweitzer \& Feldmann, 2010 (type species by original designation: Oxythyreus gibbus Reuss, 1858, see Hyžný \& Zorn 2016).

INCLUDED GENERA. - Concavolateris Franțescu, 2011 (type species by original designation: C. barbulescuae Franțescu, 2011).

\section{REMARKS}

This Late Jurassic (Oxfordian) to Late Cretaceous (Campanian) family, elevated to suprafamily rank, Konidromitoidea Schweitzer \& Feldmann, 2010 (Schweitzer \& Feldmann 2010b: fig. 1; Schweitzer et al. 2012a: fig. 12) for two genera (Franțescu 2011: fig. 11), is characterised by the following features: ovoid, strongly vaulted carapace; triangular rostrum; dorsal surface with poorly defined or non-developed regions; deep, continuous cervical groove and weak branchiocardiac groove; deeply concave posterior margin; steep, unusually concave flanks, supposedly for accommodation of the meri of the pereiopods (Schweitzer $e t a l$. 2012a: 20), resulting in a compact body. The Konidromitidae is a podotreme family that appears to belong to the Dynomeniformia, within the Dromioidea and Dromiidae. There is a certain resemblance to extant dromiine genera such as Pseudodromia Stimpson, 1859 and Ascidiophilus Richters, 1880 (Fig. 4B, C), whose species, with concave flanks for accommodation of the pereiopods, are especially adapted for living in association with ascidians (Guinot \& Wicksten 2015: fig. 71-11.3G).

Family LECYTHOCARIDAE Schweitzer \& Feldmann, 2009 (Fig. 10A-D)

Type Genus. - Lecythocaris von Meyer, 1860 (type species by monotypy: Prosopon paradoxum von Meyer, 1858).

InCluded GENERA. — Prolecythocaris Schweigert \& Robins, 2016 (type species by original designation: P. hauckei Schweigert \& Robins, 2016).

\section{REMARKS}

Lecythocarids are tiny crabs. The neotype of Lecythocaris paradoxa (Fig. 10A, C) measures 5.5 ×5.2 mm (Wehner 1988: 65, fig. 18, pl. 4, fig. 9; see Müller et al. 2000: fig. 17J); the holotype of L. stoicai Franțescu, 2011 measures $6.6 \times 6.9 \mathrm{~mm}$ (Franțescu 2011: 290, fig. 14). The holotype (Fig. 10D) and paratype of Prolecythocaris hauckei Schweigert \& Robins, 2016 measure $3.6 \times 4.0 \mathrm{~mm}$ and $5.9 \times 6.4 \mathrm{~mm}$, respectively (Schweigert \& Robins 2016), while $P$. rieberi Schweigert, 2019 attains a length and width of $3.6 \times 4.0 \mathrm{~mm}$, respectively (Schweigert 2019).

The Late Jurassic Lecythocaris, assigned to the Prosopidae (von Meyer, 1860; Patrulius 1966; see Krobicki \& Zatoń 2008: fig. 1), was always thought to belong to the Dromiacea, within the Homolodromioidea (Van Straelen 1925: 163; Wehner 1988: 63, fig. 18, pl. 4, figs 8, 9; Müller et al. 2000: figs 1, 7, 17J), until it was given family status, the Lecythocaridae, within the Glaessneropsoidea (Schweitzer \& Feldmann 2009a: 82, 94, figs 1.7, 6; Karasawa et al. 2011: tables 1, 2; Franțescu 2011: 290, fig. 14; Schweitzer et al. 2012a: fig. 15.1a-c; 2018a: fig. 17.11).
The genus Lecythocaris includes two species: L. paradoxa (von Meyer, 1858) (von Meyer 1858; 1860: 215, pl. 23, fig. 31, as Prosopon paradoxum; Quenstedt 1867: pl. 26, fig. 11, as Prosopon; Moericke 1897: 58, pl. 6, fig. 12, as Prosopon; Van Straelen 1925: 357, fig. 163; Patrulius 1966: 509, pl. 30, fig. 9, as L. paradoxa strambergensis; Glaessner 1969: R484, fig. 294.4; Wehner 1988: 64, fig. 18, pl. 4, figs 8, 9; Müller et al. 2000: 52, figs 1, 7, 17J; Schweitzer \& Feldmann 2009a: 94, fig. 6.1-6.5, table 1; Schweigert \& Robins 2016: fig. 2C, D; Schweigert 2019; Schweitzer et al. 2018a: fig. 17.11) (Fig. 10A-C), and L. obesa Schweitzer \& Feldmann, 2009 (Schweitzer \& Feldmann 2009a: 99, figs 1.7, 6.6-6.8) with extremely well-developed hepatic, epibranchial, metabranchial swellings and with a conspicuous flange.

Prolecythocaris hauckei Schweigert \& Robins, 2016, from the lower Kimmeridgian of Franconia, Germany (Schweigert \& Robins 2016: 32: fig. 2A, B), is a very small crab with a striking posterior rim (Fig. 10D), while P. rieberi Schweigert, 2019, from the Upper Jurassic (upper Kimmeridgian), also has a posterior rim that is smooth in contrast with the pustulose dorsal surface and the inflated, coarsely tuberculated subhepatic region (Schweigert 2019: fig. 2A-D).

Lecythocarids (Fig. 10) share certain features with the Cenomanian genus Archaeochiapasa (Fig. 1A, B, D) (Guinot et al. 2019), namely a flange along the strongly rimmed posterior margin of the carapace, very protruding subhepatic regions, pustulose swellings and deep grooves on the dorsal surface of the carapace. The flange found in the Lecythocaridae was described as a "very wide posterior margin" (Van Straelen 1925: 357), as "a broad, smooth marginal furrow" (Schweitzer \& Feldmann 2009a: 97) or as a "rim". Both Lecythocaris and Prolecythocaris show a short carapace (excluding the rostrum), a sulcate rostrum, a well developed cervical groove separated from branchiocardiac groove by a small space, an extremely swollen hepatic area that marks the widest point of the carapace, and a large cardiac region that extends down to the posterior margin.

Patrulius (1959) assumed that Lecythocaris could be a precursor of the majoid lineage, but Schweitzer \& Feldmann (2009a) rejected this hypothesis, arguing that both the rostrum and the construction of the orbits were different. However, it must be borne in mind that the classification of the Majoidea, with almost 1000 species assigned to 200 genera, cannot be based solely upon orbital configuration. In fact, the orbits vary from more or less incomplete to complete according to majoid families/ subfamilies. According to Schweitzer \& Feldmann (2009a: 95) the analogous carapace shape of majoids and lecythocarids, both with strong pustular ornamentation, inflated areas, deep furrows and prominent spines that could have served as camouflage, was perhaps an adaptation to a semi-cryptic, benthic lifestyle "in which concealment in vegetation or niches was facilitated by a compact body form and irregular outline".

Actually, lecythocarids do not appear to be podotreme crabs (Guinot et al. 2019: fig. 13A-C) but, in spite of their Jurassic age, are here considered possible eubrachyurans, by analogy with archaeochiapasid carapace (Fig. 1A, B, D), whose thoracic sternum and pleon (Fig. 1C) indicate a non-podotreme nature (Guinot et al. 2019: fig. 11). A comparison of carapaces of Lecythocaris stoicai (Franțescu 2011: fig. 14) and, for exam- 

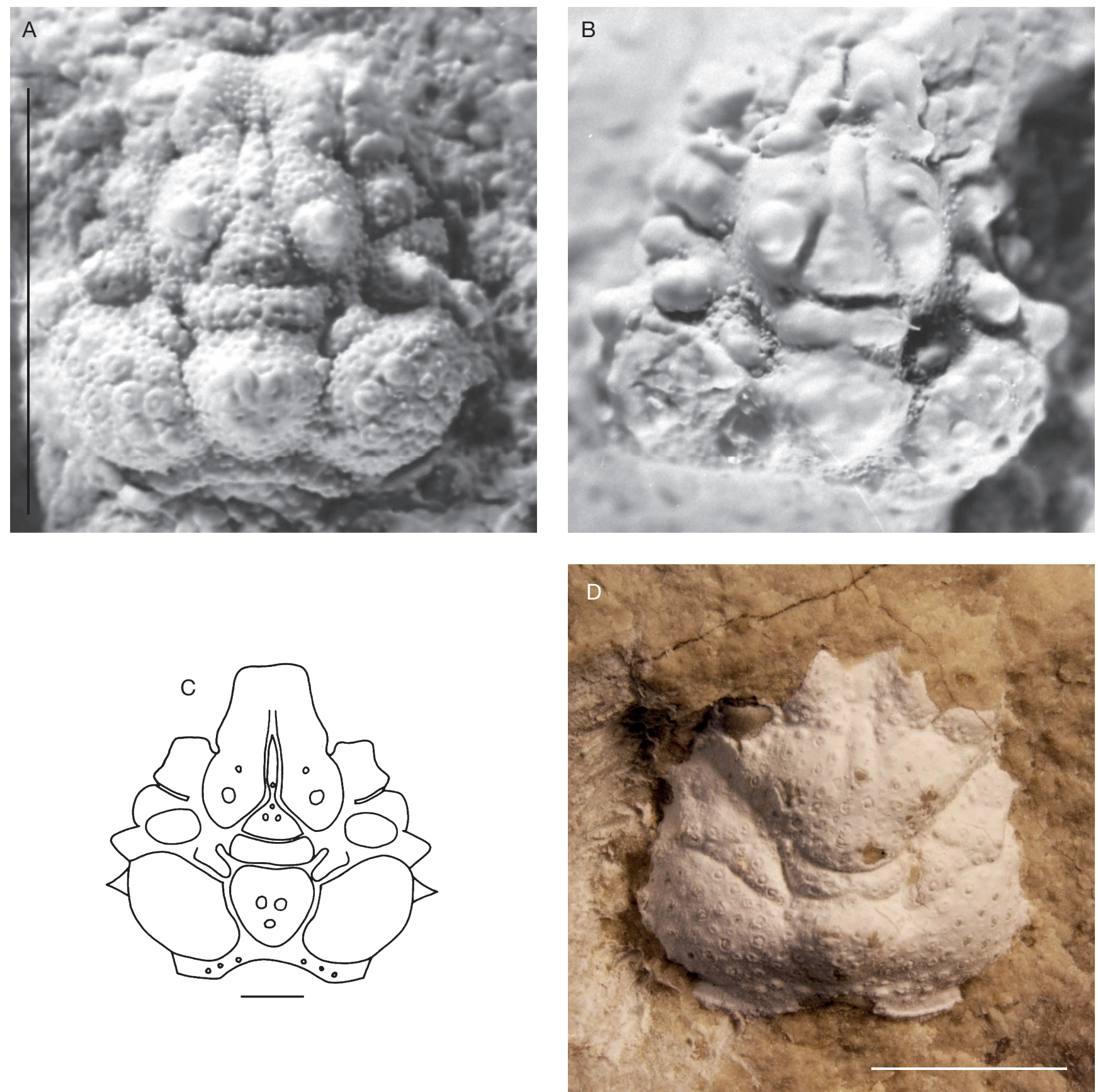

FIG. 10. - Lecythocaridae Schweitzer \& Feldmann, 2009: A-C, Lecythocaris paradoxa (von Meyer, 1858); A, neotype, $5.5 \times 5.2$ mm, original specimen of Quenstedt (1867: pl. 26, fig. 11), Germany, Baden-Württemberg, Örlinger Tal bei Ulm, Kimmeridgian (Museum Tübingen); B, Germany, Baden-Würtemberg, Geislingen an der Steige, Kimmeridgian (SMNS-61657) (both after Wehner 1988: pl. 4, figs 8 and 9, respectively); C, reconstruction of neotype (after Wehner 1988: fig. 18; Müller et al. 2000: fig. 7); D, Prolecythocaris hauckei Schweigert \& Robins, 2016: holotype, $3.6 \times 4.0$ mm, in cuticle preservation, southern Germany, Bavaria, Titting, lower Kimmeridgian (SMNS 70326/1). Photograph courtesy of G. Schweigert (Stuttgart). Scale bars: A, 5 mm; C, D, 2 mm.

ple, of the Middle Eocene Planobranchia palmuelleri Artal, Van Bakel \& Onetti, 2014, with inflated branchial regions, diagnosed by a "posterior margin convex, very broad, notably rimmed" and assigned to the Inachidae MacLeay, 1838 (Artal et al. 2014: 156, pl. 1), shows additional studies in numerous groups are called for. Planobranchia laevis (Lörenthey, 1909) and P. simplex (Remy in Gorodiski \& Remy, 1959), from the Eocene, were referred to the Majinae Samouelle, 1819, rather than to the Micromaiinae Beurlen, 1930 as was advocated by Schweitzer \& Feldmann (2010f: 407, fig. 2A, B). A part of my study here is to determine the potential eubrachyuran superfamily that could accommodate it. There is conclusive evidence to advocate for a majoid affiliation, namely to the extant basal family Oregoniidae (Fig. 18).

In my opinion, the Lecythocaridae might constitute an extinct majoid family (see Discussion below). 

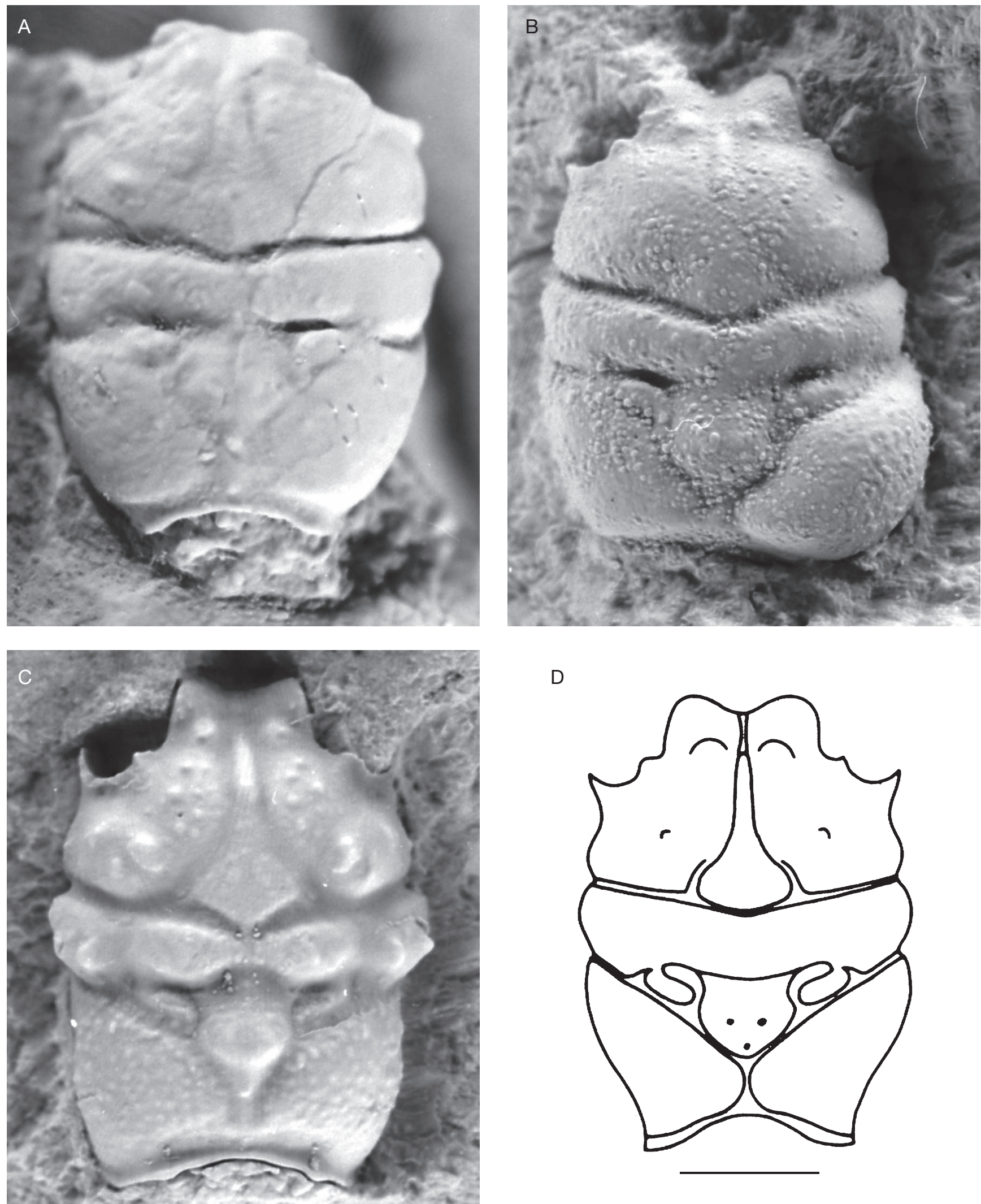

$\mathrm{D}$

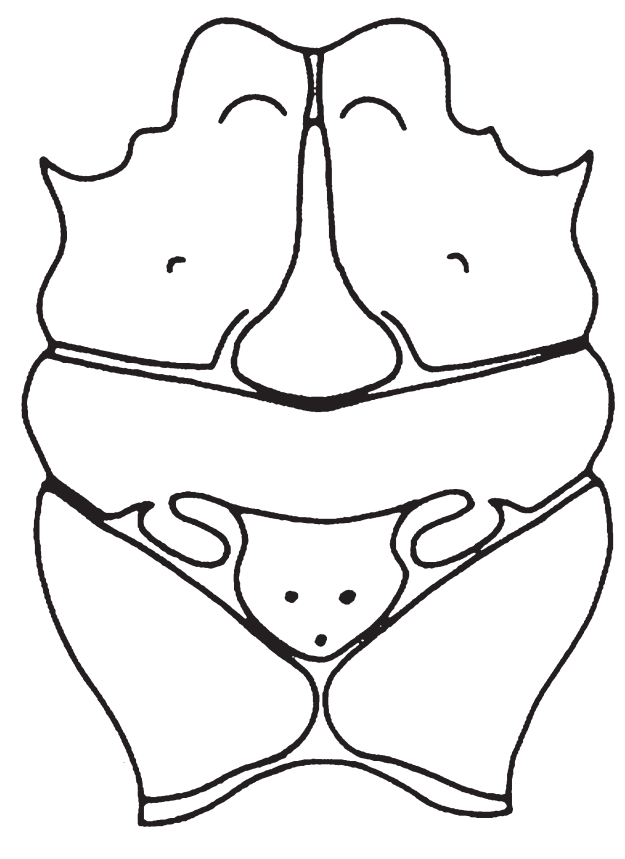

FIG. 11. - Taxa assigned to Longodromitidae Schweitzer \& Feldmann, 2008 by Schweitzer et al. (2012a): A, B, D, Longodromites excisus (von Meyer, 1857): A, neotype, original specimen of Quenstedt (1858: pl. 95, fig. 38), Germany, Örlinger Tal bei Ulm, Kimmeridgian (Museum Tübingen); B, Germany, Spielberg/ Hahnenkamm, Oxfordian (BSP-1998 I 90) (both after Wehner 1988: pl. 7, figs 5, 7 respectively); C, Abyssophthalmus spinosus (von Meyer, 1842), neotype 11.1 × 8.0 mm, Germany, Biburg bei Weissenburg, Oxfordian (BSP 1980 XXX 528) (after Wehner 1988: pl. 2, fig. 9, as Nodoprosopon spinosum); D, reconstitution of carapace based on several specimens (after Wehner 1988: fig. 29a). Scale bar: D, $3 \mathrm{~mm}$. 

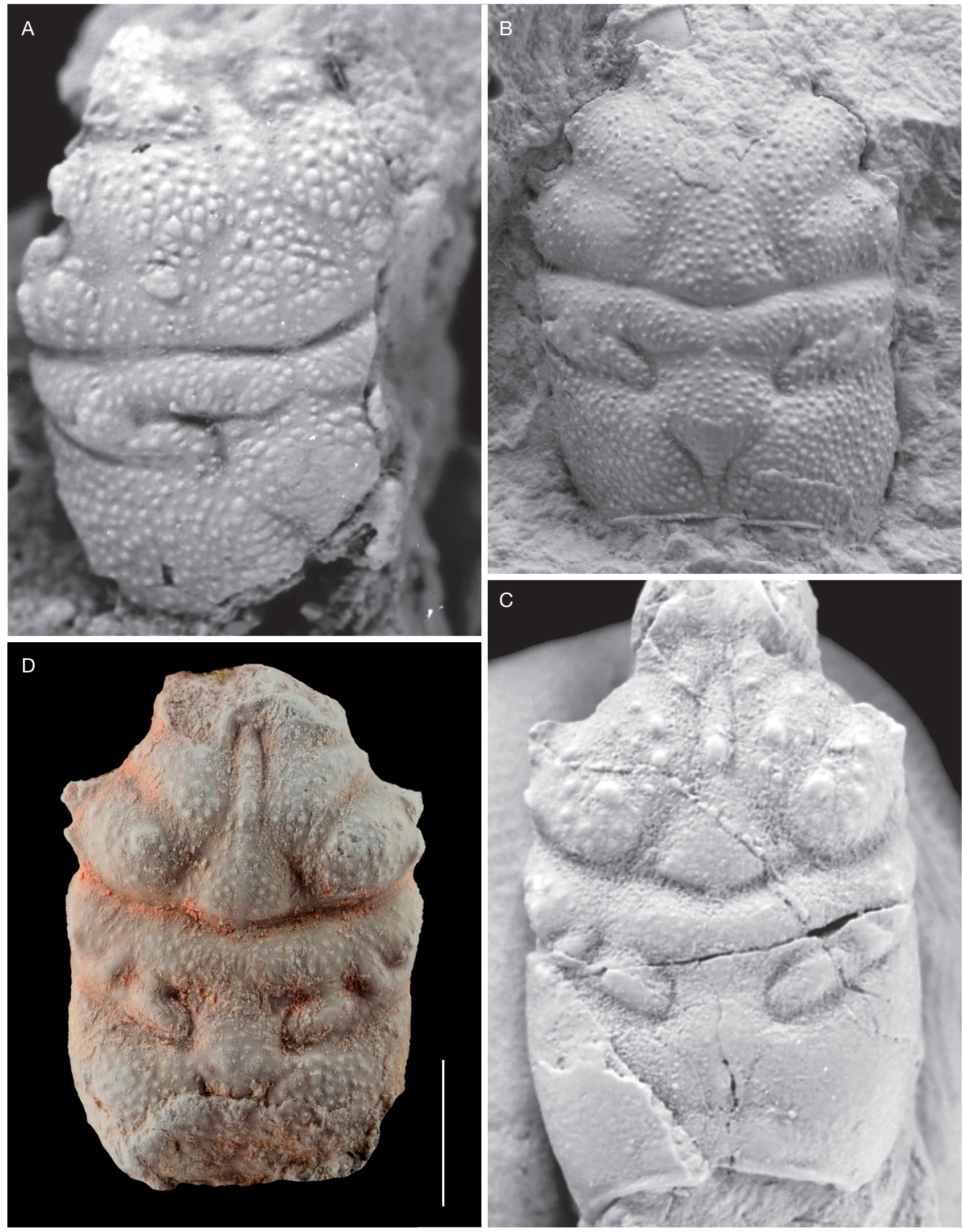

FIG. 12. - Taxa assigned to Longodromitidae Schweitzer \& Feldmann, 2008 by Schweitzer et al. (2012a): A, B, Abyssophthalmus mirus (Moericke, 1897); A, holotype $9.3 \times 6.6 \mathrm{~mm}$, original specimen of Moericke (1897) (BSP AS III 315), Czech Republic, Moravian-Silesian Region, Chotěbuz (Kotzobenz), Štramberk Limestone, Tithonian; B, Germany, Lauterburg, Kimmeridgian (SMNS 61630) (both after Wehner 1988: pl. 4, figs 4 and 5, respectively, as Nodoprosopon mirum); C, D, Planoprosopon heydeni (von Meyer, 1857); C, neotype, original specimen of Quenstedt (1858: pl. 95, fig. 36), Germany, Baden-Würtemberg, Örlinger Tal bei Ulm, Kimmeridgian (Museum Tübingen) (after Wehner 1988: pl. 2, fig. 5); D, NE Spain, Zaragoza, Moneva, Oxfordian (MPZ 94/1511). Photograph courtesy of Ari Ferratges. Scale bar: D, $2 \mathrm{~mm}$. 

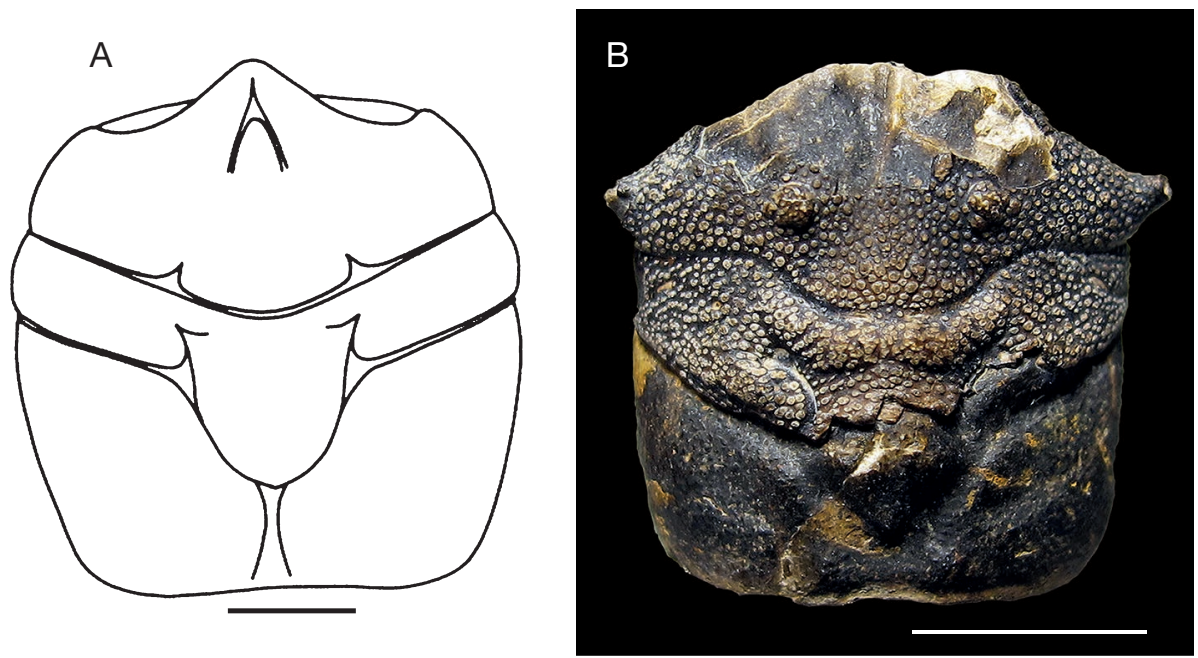

FIG. 13. - A, Coelopus hoheneggeri (Moericke, 1889): reconstitution of carapace of holotype $8.6 \times 8.2$ mm, original specimen of Moericke (1889: pl. 6, fig. 18) (BSP AS III 310), Moravia, Koniakau, upper Tithonian (after Wehner 1988: fig. 28a; Müller et al. 2000: fig. 13a); B, Glaessnerella spinosa (Van Straelen, 1936), Lower Cretaceous, Albian, Courcelles (Poitou-Charentes, France) (C-408-1, Àlex Ossó private collection). Photograph courtesy of Àlex Ossó (Tarragona). Scale bars: A, $2 \mathrm{~mm}$; B, $5 \mathrm{~mm}$.

Family LONGODROMITIDAE Schweitzer \& Feldmann, 2009 (Figs $11 ; 12 ; 13 \mathrm{~B})$

TYPE GENUS. - Longodromites Patrulius, 1959 (type species by original designation: Pithonoton angustum Reuss, 1858, from the Upper Jurassic [Oxfordian-Tithonian]).

INCLUDED GENERA (according to Schweitzer \& Feldmann 2009a: 57, 62, 100, table 2; Schweitzer et al. 2012a: fig. 8; 2018: 320 pro parte; Klompmaker 2013). — Abyssophthalmus Schweitzer \& Feldmann, 2009 (type species by original designation: Prosopon spinosum von Meyer, 1842); Antarctiprosopon Schweitzer \& Feldmann, 2011 (type species by original designation: Homolodromia chaneyi Feldmann \& Wilson, 1988); Dioratiopus Woods, 1953 (type species by original designation: D. salebrosus Woods, 1953); Glaessnerella Wright \& Collins, 1975 (synonym of Glaessneria Wright \& Collins, 1972) (type species by original designation: Homolopsis spinosa Van Straelen, 1936); Navarrara Klompmaker, 2013 (type species by original designation: Navarrara betsieae Klompmaker, 2013); Pilidromia Schweitzer, Feldmann, Lazăr, Schweigert \& Franțescu, 2018 (type species by original designation: Planoprosopon thiedeae Schweigert \& Koppka, 2011); Planoprosopon Schweitzer, Feldmann \& Lazăr, 2007 (type species by original designation: Prosopon heydeni von Meyer, 1857); Vespridromites Schweitzer \& Feldmann, 2011 (type species by original designation: Dioratiopus hearttailensis Bishop, 1985).

\section{REMARKS}

Here I list most of the genera assigned to the Longodromitidae by Schweitzer et al. (2012a). The family, which seems paraphyletic, was first referred to the Glaessneropsoidea by Schweitzer \& Feldmann (2009a) and Karasawa et al. (2011: table 1), but subsequently reassigned to the Homolodromioidea by Schweitzer et al. (2012a, 2018b) and most other authors (e.g., Jagt et al. 2015; Karasawa \& Hirota 2019; Nyborg et al. 2019).

The type species of Longodromites, L. angustus, formerly regarded as a prosopid (Patrulius 1966: pl. 31, figs 25, 26), was included either in the Glaessneropsoidea (Franțescu 2011: fig. 15) or in the Homolodromioidea (Hyzný et al. 2015: figs 3,
$8 \mathrm{~B})$. The posterior margin of the carapace is bordered over its entire length by a "gutter" ("rigole" in French; see Patrulius 1966: 515) and is "strongly inflected" according to Hyzný et al. (2015: 638). L. excisus (von Meyer, 1857) (Fig. 11A, B, D) (von Meyer 1860: 207, pl. 23, fig. 20; Wehner 1988: 111, figs 29-30a-b, pl. 7, figs 5-7; Schweitzer \& Feldmann, 2009a: fig. 7.1-7.3; Müller et al. 2000: fig. 18G) was differentiated by Schweitzer \& Feldmann (2009a: 108) from other longodromitids by the carapace with weakly convex lateral margins and circular epibranchial extensions, a flattened dorsal surface, and a moderately broad fronto-orbital margin. L. ovalis (Moericke, 1897) has a markedly ovate carapace, a granular dorsal surface and a relatively narrow fronto-orbital margin (Schweitzer \& Feldmann 2009a: 106, fig. 7.8-7.10). As Wehner (1988) regarded these three species as possible synonymous, a new examination would be useful.

Prosopon heydeni von Meyer, 1857, reassigned to Avihomola Van Straelen, 1925 (Van Straelen 1925) and later to Nodoprosopon (Collins \& Wierzbowski 1985: pl. 1, figs 3, 4), was finally designated as the type species of Planoprosopon by Schweitzer et al. (2007), but left in Nodoprosopon by Ferratges (2017: 42, fig. 21): it is a common form in the Upper Jurassic of the Tethyan realm (Fig. 12C, D). Planoprosopon heydeni, P. aequum (von Meyer, 1860), P. kashimaense Kato, Takahashi \& Taira, 2010, recorded from the Upper Jurassic (upper Kimmeridgian to lower Tithonian, see Kato et al. 2010: fig. 6), two recent species of Planoprosopon from the Upper Jurassic-Lower Cretaceous (Karasawa \& Hirota 2019), Abyssophthalmus (see Klompmaker et al. unpublished: fig. 3I) (Figs 11C; 12A, B), Antarctiprosopon Schweitzer \& Feldmann, 2011, and Pilidromia (see Schweitzer et al. 2018a) are all considered homolodromioids. However, a review of all species included in Longodromitidae appears necessary to verify their status. For example, it appears incorrect to include in the same superfamily the genera Antarctiprosopon, 

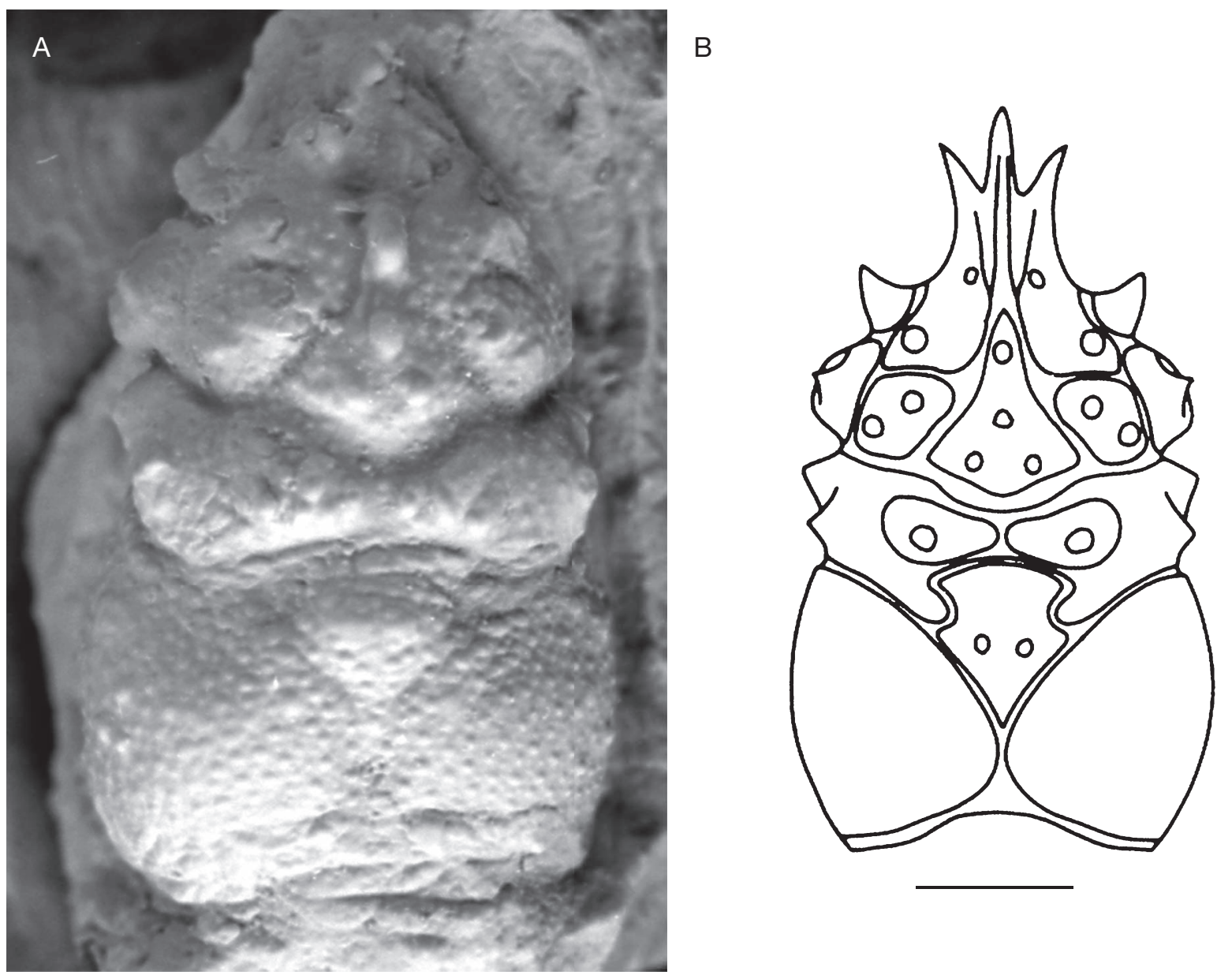

FIG. 14. - Nodoprosopidae Schweitzer \& Feldmann, 2009. Nodoprosopon ornatum (von Meyer, 1860): A, neotype, original specimen of Quenstedt (1858: pl. 95, fig. 37), $12.2 \times 6.5$ mm, Germany, Örlinger Tal, Baden-Würtemberg, Kimmeridgian (Museum Tübingen) (after Wehner 1988: pl. 3, fig. 5); B, reconstitution of carapace based on several specimens (after Wehner 1988: fig. 14a; Müller et al. 2000: fig. 6a). Scale bar: B, 2 mm.

with $A$. chaneyi (Feldmann \& Wilson, 1985), which looks to be a typical homolodromioid, and Coelopus Étallon, 1861 (Fig. 13A) (type species by monotypy: C. jolyi Étallon, 1861) referred to the Glaessneropsoidea in the generic revision by Schweitzer \& Feldmann (2010e: fig. 1).

Several species of Glaessnerella are known from the Early Cretaceous (Aptian, Albian) and late Cretaceous (Cenomanian) of Great Britain and France, but the recently described G. yamoori Nyborg, Garassino, Vega \& Kovalchuk, 2019, from the Albian of Oregon (Nyborg et al. 2019: fig. 4), represents the first report of the genus outside Europe. According to Van Bakel et al. (2012c), some species of Glaessnerella that do not conform to G. spinosa (Van Straelen, 1936) (Van Straelen 1936; Wright \& Collins 1972: fig. 6f-i, pl. 4, figs 1-6) (Fig. 13B) may be turn out to be members of the Homoloidea.

Krobicki \& Zatoń (2016: 708, 709, table 1) tentatively assigned to Abyssophtalmus a number of taxa from the lower Callovian that had been described by Crônier \& Boursicot (2009), i.e., one species of Tanidromites and two species presumed to belong to Nodoprosopon, but left in Tanidromites in their Table 1. Schweitzer et al. (2018b: 321) have recently included in Abyssophtalmus the Nodoprosopon? mainense and
Nodoprosopon? bellaii of Crônier \& Boursicot (2009), as well as Prosopon hebes von Meyer, 1840 (see Schweigert 2006; Schweigert \& Koppka 2011).

In conclusion, although the family Longodromitidae appears to be a catch-all and paraphyletic and, despite the affiliation of some members to the Glaessneropsoidea, all the included genera/species are podotremes.

Family NodoprosopidaE Schweitzer \& Feldmann, 2009 (Fig. 14A, B)

TYPE GENUS. - Nodoprosopon Beurlen, 1928 (type species by original designation: Prosopon ornatum von Meyer, 1860).

\section{REMARKS}

This monotypic family, only known with certainty by the type species Nodoprosopon ornatum from the Upper Jurassic (Kimmeridgian-Tithonian) (see Balss 1957: fig. 1174 as Prosopon ornatum; Patrulius 1966: fig. 5, pl. 30, fig. 8; Wehner 1988: 47, fig. 14, pl. 3, figs 3-5; Müller et al. 2000: figs 6, 17E-I; Schweitzer et al. 2007: 101, fig. 2.1-4, table 1; see also Wright \& Collins 1972: 
31, in their discussion of the Latreilliidae), is currently assigned to the superfamily Glaessneropsoidea (Schweitzer \& Feldmann 2009a: 116; Schweitzer \& Feldmann 2012a: 24, fig. 15.2a-c; Artal et al. 2012). Nodoprosopon ornatum (Fig. 14A, B) shows a globular, lobulated carapace with the maximum width in the mid-branchial region, an ornamented dorsal surface, and a trifid rostrum. The concave posterior margin is rimmed (described [translated from German] as with "a rather wide rimmed indentation" by von Meyer 1860: 212), the subhepatic regions are inflated, and the dilated branchial regions do not show an interbranchial space. I agree with Schweitzer \& Feldmann (2009a: 101) that the morphology of several species assigned to Nodoprosopon "falls outside the range of morphology that can be accommodated within a single brachyuran genus, or even family".

Artal et al. (2012: 403) noted that in the familial diagnosis by Schweitzer \& Feldmann (2009a: 116, 117, fig. 10) the lateral margins of the carapace were described as spinose, while the illustrations showed salient nodes, similar to the lateral complex typical of their new genus Viaia Artal, Van Bakel, Fraaije, Jagt \& Klompmaker, 2012, even if preservation did not allow to state this beyond doubt. Klompmaker (2013: 169), who recognised some similarities in the carapaces between his new priscinachids (Majoidea) and the Nodoprosopidae ("the Nodoprosopidae have been considered as well for placement of Priscinachus, Cretamaja, and Koskobilius because of the general resemblance in overall shape") but, based on Schweitzer \& Feldmann (2009a), rejected the hypothesis of a relationship of the nodoprosopids with the Majoidea, an eventuality that should nevertheless be thoroughly considered (see Fig. 14B).

The distinctive trifid rostrum and triangular carapace shape of Nodoprosopon ornatum are not seen in questionable species such as the early Callovian N.? mainense Crônier \& Boursicot, 2009 and N.? bellaii Crônier \& Boursicot, 2009 (their fig. 3E-G, pl. 1, figs 9-16, pl. 2, fig. 4 and fig. 3H-J, pl. 2, figs 1-3, respectively), both included in Abyssophtalmus by Krobicki \& Zatoń (2016), as noted above.

The family Nodoprosopidae, exemplified by $N$. ornatum, is close to the Bucculentidae Schweitzer \& Feldmann, 2009 (Schweitzer \& Feldmann 2009a: 78, fig. 3.3, 3.4; Schweitzer et al. 2012a: 2-3, fig. 2) (see Fig. 2A-D). The both families are provided with similar diagnoses in the Treatise Online (Schweitzer et al. 2012a: see p. 2-3 for the Bucculentidae; p. 24 for the Nodoprosopidae), as follows: carapace longer than wide, regions ornamented with large tubercles; cervical and branchiocardiac grooves deep; protogastric regions differentiated; hepatic regions strongly inflated; posterior margin broadly concave, rimmed; rostrum trifid. The only differences (see the key in Schweitzer \& Feldmann 2009a: 61-62) are visible in the orbits: these are not developed in the Nodoprosopidae (vs orbits located under rostrum and orbital area on hepatic region in the Bucculentidae) and, perhaps, the widest point of carapace at the position of the mid-branchial region in the Nodoprosopidae (vs at the position of the hepatic regions in the Bucculentidae). Some species of Nodoprosopon could be synonymous with bucculentid taxa.

The Nodoprosopidae and Bucculentidae could both rank amongst presumed eubrachyurans as here recognised (see Discussion below).

\section{Family ProsopidaE von Meyer, 1860}

(Fig. 15)

Type Genus. - Prosopon von Meyer, 1835 (type species by subsequent designation by Van Straelen [1925: 371], anteriorly to Beurlen [1928]: Prosopon tuberosum von Meyer, 1840, from the Middle Jurassic [Bathonian]).

INCLUDED GENERA. - Acareprosopon Klompmaker, 2013 (type species by original designation: Pithonoton bouvieri Van Straelen, 1944, from the upper Albian); Laeviprosopon Glaessner, 1933 (type species by original designation: Prosopon laeve von Meyer, 1857); Nipponopon Karasawa, Kato \& Terabe, 2006 (type species by original designation: $N$. hasegawai Karasawa, Kato \& Terabe, 2006, from the Lower Cretaceous [Barremian]). For all of these, reference is made to Schweitzer \& Feldmann 2009a: fig. 2.9, table 2; Karasawa et al. 2011: 536; Schweitzer et al. 2012a: fig. 10; 2018; Artal et al. 2012; Starzyk 2013, 2016; Schweigert \& Koppka 2011: fig. 5; Krobicki \& Zatoń 2016; and Schweitzer et al. 2018a.

\section{REMARKS}

The Prosopidae was assigned to the Homolodromioidea (Schweitzer \& Feldmann 2009a: fig. 2; Schweitzer et al. 2012a). The type species of the type genus Prosopon, P. tuberosum, is known exclusively from the original description and illustration, the type specimen being probably lost (Schweitzer \& Feldmann 2009a: 67), which means that a neotype should be designated. Although restricted, the family is probably not monophyletic in its present composition, and a revision of the included genera and species would certainly be welcome.

Prosopon barbulescuae Schweitzer, Feldmann, Lazăr, Schweigert \& Franțescu, 2018 (Schweitzer et al. 2018a: fig. 13.1-3) differs from all congeners in being widest at the position of the epibranchial region, instead of at the level of the meso/metabranchial regions; it should also be noted that the posterior margin of the carapace is widely rimmed.

Species of Laeviprosopon, a genus revised by Schweitzer \& Feldmann (2008b: 277: fig. 1; Schweitzer et al. 2012a: fig. 10.2a-b) and that contains many species formerly assigned to Prosopon (Schweitzer \& Feldmann 2008b: 277: fig. 1), are diagnosed by a striking carapace sculpture (deep, concave cervical groove; deep but short, axially interrupted postcervical groove; shallow branchiocardiac groove), as in Laeviprosopon punctatum (von Meyer 1860) figured here (Fig. 15A). Some previous authors (Patrulius 1966; Collins \& Wierzbowski 1985) have placed Laeviprosopon within the Homoloidea. According to Schweitzer \& Feldmann (2008b), who compared the breakage pattern of $L$. laeve and that of an extant homolid taxa (thus with lineae homolicae), the actual trace of the breakage in L. laeve (vertical lateral sides of the carapace not proximal vs distal to the break) showed a homolodromioid condition, i.e. a poorly calcified wide area of exuviation shed at the moulting clearly delimited from the rest of the calcified carapace.

When describing Laeviprosopon lazarae Franțescu, 2011 and listing the species included in the genus, Franțescu (2011: 287, 288, fig. 12) drew attention to important differences in comparison with the type species of Laeviprosopon, L. leave. 

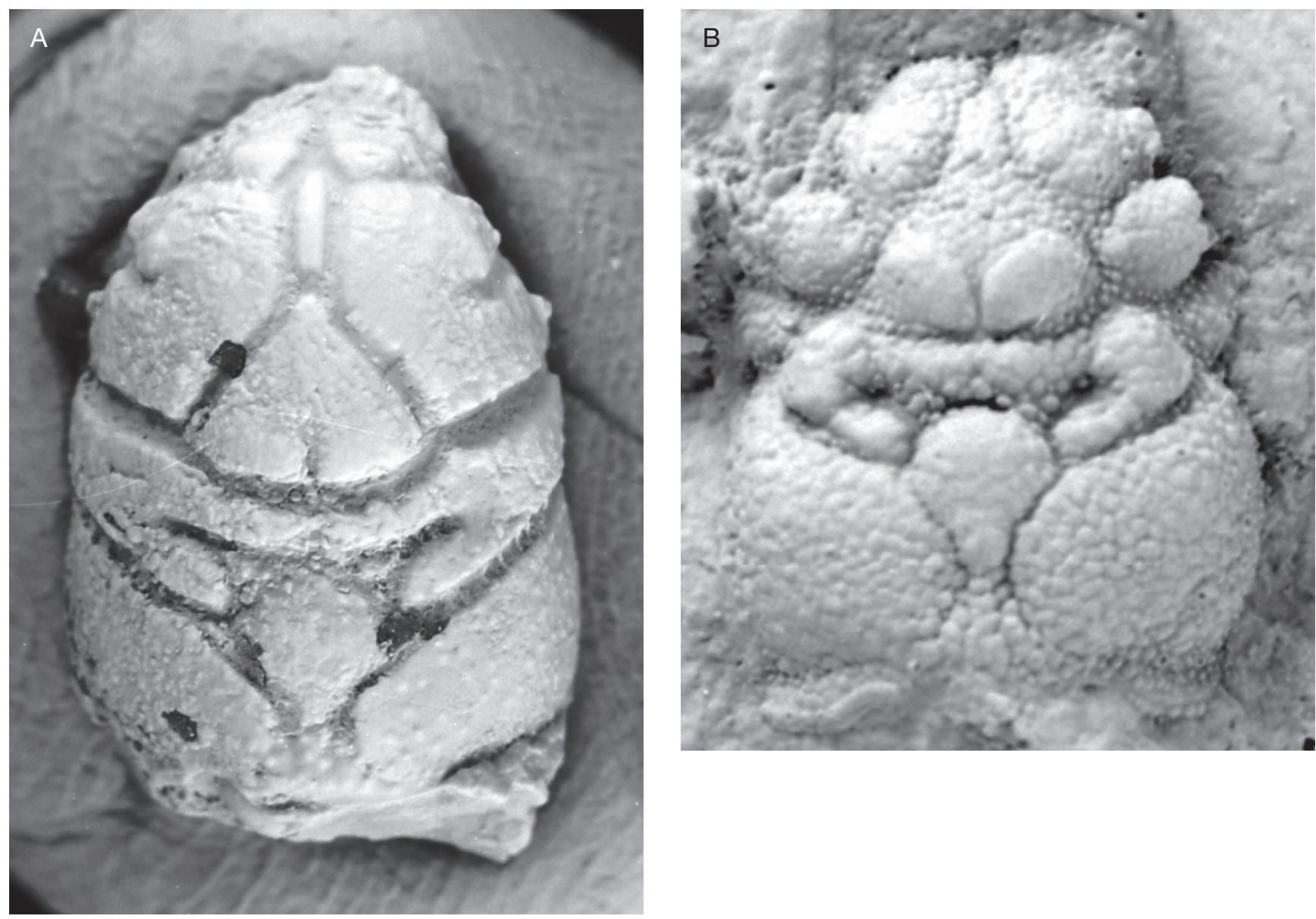

FIG. 15. - Prosopidae von Meyer, 1860: A, Laeviprosopon punctatum (von Meyer, 1860), neotype, original specimen of Moericke (1889), Moravia, Chotěbuz (Kotzobenz), Upper Tithonian (BSP AS III 307) (after Wehner 1988: pl. 1, fig. 5, as Prosopon punctatum); B, Protuberosa protuberosa (Wehner, 1988), holotype, Germany, Saal bei Kelheim, Kimmeridgian (SYL-Nr 1) (after Wehner 1988: pl. 1, fig. 3, as Prosopon protuberosum).

A number of forms assigned to the Prosopidae, such as Prosopon verrucosum Reuss, 1858 (see Schweitzer \& Feldmann 2009a: figs. 2.7, 2.8, 2.11, 2.12), appear to show the same characteristics that are seen in the glaessneropsoids (Fig. 7). In contrast, Protuberosa Schweitzer \& Feldmann, 2009 (type species by original designation: Prosopon protuberosum Wehner, 1988 (Wehner 1988: pl. 1, figs 3, 4) (Schweitzer \& Feldmann 2009a: 76, fig. 2.9; Schweitzer et al. 2012a: fig. 10.4) (Fig. 15B) looks like a bucculentid (see Fig. 2), and its taxonomic position needs to be reconsidered (see Discussion below).

The family Prosopidae is certainly in need of a more detailed study (see below under Tanidromitidae).

Family TANIDROMITIDAE

Schweitzer \& Feldmann, 2008

(Fig. 16)

Type Genus. - Tanidromites Schweitzer \& Feldmann, 2008 (type species by original designation: Prosopon insigne von Meyer, 1860, from the middle Oxfordian).

InCLUDED GENERA. - Gabriella Collins, Ross, Genzano \& Mianzan, 2006, replacement name for Foersteria Wehner, 1988 (type species by original designation: Foersteria biburgensis Wehner, 1988, from the upper Oxfordian).

\section{REMARKS}

The Tanidromitidae, widely accepted as ranking amongst the oldest brachyuran families, is currently assigned to the Homolodromioidea, based on the elongate and highly vaulted carapace with near-parallel lateral margins and strongly developed flanks; an axially sulcate, downturned rostrum; circular orbital fossae; and concave (occasionally, albeit rarely, elevated) orbital area (Schweitzer \& Feldmann 2008a, 2009c, 2011; Crônier \& Boursicot 2009; Franțescu 2011; Hyžný et al. 2011; Schweigert \& Koppka 2011; Schweitzer et al. 2012a: fig. 11, 2018a; Fraaije et al. 2013; Starzyk 2013, 2015a, 2016; Robin et al. 2015; Krobicki \& Zatoń 2016; ).

Tanidromites comprises a diversity of forms, reflecting a complex ecology (sponge and coral reefs), with many modes of life proposed (Starzyk 2015a, 2016). Tanidromites richardsoni was held to be the oldest known member of the genus (see also Schweigert \& Koppka 2011: fig. 5; Krobicki \& Zatoń 2016: 707, fig. 6C, table 1) until T. maerteni Fraaije, Van Bakel, Guinot \& Jagt, 2013 (Fraaije et al. 2013: fig. 1) from the lower upper Bajocian of France was recorded. Today, the oldest tanidromitid is Gabri- 

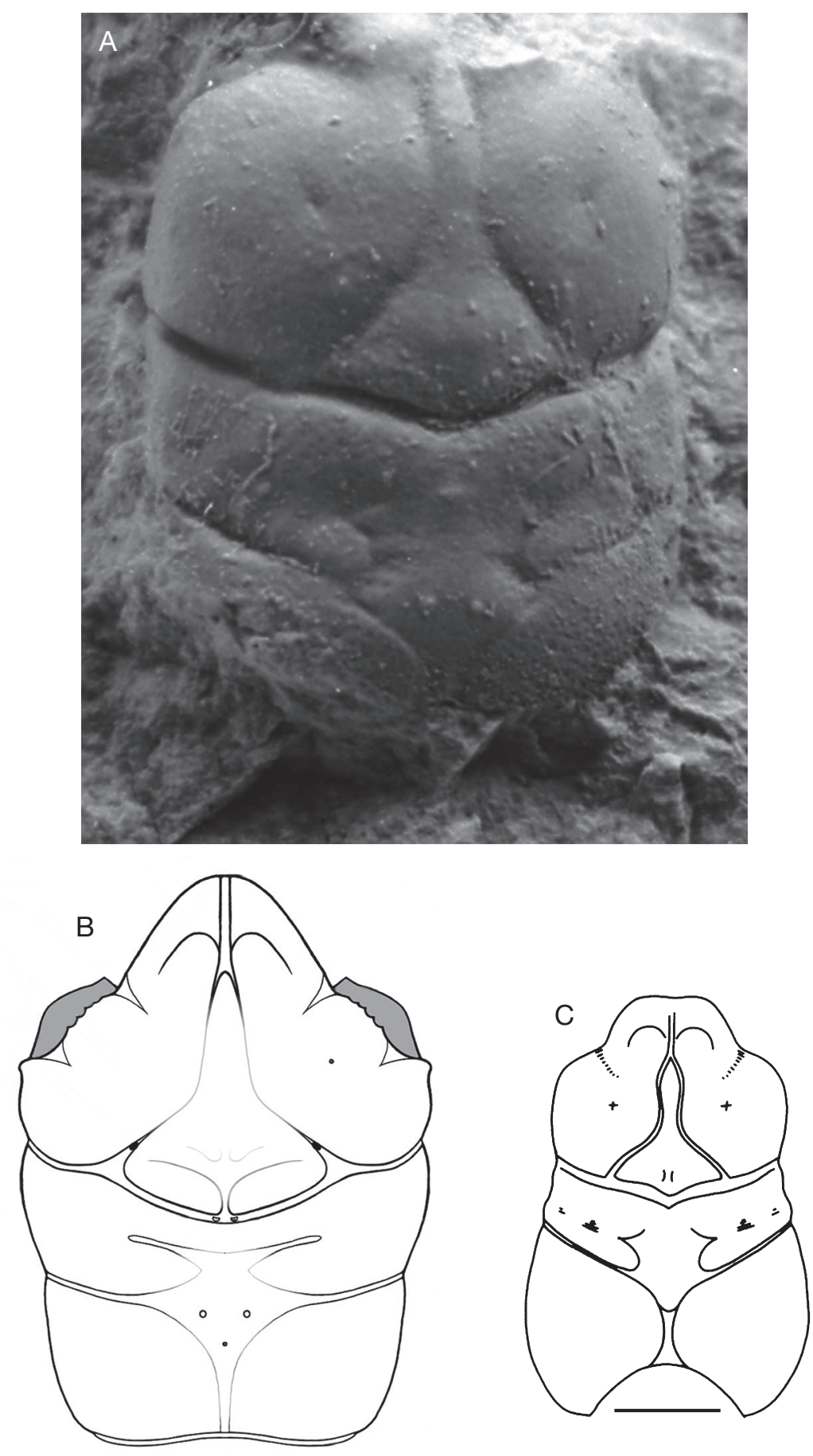

FIG. 16. - Tanidromitidae Schweitzer \& Feldmann, 2008: A, B, Gabriella biburgensis (Wehner, 1988); A, holotype, Germany, Biburg bei Weissenburg, Oxfordian (BSP-1980 XXX 514); B, reconstitution of carapace (both after Wehner 1988: pl. 1, figs 7 and 9a, respectively, as Foersteria biburgensis); C, Tanidromites: groundplan based on T. alexandrae Starzyk, 2015 (after Starzyk 2016: fig. 1, courtesy of Palaeontologica Electronica). Scale bar: C, 5 mm.

ella lugobaensis (Förster, 1985), from the upper lower Bajocian (Krobicki \& Zaton 2016: 697), which has a very simple orbital area (Starzyk \& Krzemińska 2019). Tanidromites aff. richardsoni, described by Franțescu (2011: 284, fig. 10), is of late Oxfordian to early Kimmeridgian age. Starzyk (2013: 176, figs 2-8; 2016: 12, fig. 1) observed that the shape of the "cervical pits" positioned in the middle of the cervical groove and varying amongst species of Tanidromites was a feature of taxonomic value.
The various published diagnoses of the Tanidromitidae and Prosopidae are seen to be insufficient, occasionally conflicting with each other, and also overlapping, in part. According to Fraaije et al. (2013: 252) the diagnoses of the families Tanidromitidae by Schweitzer \& Feldmann (2009c: 2) and Prosopidae by Schweitzer \& Feldmann (2009a: $65)$, respectively, are similar, the only difference being the presence of a biconvex posterior margin in the latter. The 

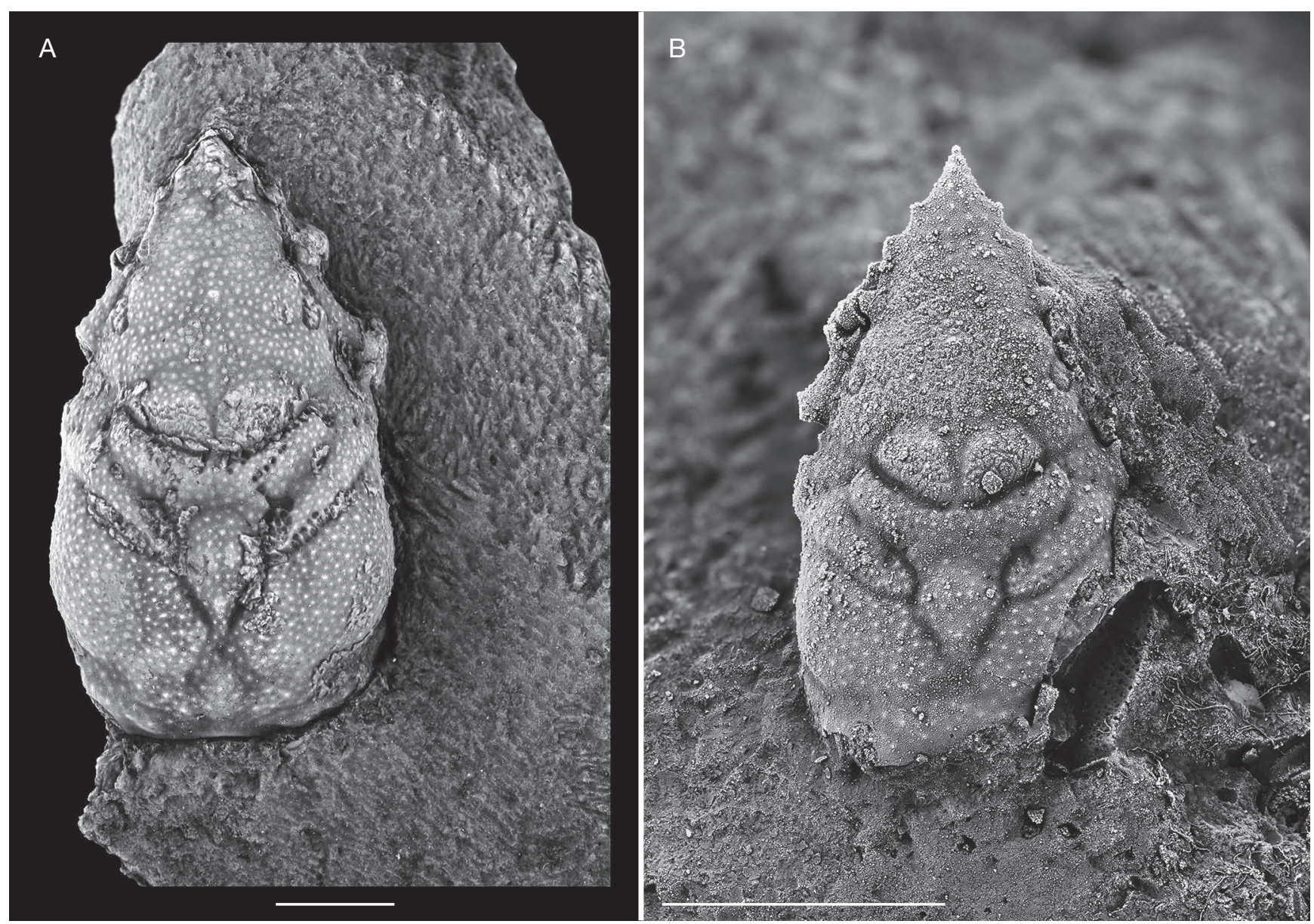

FlG. 17. - Viaiidae Artal, Van Bakel, Fraaije, Jagt \& Klompmaker, 2012: A, B, Viaia robusta Artal, Van Bakel, Fraaije, Jagt \& Klompmaker, 2012, Spain, Navarra, quarry of Monte Orobe, Albian-Cenomanian reefal limestones; A, holotype, $28.8 \times 15.8 \mathrm{~mm}$ (MGSB75298); B, paratype, $10.4 \times 5.8 \mathrm{~mm}$ (MABk3200) (after Artal et al. 2012: figs 1.3 and 2.3, respectively. Photographs courtesy of B. van Bakel. Scale bar: $5 \mathrm{~mm}$.

redescription of the type species Tanidromites insignis by Hyžný et al. (2011: fig. 2, table 1) and the discovery of homologous characters on dorsal carapaces have since clarified the status of the genus Tanidromites (Starzyk 2015a, 2016) (see Fig. 16C). Krobicki \& Zatoń (2016: 697), in describing a new species of Tanidromites from the Middle Jurassic, wondered if characters separating Tanidromites and Gabriella were reliable.

Gabriella sensu Collins et al. (2006), referred to the Tanidromitidae within the Homolodromioidea by Schweitzer $\&$ Feldmann (2008b), was restricted to species allied to the type species, G. biburgensi (Fig. 16A, B), by Schweitzer \& Feldmann (2009c: fig. 1.1), whereas others, formerly assigned to Prosopon, were placed in Planoprosopon Schweitzer, Feldmann \& Lazăr, 2007 of the Longodromitidae within the Glaessneropsoidea (see above, under Longodromitidae).

In describing Gabriella biburgensis, and translating Wehner's text (1988: 34, fig. 9, pl. 1, figs 7-9), Schweitzer \& Feldmann (2009c: 12, fig. 1) used the term "pores" for "gastric pits", i.e., the marks of attachment of the epimeralis attractor muscles, usually located at the level of the cervical groove (although depending on interpretations of grooves; see Guinot 1979: 37-46, fig. 7, "fossettes gastriques" in French).
However, they also referred to several small protusions on the dorsal surface as "pits", a term usually meaning a hole or a fossa. In my opinion, the term "pit" would need to be restricted to the shallow depressions that are also referred to as gastric pits or cervical pits.

Family VIAIIDAE

Artal, Van Bakel, Fraaije, Jagt \& Klompmaker, 2012

(Fig. 17)

Type Genus. — Viaia Artal, Van Bakel, Fraaije, Jagt \& Klompmaker, 2012 (type species by original designation: V. robusta Artal, Van Bakel, Fraaije, Jagt \& Klompmaker, 2012: figs 1, 2, from the Lower Cretaceous [Albian] to Upper Cretaceous [Cenomanian]).

InCLuded GeNerA. - Heeia Wright \& Collins, 1972 (type species by original designation: Prosopon villersensis Hée, 1924, from the Upper Cretaceous [Cenomanian]).

\section{REMARKS}

These two remarkable genera, of Early and early Late Cretaceous age, were tentatively placed in the Glaessneropsoidea by Artal et al. (2012: figs 1,2) on the basis of a combina- 

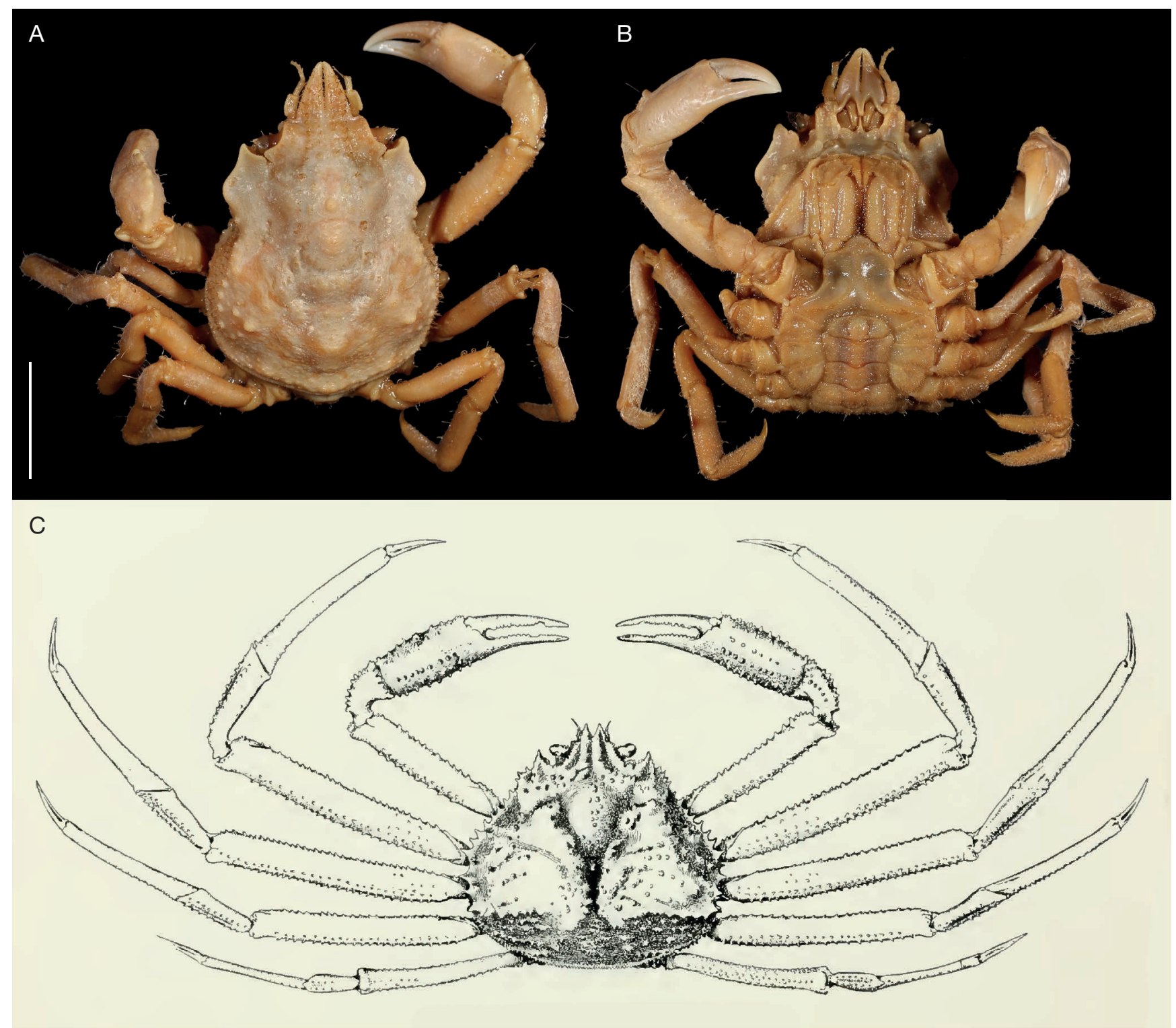

FIG. 18. - Majoidea, Oregoniidae Garth, 1958, extant: A, B, Hyas coarctatus Leach, 1814, North Atlantic, West coast of Iceland, Expediton Pourquoi-Pas ?, 1912, Bouvier det., male $27 \times 20$ mm (MNHN-IU-2014-23571); A, dorsal view of carapace; note alate hepatic regions; B, ventral view; C, Chionoecetes tanneri Rathbun, 1893, holotype, male, 119 mm cl (USNM15860), California, Gulf of the Farallones (after Rathbun 1893: pl. 4, fig. 1; 1925: pl. 234), dorsal view; note reduced P5. Scale bars: A, B, $10 \mathrm{~mm}$.

tion of characters deemed unique amongst Brachyura: an extremely elongate and slender body with a long, narrow frontal region, especially in Heeia (formerly assigned to the Latreilliidae; see Wright \& Collins 1972); a large, elaborate complex cavity dividing the lateral margins of the carapace and surrounded by nodes; a branchial groove that bounds the posterolateral margins of the cardiac region reaching the intestinal area; relatively large, complete orbits; and a concave and axially rimmed posterior margin that extends slightly on each side along the posterolateral carapace margin (Artal et al. 2012: figs 1.1, 1.5 for Viaia robusta, 2.1, 2.5 for Heeia villersensis); see also Schweitzer et al. (2012a: fig. 16). New specimens of Viaia robusta (Klompmaker 2013: fig. 10), from the same geological horizon and with a similar carapace arrangement, are indicative of a reefassociated crab.

Artal et al. (2012) did not find affinities with the Majoidea (and, in particular, with the Priscinachidae Breton, 2009), nor with the Latreilliidae (within the Homoliformia Karasawa, Schweitzer \& Feldmann, 2011, synonym of Homolidea sensu De Haan [1839]; see Guinot et al. 2013: 300). In comparing Heeia with Belos Franțescu, 2014 (type species by original designation: B. trispinae Franțescu, 2014, from the upper Albian), the first recognised fossil latreilliid (i.e., the Latreilliidae date back to the Lower Cretaceous) and with a preserved thoracic sternum, Franțescu (2014: fig. 8) agreed with a non-latreilliid assignment for Heeia. 


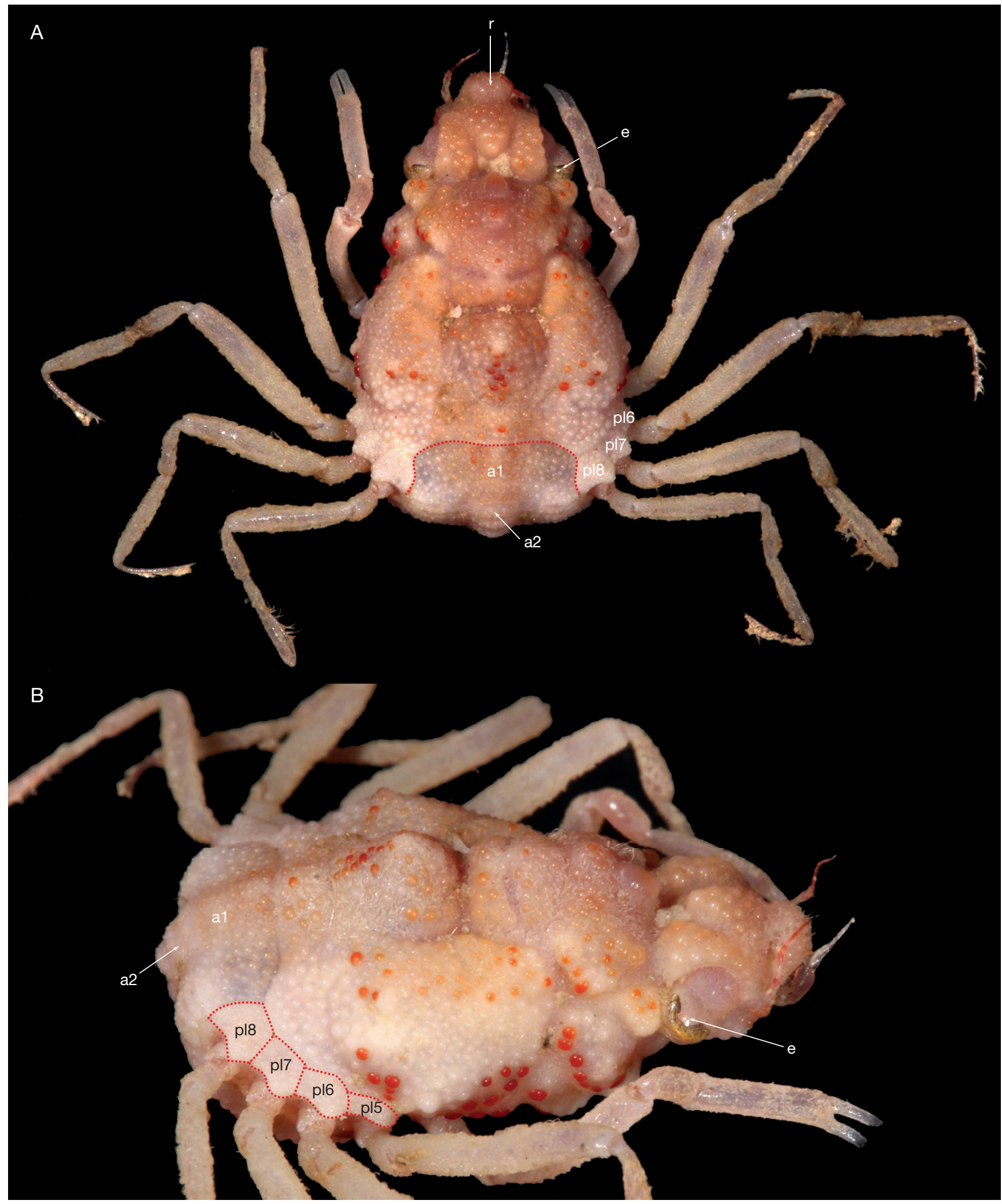

FIG. 19. - Majoidea, Inachoididae Dana, 1851, extant, Esopus crassus A. Milne-Edwards, 1875, female $10.5 \times 6.3$ mm, Guadeloupe, S Marie-Galante, KARUBENTHOS 2, stn DW4638, 312-305 m, Poupin \& Corbari det. (MNHN-IU-2013-19150): A, lobulated carapace, front as large, tuberculiform prominence (pl5 not indicated); B, lateral view. Abbreviations: a1, first male pleonal somites integrated into carapace; a2, second male pleonal somites; e, eye retractile in postorbital cup; pl5-8, exposed pleurites 5-8 forming kind of collar all around carapace posterolateral margin; $\mathbf{r}$, rostrum. The contour of carapace, pleurites and pleon (a1) has been highlighted by a red dotted line. Photograph courtesy of Joseph Poupin/MNHN. 


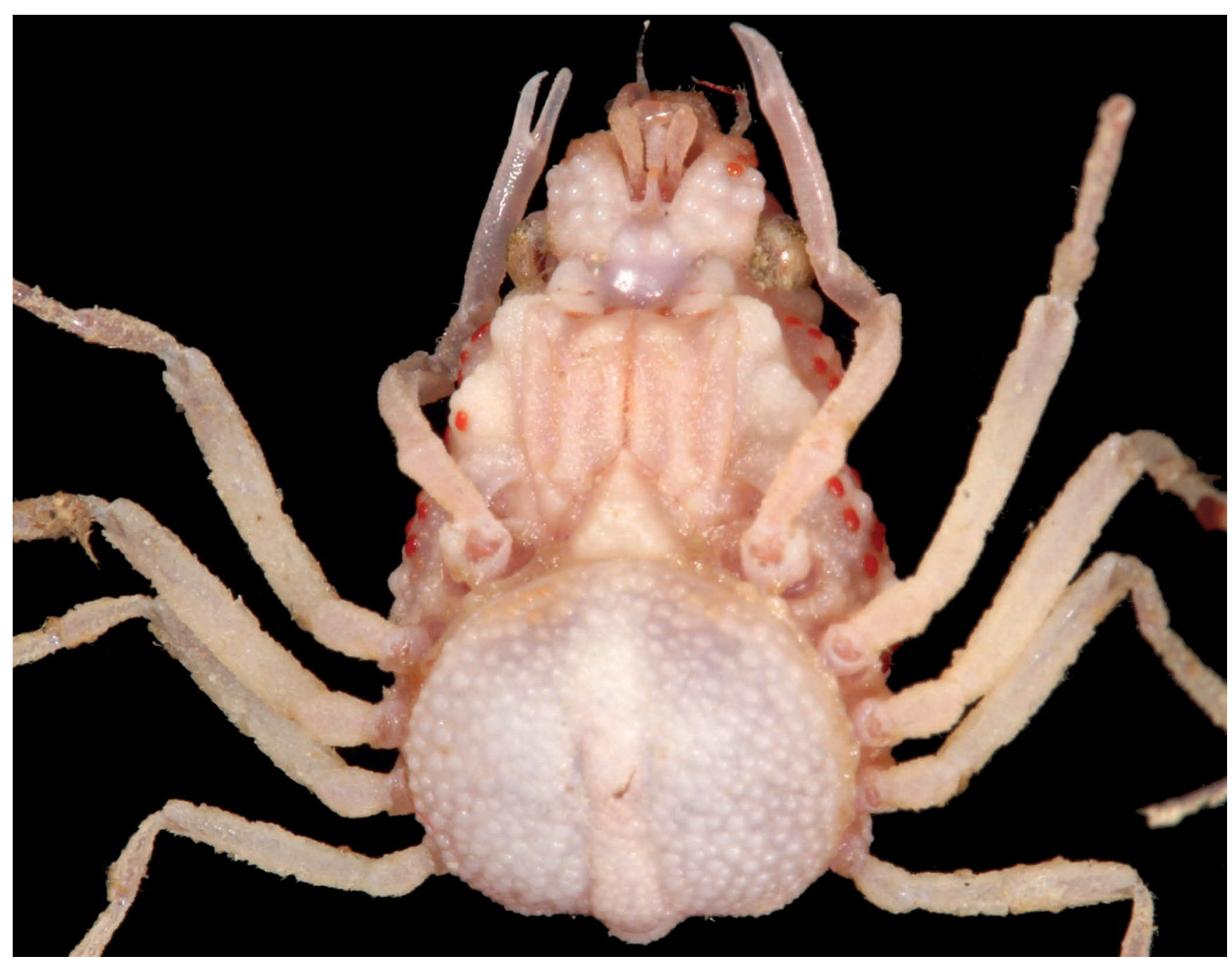

FIG. 20. - Majoidea, Inachoididae Dana, 1851, extant. Esopus crassus A. Milne-Edwards, 1875, ovigerous female $10.4 \times 6.3 \mathrm{~mm}$, same data as Fig. 19 : ventral view, brood chamber closed like a box, pleon as large, discoid plate. Photograph courtesy of Joseph Poupin/MNHN.

In my view, the wide flange of the concave posterior margin of the carapace that extends slightly along the posterolateral margin of Viaia robusta (Fig. 17A) is a significant character of the family. This disposition was described well for Heeia villersensis by Wright \& Collins (1972: 32, fig. 5, pl. 3, figs 1-4, pl. 22, figs 3, 4): "the posterior margin is wide with a rounded ridge and has five distinct facets", a trait well visible in the reconstitution of the species (their fig. 5) and seen only in the specimen of their plate 22, figure 4c. Artal et al. (2012: 399), in the family diagnosis, noted "posterior margin short, nearly straight, bounded laterally by small concavities", and in the description of Viaia robusta "lateral angles of the posterior margin [are] bounded by notable concavities", a disposition clearly visible in their figures 1.1 and 1.5, and in Heeia villersensis figured fig. 2.1 and 2.4. The authors explained that the concavities and nodes developed on the lateral borders of the carapace of Viaia were not an exclusive feature of the genus, because similar structures had been noted in Lecythocaris, Ekalakia and Nodoprosopon. In the Dromiidae, the deep subbranchial concavity present in the extant genus Speodromia Barnard, 1946 (Ng 2016) does not appear to be homologous.

I concur with Artal et al. (2012: 400) that assignment of Viaia to the Lecythocaridae (Fig. 10) (see above) is not suitable. Their discussion on the features that distinguish the Viaiidae from other glaessneropsoids and especially from Nodoprosopidae (Fig. 14) (see above) highlighted certain points that serve as a novel basis for for addressing the issue of earliest crabs.

\section{DISCUSSION}

Our science, i.e. taxonomy, systematics and classification, is based on observation of specimens and on descriptive, explanatory and, above all, predictive concepts, especially where fossil animals, often fragmentary, are concerned. Our classification and nomenclature should be seen as a step in advancing our knowledge, rather than as an achievement; each of these steps will, sooner or later, be replaced by a 
better one, or one considered to be so. According to the French philosopher Bachelard (1938, La formation de l'esprit scientifique), we cannot base anything on opinion: we must first destroy it. Such is the first obstacle to overcome; first of all, we must be able to pose problems. It is precisely this sense of the problem that marks the true scientific spirit. Our knowledge needs to be questioned, and preconceived ideas must be challenged, which I am trying to do here with great humility. However, we must avoid writing and publishing papers that are hasty, premature and with contradictory changes from year to year, which all leads to unsatisfactory results that will have to be adjusted constantly.

All of the above proposals imply high-risk bets, since they are inevitably based on provisional assumptions, until features of preserved ventral parts and pereiopods prove or refute them, either wholly or in part. Neontologists, likewise, too often rely solely on the carapace and limbs, despite the fact that, unlike palaeontologists, they have access to the "ventral" characters in most cases. It should be borne in mind that my predictive proposals are by no means criticism of palaeontologists who are morphologists par excellence, and their knowledge is a priority to this field of research. That fossil character data can make significant contributions to phylogenetic reconstructions, which until recently were more art than science, is now evident. Palaeobiology and neontology are poorly integrated, but, whereas the palaeontologists integrate data gained from extant taxa, neontologists often ignore fossil data. Fossil specimens most likely represent exuviae and casts or are disarticulated and fragmentary. In Solnhofen-type lithographic limestones brachyuran remains are extremely rare (Schweigert 2011). Near-perfect fossilisation of the earliest brachyurans, such as the eubrachyurans Archaeochiapasa mardoqueoi from the Cenomanian El Chango Lagerstätte of Chiapas, Mexico (Guinot et al. 2019) and Telamonocarcinus gambalatus Larghi, 2004 from the Cenomanian of Lebanon (Larghi 2004: 539, figs 5, 6, 7.2-7.8; Garassino et al. 2008: 61; Luque 2015b: fig. 2B; Charbonnier et al. 2017: 207, figs 451-469), and the podotreme Araripecarcinus ferreirai Martins-Neto, 1987 from the Albian Araripe Basin of northeastern Brazil (Luque 2015a: fig. 1A, B), is exceptional. In order to be able to examine the ventral parts, the specimens must be carefully prepared with needles and scalpels under a stereomicroscope, with a constant risk of damage.

With the carapace alone it is extremely difficult to evaluate brachyuran characters as a whole, to recognise apomorphies, to interpret if the shared characters are the result of convergence or not, to judge if a group of genera may be assigned to a known superfamily (with all the imperfections and constraints at this level) or to assume that a novel combination of characters may be representative of a new lineage. Due to the partial analysis of characters in Jurassic decapods, the main inferences of their phylogenetic relationships can be based exclusively on carapace features and the shape of groove patterns. An inherent problem with all classifications is that each superfamily or family shares similar plesiomorphic characters, making it difficult to identify structures correctly and search for synapomorphies.
It is definitely challenging to research if the geological range of Eubrachyura should be extended downwards with confidence into the Jurassic. Due to the extreme and complex diversity shown by the earliest crabs, where to set the crucial time in the evolution of the brachyuran clade? Guinot \& Tavares (2001) suggested that the Podotremata/Eubrachyura clades separated at some time prior to the Jurassic but that no fossil eubrachyuran had yet been interpreted prior to the Early Cretaceous. How can we move away from the traditional, and current, assumption accepted by all (Schweitzer \& Feldmann 2005: tables 1, 4, 5; 2015: 633, fig. 1, table 3C; Jagt et al. 2015; Davie et al. 2015b) that the first eubrachyurans did not appear until the Early Cretaceous? Some presumed podotreme crabs from the Jurassic and Cretaceous actually may well be eubrachyurans (heterotremes), which is why I do not agree with the statement by Schweitzer \& Feldmann (2015: 637) that heterotreme crabs "appeared in the Early Cretaceous". Thus, the history of Jurassic crabs becomes even more fascinating.

A character that has especially drawn my attention is the depressed area in front of the posterior margin of the carapace that is referred to as "flange" in the Archaeochiapasidae (Guinot et al. 2019: figs 7, 8, 9B, 12A, C), and, when present in some other taxa, has been described as a "rim" by various authors. I am relatively confident of the homology of this special structure that is found in several Jurassic and Cretaceous families (but, apparently, is never present in extant brachyuran taxa). I shall use, for the sake of convenience, the term "flange" for all, whether it is narrow or wide, shallow or deep, short or extending along the posterolateral border of the carapace. It is implemented when the posterior margin is deeply concave, so the aspect of the structure is biconcave (Archaeochiapasidae: Fig. 1B, D; Lecythocaridae: Fig. 10; Nodoprosopidae: Fig. 14) and even termed "biconvex" (Vectis: Fig. 8A), and when it is nearly straight/straight (Glaessneropsis: Fig. 7A-C) or convex (Rathbunopon: Fig. 8B, C; see also Klompmaker et al. 2011a: fig. 4). However, it is advisable not to generalise because a concave rimmed margin occurs in species that appear to be undoubted podotremes such as Longodromites angustus, L. excisus (Fig. 11A, B, D) or Eodromites grandis (Fig. 5D). But, when other characters (i.e., sulcate rostrum; swollen hepatic areas; inflated branchial regions with narrow, or even absent, interbranchial space; long and oblique branchiocardiac groove; well-defined cardiac region extending near the carapace posterior margin) are combined with the rimmed flange, they become reliable indicators with a new perspective.

Although conclusions cannot be based solely on a particular configuration, the only available data are currently insufficient to allow a "definitive" assignment. I shall examine taxa that may be candidates to become hypothetical eubrachyurans, similar to the Archaeochiapasidae, and then redefine those taxa that remain true podotremes. My proposals are essentially based on the type species of genera, hence in the case of non-monophyletic families all species included should be carefully revised. 


\section{PRESUMED EUBRACHYURANS}

The first candidate for possible affiliation to the Eubrachyura is the family Lecythocaridae (Fig. 10A-D), which for the moment only includes diminutive species, of Late Jurassic and Cretaceous age. Amongst others, several characters such as the alate hepatic regions, expanded branchial regions and shape of the cardiac area are shared with the Archaeochiapasidae. The triangular outline of the carapace and other traits of lecythocarids are quite reminiscent of the Majoidea, and there is conclusive evidence to advocate for a eubrachyuran, majoid affiliation, namely with the extant family Oregoniidae (Fig. 18A-C).

The superfamily Majoidea, with its outstanding diversity, raises some of the most interesting problems for studies on brachyuran phylogeny. Based on a molecular estimates of decapod phylogeny, Porter et al. (2005: fig. 2) and Crandall et al. (2009: fig. 2) recovered the Majoidea as the oldest brachyuran lineage, with a divergence time from other brachyurans of approximately 254 million years, i.e., Late Permian (however, their both figures 2 show this to be in the Middle Triassic; see Wolfe et al. 2019; Colavite et al. 2019), In addition, all data, spermatozoal (Tudge et al. 2014), larval (Rice 1980, 1981, 1983, 1988; Clark \& Webber 1991; Pohle 1991; Marques \& Pohle 1998, 2003; Pohle \& Marques 2000) and genetic (Ahyong et al. 2007; Hultgren et al. 2009), are congruent in substantiating the Majoidea as a deeply rooted lineage, with the Macrocheiridae Dana, 1851 (type species: Macrocheira De Haan, 1839) the more basal (Clark \& Webber 1991). The phylogenetic molecular trees of Tsang et al. (2014: fig. 2) and Chu et al. (2015: fig. 71-13.2) supported majoids to be amongst the most basal eubrachyurans, although with obscure phylogenetic positions. The Oregoniidae, here exemplified by the boreal genus Hyas and by Chionoecetes tanneri (Fig. 18C), is considered a basally branching family and the only majoid group that has been unambiguously resolved as monophyletic (Hultgren et al. 2009; see also Chen et al. 2019: fig. 3). Another deeply rooted branch in the eubrachyuran phylogenetic tree (Ahyong et al. 2007; Chu et al. 2015) is the superfamily Dorippoidea MacLeay, 1838, with Telamonocarcinus antiquus Luque, 2015 (Luque 2015b: fig. 2A), from the upper Aptian-lower Albian of Colombia, and with the recently described Eodorippe connori Nyborg, Garassino, Vega \& Kovalchuk, 2019, from the Albian of Oregon (Nyborg et al. 2019: fig. 5). But no Jurassic crab is reminiscent of a dorippoid.

Other candidates that could turn out to be possible eubrachyurans are two families, both established in the same paper (Schweitzer \& Feldmann 2009a: table 1), but assigned to two distinct superfamilies. To the Homolodromioidea, was assigned the family Bucculentidae from the Upper Jurassic (Bucculentum, Oxfordian, Kimmeridgian, Tithonian, Fig. 2A-C) and Cretaceous (Wilmingtonia, Cenomanian, Fig. 2D). The monotypic Late Jurassic Nodoprosopidae (Nodoprosopon, Kimmeridgian-Tithonian, exemplified by its type species N. ornatum (Fig. 14A, B), was assigned to the Glaessneropsoidea. These two families are very close, as can be judged by their rather similar diagnoses (Schweitzer \& Feldmann 2009a:
61-62, key; Schweitzer et al. 2012a). The only important difference could be the absence in the Nodoprosopidae of "well-defined orbits or reentrants in which the eye can rest" (perhaps due to preservational bias), so that its placement within the Glaessneropsoidea was considered somewhat problematic (Schweitzer \& Feldmann 2009a: 117). Substantial similarities include the elongate carapace, the inflated hepatic regions, the strongly marked and oblique branchiocardiac groove, the concave posterior margin of carapace, and the flange. All species are tiny. Nodoprosopon ornatum (Fig. 14A, $\mathrm{B})$, "unique in possessing a distinctive trifid rostrum and overall triangular carapace" (Karasawa et al. 2011: 538) (but note the trifid rostrum of Bucculentum, see Fig. 2C here), is reminiscent of majoids. Protuberosa protuberosa (Fig. 15B) appears to be related to the bucculentids and could be a presumed eubrachyuran.

Can the Albian/Cenomanian family Viaiidae, tentatively assigned to the Glaessneropsoidea, also be a eubrachyuran candidate? The flange that extends on each side along the posterolateral carapace margin is reminiscent of the condition found in Archaeochiapasa (Fig. 1B, D). According to Artal et al. (2012: 404, 405), the resemblance to the Majoidea was only superficial. In fact there is no extant majoid that could accommodate the family. I agree that in Viaia robusta (Fig. 17A, B) the same location for antennules, antennae and eyestalks corresponds to a plesiomorphic state. The comprehensive discussion by those authors highlights an interesting point: the cavities surrounded by nodes in the lateral sides of the carapace at the level of the cervical groove, an important characteristic of Viaia, may be compared to fairly similar structures in Lecythocaris and Nodoprosopon, as seen in illustrations supplied by Schweitzer \& Feldmann (2009a: figs 6 and 10, respectively). Like the Lecythocaridae and Nodoprosopidae, presumed eubrachyurans above, could not the Viaiidae be non-podotreme as well?

The four families included in the Glaessneropsoidea by Schweitzer \& Feldmann (2009a: table 1) and Karasawa et al. (2011: table 1), i.e., the Glaessneropsidae, Lecythocaridae and Nodoprosopidae might all be eubrachyurans. As a result, if confirmed non-podotreme, the superfamily Glaessneropsoidea would be included in the Eubrachyura. The Lecythocaridae and Nodoprosopidae could be reasonably included in the Majoidea. Within the Glaessneropsidae, some genera such as Glaessneropsis (Fig. 7A-C) and Verrucarcinus (currently under study) are exclusively of Jurassic age; others such as Ekalakia (Fig. 7D), Rathbunopon (Fig. 8B, C) and Vectis (Fig. 8A) are exclusively Cretaceous in distribution

The case of the genus Rathbunopon, so thoroughly revised by Klompmaker et al. (2011a), is particularly vexing: if it is a eubrachyuran, I am not able to identify a family likely to accommodate it, and this highlights the high degree of speculation of my hypotheses.

At first glance, these questionable crabs do not appear to have known relatives in extant faunas. However, the mesograzer majoid Leucippa pentagona H. Milne Edwards, 1833 (Epialtidae MacLeay, 1838) (see Rathbun 1925: 184, 222, pls 61, figs 7-9), although with a different carapace dorsal 
surface, has a wide rostrum that extends well beyond the orbits, somewhat reminiscent (but without keels) of that of Glaessneropsis heraldica (Fig. 7A-C). Other majoid crabs such as Mocosoa crebripunctata Stimpson, 1871 (Rathbun 1925: 159, pl. 49, figs 3, 4), with sulcate dorsal surface and large eyes, and species of Microlissa Pretzmann, 1961 (as Lissa in Rathbun 1925), such as M. bicarinata (Aurivillius, 1889) (Fig. 21), exhibit projected and truncate rostra.

Extraordinarily large eyes (relative to body size), characteristic of Ekalakia (Fig. 7D), may be found in the Recent Majoidea, which shows a great diversity in the construction of orbits and eyes. It is interesting to point out here the case of a rare and small extant species from the eastern Atlantic, Esopus crassus A. Milne-Edwards, 1875. This has a thick, lobulated oval carapace; a rostrum that forms a tuberculiform, rounded prominence; and stout, short eyestalks located in post-ocular cups (Fig. 19A, B) (A. Milne-Edwards 1875: 90, pl. 17, figs 1, 1b, 2c; Rathbun 1925: 192, pl. 222, figs 10-12; Carmona-Suárez \& Poupin 2016: 384; Poupin \& Corbari 2016: fig. 15k; Poupin 2018: 184, fig. 198). The narrow body shape and lobulated, grooved carapace, rather unusual in the Majoidea, are reminiscent of some shapes found in the earliest crabs. In fact, the monotypic genus Esopus A. Milne-Edwards, 1875 does not belong to the Epialtidae MacLeay, 1838 as in the current classification ( $\mathrm{Ng}$ et al. 2008: 100). It must be assigned to the Inachoididae Dana, 1851, a rather basal family within the Majoidea and with members recorded exclusively from the Miocene onwards, instead of Eocene (Feldmann \& Schweitzer 2004). Inachoidids are characterised by "integration" of the wide and dorsal first male pleonal somite to the carapace (thus seemingly part of carapace), by exposure of the latero-external portions of pleurites 5-8 that, calcified and ornamented like the dorsal surface, extend beyond each side of carapace in forming a kind of collar all around its posterolateral margins; by a pleotelson (pleonal somite 6 fused to telson); and by a brood chamber that is closed like a box by the enlarged pleon (Fig. 20) (see Guinot 2012: figs 1-3; Guinot et al. 2019: fig. 16A, B). This disposition is found in several American taxa, such as Paradasygyius depressus (Bell, 1835), Paulita tuberculata (Lemos de Castro, 1949), Batrachonotus fragosus Stimpson, 1871, species of Euprognatha Stimpson, 1871, in which the broad first male pleonal somite looks as it is embedded into the carapace (Rathbun 1925: pl. 39; Santana 2008: figs 7C, 10A). Esopus offers the typical inachoidid organisation, the pleon and pleurites significantly increasing the surface area of the "carapace", but differs from others inachoidids by the the short eyestalk included in the orbit, without detached and developed postorbital tooth, the rostrum strongly deflexed and produced downwards in the shape of a salient, thick beak-shaped plate joining the epistomial process (manuscript submitted).

In contrast to the Glaessneropsidae, the family Longodromitidae, also first included in the Glaessneropsoidea but later reassigned to the Homolodromioidea (Schweitzer et al. 2012a, 2018b), is, in whole or in part, podotreme, and can be placed within the Dynomeniformia.
In conclusion, most of these presumed eubrachyurans (the vast majority of which are very small, even diminutive, e.g., lecythocarids) are more or less similar to the large group of the Majoidea, but it is too early to draw any firm conclusions. All of them probably belong to extinct families. Some families are certainly monophyletic (i.e., Lecythocaridae, Nodoprosopidae), whereas members of the Bucculentidae and Glaessneropsidae warrant re-eavalution. Actually, a review of all these presumed eubrachyuran species and, in addition, of some imperfectly known "prosopids" is called for. Comparisons with the Micromaiinae Beurlen, 1930 (type species: M. tuberculata Bittner, 1875 from the Middle Eocene; see Hyzny \& Zorn 2016: pl. 6, figs. 1-8; see also Beschin et al. 2012) and with Planobranchia Schweitzer \& Feldmann, 2010 from Eocene rocks (see Schweitzer \& Feldmann 2010f: fig. 2A; Feldmann et al. 2011: fig. 5; Artal et al. 2014: pl. 1) should be interesting. In addition, a new comparative review of all fossil majoids may prove useful.

Will the wide thoracic sternum of the Archaeochiapasidae be present in these families? Bucculentids, lecythocarids and nodoprosopids may possess a wide thoracic sternum, such as the majoids. The glaessneropsids, with rather broad bodies, may also display a wide thoracic sternum, while narrow genera as Viaia may seem problematic at first sight. However, this may not be the case at all. Small, narrow- bodied Recent majoids of the subfamily Podochelinae Neumann, 1878, called "neck crabs", exhibit very wide sternal plates, as shown by the ventral views of species of Podochela sensu Rathbun (1925: pls 11-21), now reassigned to several genera (Guinot 2012). Species of Stenorhynchus Lamarck, 1818 with extremely long rostra and narrow bodies (Inachoididae Dana, 1851 and Stenorhynchinae Dana, 1851), also have a wide thoracic sternum (see Rathbun 1925: pl. 3; Guinot 2012).

A comparison of the Archaeochiapasidae with the Cretaceous and extant eubrachyuran families was made by Guinot et al. (2019). A novel study of the taxa referred to above would certainly be fascinating to both palaeontologists and neontologists

\section{PODOTREME CRABS}

The other families here analysed are unambiguous podotremes and belong to the Dynomeniformia (however, species included need to be revised). Their origin is certainly more ancient than that of the presumed eubrachyurans mentioned above.

The Homolodromioidea, the oldest brachyuran lineage (with, probably, also the Homoliformia), includes the Homolodromiidae. To date, Homolodromiidae (Fig. 9) comprises a relatively small number of extinct genera: the earliest known, Eoprosopon (provided that it is a true homolodromiid) from the Lower Jurassic (upper lower Pliensbachian) and Homolus from the Middle Jurassic (Bathonian), and others such as Antarctidromia from the Lower Miocene (see Schweitzer et al. 2012a: 9). The family originated earlier, for example with reference to the mobile, dorsally carried, subchelate P4 and P5. The acquisition of such specialised structures inevitably required a long process involving several adjustments: amongst others, increased mobility of the legs at the 
articulation on the thoracic sternum (i.e., a particular shape of the P4 and P5 coxo-sternal gynglymes that receive the P4 and P5 coxo-sternal condyles, which allows a more ample movement of the coxae; see Guinot et al. 2013: fig. 62C, D for the P5 of a homolid).

The genera of Dromiidae (within the Dromioidea) may be distributed in Basinotopinae (Fig. 3), Dromiinae (Fig. 4), Sphaerodromiinae (Fig. 6) and Goniodromitinae sensu stricto (Fig. 5E).

Goniodromitidae of most authors is removed from the Homolodromioidea (compare Wright \& Wright 1950) and relegated to subfamily rank, Goniodromitinae, within the Dromiidae. Its current composition is characterised by great confusion and paraphyly. The status of many genera previously regarded to be homolodromioids and goniodromitids, such as Distefania (Fig. 6B-D), Eodromites (Fig. 5D) and Palaeodromites, is in need of reappraisal, with a reassessment of their suprageneric placement, perhaps to the Sphaerodromiinae or even to the Dynomenidae. The Sphaerodromiinae, which cannot be relegated to subfamily rank (Not in agreement with Schweitzer \& Feldmann [2010d], Karasawa et al. [2011], Schweitzer \& Feldmann [2012a, b] and Schweitzer et al. [2012a]), could also include Dromilites (see Van Bakel et al. 2017; Robin et al. 2017) and Ferricorda, the latter known by carapaces and pereiopods (Landman et al. 2014: fig. 4).

Prosopidae, in which are included Acareprosopon, Laeviprosopon, Nipponopon and Prosopon, is probably not monophyletic and must be probably restricted. A revision of the genera included and all species would be welcome. I suggest removing Protuberosa (Fig. 15B), which looks like a bucculentid, from the Prosopidae.

Tanidromitidae, one of the oldest brachyuran families (of Bajocian age), is represented by the well-defined Tanidromites (Fig. 16C) (Fraaije et al. 2013; Robin et al. 2015; Starzyk 2015a, 2016; Krobicki \& Zatoń 2016), likely a podotreme. Gabriella sensu Collins et al. (2006), referred to the Tanidromitidae within the Homolodromioidea by Schweitzer \& Feldmann (2008b), is restricted to species allied to its type species, G. biburgensis (Fig. 16A, B).

The case of the Longodromitidae is confusing. The type species of Longodromites, L. angustum (see Hyzný et al. 2015), has been included either in the Homolodromioidea or in the Glaessneropsoidea, a seemingly paraphyletic superfamily. Some genera such as Abyssophthalmus (Figs 11C; 12A, B), Antarctiprosopon and Pilidromia actually look like homolodromioids, whereas Coelopus (Fig. 13A) deviates from the other genera and does not remind of a homolodromioid, but nevertheless does belong to the Dynomeniformia. Subject to verification of included genera and all characters, the podotreme Prosopidae and Tanidromitidae, as a whole or in part, might be included in the Homolodromioidea, unless some members can be included in the Dromioidea. It is also possible that some included genera/species could belong to the Homoliformia: crabs broken at the level of the lineae homolicae and only represented by the interlineal portion of the carapace must be taken into account.
The Konidromitoidea/Konidromitidae appears to be part of the Dynomeniformia within the Dromioidea and Dromiidae. Species are somewhat reminiscent of the extant dromiine Ascidiophilus (Fig. 4B, C), which lives in association with ascidians, a probably ancient behaviour.

Table 1 presents a tentative list that summarises the various assumptions presented here, awaiting the discovery of ventral parts to corroborate or refute these.

The STATUS OF THE FAMily Callichimaeridae LuQUe, Feldmann, Vernygora, SchWeitzer, Cameron, Kerr, Vega, Duque, Strange, Palmer \& Jaramillo, 2019

(Luque et al. 2019)

Preliminary note

Although D. Guinot's name appears in the acknowledgements of Luque et al. (2019: 14) "for early discussions", none of the authors asked my opinion on this fossil form that I see for the first time in this publication.

The discovery of dozens of exceptionally preserved "juvenile and adult specimens", males and females, of a very small species, Callichimaera perplexa Luque, Feldmann, Vernygora, Schweitzer, Cameron, Kerr, Vega, Duque, Strange, Palmer \& Jaramillo, 2019 (Luque et al. 2019), from the mid-Cretaceous (Cenomanian-Turonian) of Colombia and lower Upper Cretaceous of the United States, has recently led to the erection of a new genus, new family (Callichimaeridae Luque, Feldmann, Vernygora, Schweitzer Cameron, Kerr, Vega, Duque, Strange, Palmer \& Jaramillo, 2019) and superfamily (Callichimaeroidea) and, even, the creation of a new section, Callichimaeroida, in addition to the eight existing ones (see above, System of Luque et al. [2019: table S2]). It was considered "a unique lineage of ancient true crabs", with a "body plan that represents one of the most anatomically complete early crabs found to date" (Luque et al. 2019: 1, figs 1-4, 6.I, S4). The carapace width of the specimens measured -4 to $10 \mathrm{~mm}$, the body length 6.6 to $15.1 \mathrm{~mm}$.

A second family, the monotypic Retrorsichelidae Feldmann, Tshudy \& Thomson, 1993, from the James Ross Basin, Antarctic, monotypic with Retrorsichela laevis Feldmann, Tshudy \& Thomson, 1993 (Feldmann et al. 1993: figs 19, 20), was tentatively included in the Callichimaeroida. But its characters (carapace large, ovoid; eyes likely small and reduced; chela with fixed finger only slightly deflected downward; P2 and P3 positioned ventrally; thoracic sternites 5 and 6 similar) are markedly different from those of Callichimaeridae. In our opinion - and in the case of a true brachyuran nature of this family-, including (even tentatively) Retrorsichelidae in Callichimaeroida considerably weakens the argument of a "chimeric crab" for Callichimaeridae. The mention in Retrorsichela laevis of male gonopores "in posterolateral portions" of sternite 6 is puzzling. And the hypothesis of a postlarval stage should be ruled out due to the size of the species $(\mathrm{cl} 81.0 \mathrm{~mm}$; $\mathrm{cw} 60.9 \mathrm{~mm}$ for the largest specimen), the reduced eye, and the chela that is not spanner-like.

According to Luque et al. (2019: 4, 6, 8), "Callichimaera superficially resembles a larval stage known as a megalopa”. The reduced size, the narrow and elongate body, huge eyes and 


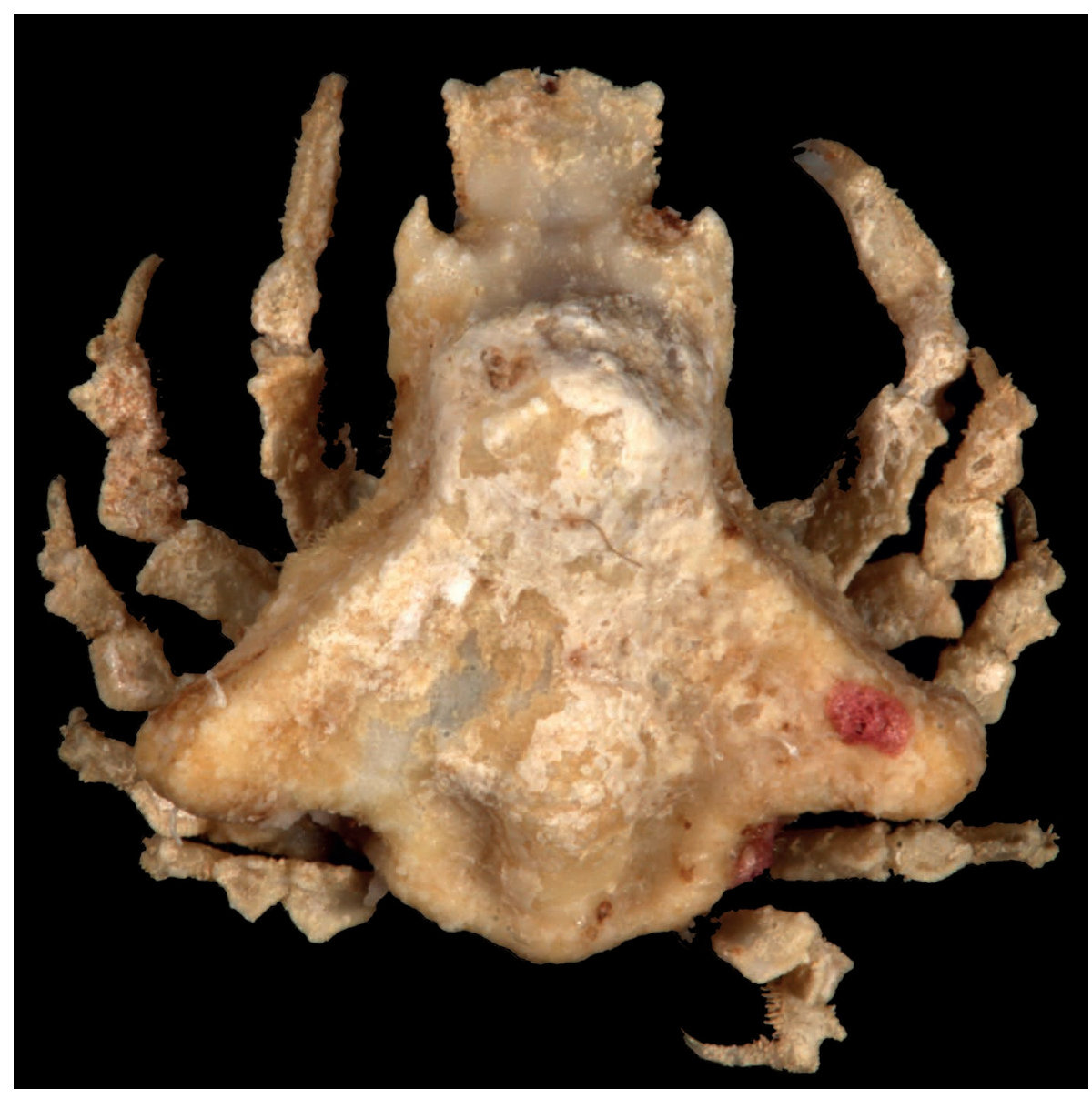

FIG. 21. - Majoidea, Epialtidae MacLeay, 1838, extant. Microlissa bicarinata (Aurivillius, 1889), male, Guadeloupe, Petite Terre, KARUBENTHOS 2012, stn GB32, $4 \mathrm{~m}$, C. Carmona-Suarez det., c. $9.5 \times 9.2 \mathrm{~mm}$ (MNHN-IU-2013-4446): see the projected and truncate rostrum. Photograph courtesy of Joseph Poupin/MNHN.

extended pleon reminded the authors "possibly a megalopa or early postlarval stage". But this hypothesis was rejected by the authors who adopted the idea of adults looking like megalopae or juveniles by retention of some juvenile traits in adulthood via paedomorphosis ("retention of juvenile characters of the ancestral forms by adults of their descendants") and heterochrony ("evolutionary change in the timing of the development of a character between an ancestor and descendant"; underdevelopment) (McKinney \& McNamara 1991; Clark 2009: 226, fig. 2; Clark \& Cuesta 2015: 1030, fig. 71-17.17). As morphological characters or events may occur at different times, i.e. at different stages, and/or may be expressed at different rates, the changes in the timing of developmental events or heterochrony occur very often, for example in the expression of pleopods (Anger et al. 2015).

Callichimaeridae is characterised by small size at maturity and by the presence of morphological features that are typically of those of the juveniles belonging to more basal species, however without being a duplicate form of the juvenile stages of more basal species. According to Landman et al. (1991: 409) paedomorphosis is produced by a number of processes, notably progenesis, which "involves the early offset of growth usually associated with the onset of sexual maturation and generally results in a smaller adult size and shorter generation time" (see also Gould 1977); progenetic species "resemble the juveniles of more primitive (outgroup) species" but, however, "commonly develop a number of unique features at maturity as well as those associated with the mature stages of more primitive species".

The discovery of Callichimaera perplexa leads us to some thoughts. Brachyura at a larval or post-larval phase are largely, if not completely unknown, in the fossil record, and everything remains to be learned about the development brachyuran stages as fossils. Only two cases of fossil zoeae are mentioned (Luque 2015a: fig. 6) and megalopae have been reported from the Solnhofen Lithographic Limestones, about 150 mya (Haug et al. 2015). In addition, there are no known reports of fossil crabs at postlarval instars, juvenile instars, which consist of gradual changes in the adult form, being more similar to the potential adult form than the preceding ones. And this is despite their potential considerable number, when we count the number of eggs laid by all individuals of all brachyuran species at each reproductive season, and in all the time since then! Luque et al. (2019) have not explored the possibility of crabs being at a instar after the megalopa: they only mention "postlarval stage" in the caption of the figure $3 \mathrm{G}$ representing a "very small individual", a paratype. In extant crabs, the sexual dimorphism can be shortly recognisable from the 
very early stages, thus rather long before the puberty moult, that is the definitive morphological condition of adult state and where maturity is initiated (Hartnoll 2015). Postlarval growth of crabs is made of a variable number of recognisable instars, either with little morphological difference between instars or with discriminating characters. In the illustrations adapted from litterature figured by Felder et al. (1985: figs 4-6) showing the early postlarval stages of diverse decapods, the form that looks more like C. perplexa is the "decapodid" (or megalopa) of Raninoides benedicti Rathbun, 1935 (see below). The number of instars, known or estimated, in the postlarval development, and the morphological changes during the postlarval ontogeny (scarcely investigated and acknowledged only for a limited number of Brachyura), vary depending on species but also on other factors (e.g. crabs reared in laboratory or in natural condition). In the benthic juvenile phase, the pleon is tucked beneath the thorax, the pleopods lost their swimming function and are modified in gonopods in males; the young benthic crabs pass through an extended juvenile phase via numerous moults, leading to adulthood (Anger $\mathrm{et}$ al. 2015; Clark \& Cuesta 2015: table 1). Callichimaera perplexa shows some of the features of a young juvenile crab: it has a normal, partially folded pleon with a simple telson, no tail fan, functional pereiopods 2 and 3, male gonopods G1 and G2, and female pleopods 2-5.

The larval and postlarval growth pattern is poorly known in podotreme crabs (Rice 1980). Postlarval stages are known in Raninoides benedicti, that, after four planktonic zoeae and one megalopa (with pleopods on somites 2-5 and uropods on somite 6, see Knight 1968: figs 13, 14, 64 a, b, 65), was reared through seventh and eighth crab stages. Unfortunately, the complete morphology, in particular that of the pleon, is not described. Only the shape of the carapace and chelipeds of the first five crabs are figured (Knight 1968: figs 15-16). The morphology of the megalopa of $R$. benedicti is conform to those of rare known raninid megalopae: an unidentified west-African raninid (found in the stomach of a tuna fish) with extended pleon (Monod 1965: figs 1-20); Notopus dorsipes (Linnaeus, 1758), with partlially flexed pleon (Studer 1883: fig. 7a-d); Ranilia ?constricta (Kidd \& Rice 1986: fig. 2).

The complete larval development of the 'red frog crab' Ranina ranina (Linnaeus, 1758) is more informative in that its first instar juvenile crab is well described and figured (except for the thoracic sternum) (Minagawa 1990: 587, figs 1-10): in the megalopa, the pleon bears setose pleopods on somites 2-5 and uropods on somite 6, while in the first juvenile instar the uropods are 'atrophied' and marginal setae have 'disappeared' although setae are represented on somites preceding the rounded teslon (compare Minagawa 1990: fig. 9M, N, vs fig. $10 \mathrm{~L}, \mathrm{~N})$. These characteristics partially correspond to those enumerated by Luque et al. (2019: 7, 8, fig. 3D, G -I) to eliminate the hypothesis that Callichimaera perplexa could be a megalopa: no uropods on each side of pleonal somite 6; presence of a clear sexual dimorphism, with sexually dimorphic pleon, sclerotized G1 and G2, and female pleopods on pleonal somites 2 to 5 ; more typically spanner-like chelae. In addition, the range of body sizes (cl 6.6 to $15.1 \mathrm{~mm}$; cw 3.8 to $9.6 \mathrm{~mm}$ ) "are consistent with several growth instars" instead of the unique megalopal stage.

In Lyreidus tridentatus de Haan, 1841 (Lyreididae Guinot, 1977), the megalopa (after about six zoeal stages) shows the same essential traits as those of Ranina ranina, i.e. almost square telson with setose uniramous uropods, no sexual dimorphism, and pereiopods without specialised articles (Williamson 1965: figs 4-7); unfortunately, the postlarval instars are unknown.

The chimaeric crab of Luque et al. (2019) looks like a megalopa by its elongate body and huge eyes, but the pleon is partially flexed instead of being completely extended. In addition, which is most important, the sexes are recognisable. The carapace bears distinct grooves and ridges, whereas the brachyuran megalopa is generally not grooved.

To which brachyuran group could the Callichimaeridae belong? My first hypothesis is that it could be assigned to the Gymnopleura Bourne, 1922 (Bourne 1922), a podotreme representative that includes the Raninoidea De Haan, 1839 and the exclusively fossil Palaeocorystoidea Lörenthey in Lőrenthey \& Beurlen (1929), to which corresponds the "Raninoida Ahyong \& others, 2007" (i.e. Ahyong et al. 2007) in the Treatise Online (Schweitzer et al. 2018a). For the nomenclatural status of Gymnopleura, see Guinot et al. (2013: 871, tables 1, 5, 6) and Jagt et al. (2015: table 1). However, the reduced P4 and P5 of C. perplexa could invalidate this hypothesis (only P5 may be reduced in gymnopleures) and would be in favour of a crab belonging to the Cyclodorippiformia.

The extremely diverse shapes of the thoracic sternum of Gymnopleura show evidence of their complex evolutionary history. Even in Recent raninoids, the sternal somites are difficult to interpret: in particular, sternites 4 and 5 are not separated by a suture comparable to that of other podotremes. Furthermore, the delimitation of sternites is complicated by the existence of sternal extensions between the pereiopods, which modify the outline. Lateral outgrowths of the sternites joining the thoracic sternum to the carapace are inserted at various levels: for example in Raninoidinae Lőrenthey in Lőrenthey \& Beurlen (1929), there is a wide extension between P1-P2, even wider between P2-P3, morever with pointed projections or lobes, so that their arthrodial cavities are encircled by sclerites (see Guinot 1993b: fig. 5). We do not know if, and to what extent, such extensions exist in postlarval juvenile crabs of gymnopleures and, in particular, in the case of fossils. The oversized width of the sternite 5 of Callichimaera perplexa could be explained by the fact that it includes sternal extensions. For example Quasilaeviranina ovalis (Rathbun, 1935) shows a wide thoracic sternum in which the sternal outgrowths are well visible laterally (Tucker 1998: fig. 19). Fossil Raninoides H. Milne Edwards, 1837 show wide thoracic sternites (Van Bakel et al. 2012b: fig. 44C, D).

The larval development and the postlarval growth of cyclodorippoids are largely unknown or incompletely documented (see Wear \& Batham 1975; Rice 1981, 1988; Hartnoll 2015).

In conclusion, if Callichimaera perplexa is a Brachyura:

- it could be a postlarval juvenile crab;

- Callichimaeridae could belong to a podotreme family, gymnopleure or cyclodorippoid; 
- the taxonomic status of Callichimaeroidea is uncertain: the small P4 and the filiform P5, the paddle-like P2-P3, the pediform mxp3 are criteria to be taken into consideration. "Callichimaera defies all of these 'crabby' features and forces a re-think of our definition of what makes a crab a crab." (Luque, YaleNews, Meet Callichimaera perplexa, the platypus of crabs, April 24, 2019): I partially agree, but I cannot consider it is a "decarcinised crab", i.e. having lost crab-like characters (sensu Scholtz 2014);

- the section Callichimaeroida may well be unfounded, Callichimaera being probably a podotreme belonging to the archaeobrachyuran section Gymnopleura, in a superfamily to be determined.

\section{Acknowledgements}

I wish to thank Àlex Ossó (Tarragona, Catalonia) for kindly providing photographs of several fossil crabs from his private collection, Pedro Artal (Museo Geológico del Seminario de Barcelona, Barcelona, Spain) for photographs of Viaia robusta, Laure Corbari (curator of Crustacea, MNHN, Paris) for the photograph of Homolodromia aff. kai, Joseph Poupin (École navale, BCRM Brest, France) for the photographs of two extant dromiids and two extant majoids, Paula Rodríguez Moreno (Direction générale déléguée des collections, MNHN, Paris) for the photographs of Hyas coarctatus, and Francisco J. Vega (Instituto de Geología, Universidad Nacional Autónoma de México, Mexico) for a new photograph of Archaeochiapasa mardoqueoi. I am also grateful to Natalia Starzyck (Institute of Systematics and Evolution of Animals, Polish Academy of Sciences, Kraków, Poland) for permission to publish some of her original sketches. I am very grateful to Michal Krobicki (Polish Geological Institute, National Research Institute, Kraków, Poland) who kindly scanned for me several original photographs published by Wehner (1988) and authorized me to use them to illustrate this article and who, in agreement with the publisher of the Polish Geological Society, allowed me to reproduce some carapace reconstitutions published by Wehner (1988). The KARUBENTHOS 2 Expedition, led by Laure Corbari and Philippe Bouchet, has yielded very rare Majoidea, such as Esopus crassus, revealing unknown features and unusual shapes, which makes our understanding of the biodiversity of this very large group easier. Thanks are also due to Pierre-Olivier Méthot (Faculté de philosophie de l'Université Laval, Québec, Canada) for English translation of the texts by Gaston Bachelard, Marie Hennion (e-ReColNat, ANR11-INBS-0004) for her help with the photographs, and to Emmanuel Côtez, desk editor of Geodiversitas, for his professional and kind assistance with illustrations. And lastly, I wish extend my deep gratitude to Denis Audo (Yunnan Key Laboratory for Palaeobiology, Yunnan University, China) and Alessandro Garassino (Museo di Storia Naturale, Milano, Italy) for their constructive and helfpul reviews, and, more particularly, to John Jagt (Natuurhistorisch Museum Maastricht, Maastricht, the Netherlands) for his complete revision of the manuscript and for his encouragement.

\section{REFERENCES}

Abele L. G. \& Felgenhauer B. E. 1982. — Crustacea: Malacostraca: Decapoda, in PARKER S. P. (ed.), Synopsis and Classification of Living Organisms. McGraw-Hill Book Company, New-York: 296-326.

Ahyong S. T., Lai J. C. Y., Sharkey D., Colgan D. J. \& NG P. K. L. 2007. - Phylogenetics of the brachyuran crabs (Crustacea: Decapoda): the status of Podotremata based on small subunit nuclear ribosomal RNA. Molecular Phylogenetics and Evolution 45 (2): 576-586. https://doi.org/10.1016/j.ympev.2007.03.022

Alcock A. 1900. - Materials for a Carcinological Fauna of India. $\mathrm{N}^{\circ}$ 5. The Brachyura Primigenia or Dromiacea. Journal of the Asiatic Society of Bengal 68 (Part II. - Natural Science. N III. - 1899) 1900: 123-169. https://biodiversitylibrary.org/page/35558166

Anger K., Queiroga H. \& Calado R. 2015. - Larval development and behaviour strategies in Brachyura, in CASTRO P., DAVIE P. J. F., Guinot D., Schram F. R. \& Vaupel Klein J. C. (eds), Decapoda: Brachyura, Treatise on Zoology - Anatomy, Taxonomy, Biology. Vol. 9C-1. Crustacea. Brill, Leiden and Boston: 318-374. https://doi.org/10.1163/9789004190832_008

Armstrong A., Nyborg T., Bishop G. A., Ossó-Morales À. \& VEGA F. J. 2009. - Decapod crustaceans from the Paleocene of Central Texas, USA. Revista Mexicana de Ciencias Geológicas 26 (3): 745-763.

Artal P., Guinot D., Van Bakel B. \& Castillo J. 2008. — Ibericancridae, a new dakoticancroid family (Decapoda, Brachyura, Podotremata) from the upper Campanian (Upper Cretaceous) of Spain. Zootaxa 1907: 1-27. https://doi.org/10.11646/zootaxa.1907.1.1

Artal P., Van Bakel B. W. M., Fraaije R. H. B., Jagt J. W. M. \& KlompMaker A. A. 2012. - New Albian-Cenomanian crabs (Crustacea, Decapoda, Podotremata) from Monte Orobe, Navarra, northern Spain. Revista Mexicana de Ciencias Geológicas 29: 398-410.

Artal P., Van Bakel B. W. M. \& OnetTi A. 2014. - A new inachid crab (Brachyura, Majoidea) from the Middle Eocene of the provinces of Barcelona and Girona (Catalonia, Spain), in FraAiJe R. H. B., HyŽnÝ M., JagT J. W. M., Krobicki M. \& Van BaKel B. W. M. (eds), Proceedings of the $5^{\text {th }}$ Symposium on Mesozoic and Cenozoic Decapod Crustaceans, Krakow, Poland, 2013: a tribute to Pál Mihály Müller. Scripta Geologica 147: 153-161. http://dpc.uba.uva.nl/16/nr147/a13

BACHELARD G. 1938. - La formation de l'esprit scientifique. Contribution à une psychanalyse de la connaissance objective. Vrin, Paris, 257 p. (translation by Mary McAllester-Jones, 2002, Clinamen Press)

Balss H. 1957. — Decapoda. VIII. Systematik, in BRONN H. G. (ed.), Klassen und Ordnungen des Tierreichs. Fünfter Band, 1. Abteilung, 7. Buch, 12. Lieferung. Akademische Verlagsgesellschaft, Geest \& Portig K.-G., Leipzig: 1505-1672.

BeCKer C. \& SCHOLTZ G. 2017. - Phylogenetic implications of sperm storage in Podotremata: histology and 3D-reconstructions of spermathecae and gonopores in female carrier crabs (Decapoda: Brachyura: Homoloidea). Journal of Morphology 278 (1): 89-105. https://doi.org/10.1002/jmor.20621

BELL T. 1858. - A monograph of the fossil malacostracous Crustacea of Great Britain. Part I. Crustacea of the London Clay. Monograph of the Palaeontographical Society London 10 (40) [1856]: i-viii + 1-44, pls 1-11. https://biodiversitylibrary.org/page/36971881

Beschin C., Busulini A., De Angeli A. \& Tessier G. 1994. Crostacei eocenici della "Cava Boschetto" di Nogarole Vicentino (Vicenza - Italia settentrionale). Lavori Società Veneziana di Scienze Naturali 19: 159-215.

Beschin C., De Angeli A., Checchi A. \& Zarantonello G. 2012. - Crostacei del giacimento Eocenico di Grola presso Spagnago di Cornedo Vicentino (Vicenza, Italia settentrionale) (Decapoda, Stomatopoda, Isopoda). Museo di Archeologia e Scienze Naturali "G. Zannato", Montecchio Maggiore (Vicenza), 98 p. 
Beurlen K. 1928. — Die fossilen Dromiaceen und ihre Stammesgeschichte. Paläontologische Zeitschrift 10: 144-183. https://doi. org/10.1007/BF03041570

Bishop G. A. 1976. - Ekalakia lamberti n. gen., n. sp. (Crustacea, Decapoda) from the Upper Cretaceous Pierre Shale of Eastern Montana. Journal of Paleontology 50: 398-401. https://www. jstor.org/stable/1303520

BisHOP G. A. 1986. - Taphonomy of the North American decapods. Journal of Crustacean Biology 6: 326-355. https://doi. org/10.2307/1548174

BisHOP G. A. 1987. — Dromiopsis kimberlyae, a new Late Cretaceous crab from the Pierre Shale of South Dakota. Proceedings of the Biological Society of Washington 100: 35-39. https://biodiversitylibrary.org/page/34570435

Blow W. C. \& MANNING R. B. 1996. - Preliminary descriptions of 25 new decapod crustaceans from the Middle Eocene of the Carolinas, U.S.A. Tulane Studies in Geology and Paleontology 29 (1): 1-26.

BorRadAILE L. A., 1907. - On the classification of the Decapod Crustaceans. Annals and Magazine of Natural History, series 7 , 19: 457-486. https://biodiversitylibrary.org/page/24254917

BOURNE G. C. 1922. - The Raninidae: a study in carcinology. Journal of the Linnean Society, Zoology 35 (231): 25-79. https:// doi.org/10.1111/j.1096-3642.1922.tb01495.x

Bouvier E.-L. 1896. - Sur l'origine homarienne des Crabes: étude comparative des Dromiacés vivants et fossiles. Bulletin de la Société philomathique, gème série, 8 (2): 34-110. https://biodiversitylibrary.org/page/31967457

BOWMAN T. E. \& ABELE A. G. 1982. - Classification of the Recent Crustacea, in ABELE L. G. (ed.) The Biology of Crustacea. Vol. 1, Systematics, the Fossil Records, and Biogeography. Academic Press, New York: 1-27.

Breton G. 2009. - Description of Priscinachus elongatus n. gen., n. sp., and Priscinachidae n. fam. for the earliest spider crab (Crustacea, Decapoda, Majoidea), from the French Cretaceous (Cenomanian). Geodiversitas 31: 509-523. https://doi. org/10.5252/g2009n3a2

Carmona-SuÁreZ C. \& Poupin J. 2016. — Majoidea crabs from Guadeloupe Island, with a documented list of species for the Lesser Antilles (Crustacea, Decapoda, Brachyura, Majoidea). Zoosystema 38 (3): 353-387. https://doi.org/10.5252/z2016n3a5

CHACE F. A. 1940. - Reports on the scientific results of the Atlantis expeditions to the West Indies, under the joint auspices of University of Havana and Harvard University. The Brachyuran crabs. Torreia 4: 1-65.

Charbonnier S., Audo D., Garassino A. \& HyŽNÝ M. 2017. Fossil Crustacea of Lebanon. Muséum national d'Histoire naturelle, Paris, 252 p. (Mémoires du Muséum national d'Histoire naturelle; 210).

Checchia-Rispoli G. 1917. - "Distefania", nuovo genere di Brachiuri del Cenomaniano della Sicilia. Bollettino della Società Zoologica Italiana 3 (3) [for 1914]: 173-186. https://biodiversitylibrary.org/page/34033893

Chen J., Xing Y., YaO W., Xu X., Zhang C., Zhang Z. \& LiU Q. 2019. - Phylomitogenomics reconfirm the phylogenetic position of the genus Metaplax inferred from the two grapsid crabs (Decapoda: Brachyura: Grapsoidea). PLoS ONE 14 (1): e0210763. https://doi.org/10.1371/journal.pone.0210763

Chu K. H. C., Schubart C. D., Shih H.-T. \& Tsang L. M. 2015. Genetic diversity and evolution of Brachyura (Chapter 71-13), in Castro P., Davie P. J. F., Guinot D., Schram F. R. \& voN Vaupel KleIN J. C. (eds), Decapoda: Brachyura, Treatise on Zoology - Anatomy, Taxonomy, Biology. Vol. 9C-2, Crustacea. Brill, Leiden/ Boston: 775-820. https://doi.org/10.1163/9789004190832_016

ClarK P. F. 2009. - The Bearing of Larval Morphology on Brachyuran Phylogeny, in Martin J. W., Crandall K. A. \& Felder D. L. (eds), Decapod Crustacean Phylogenetics. Crustacean Issues 18: 221-241. https://doi.org/10.1201/9781420092592
CLARK P. F. \& CUESTA J. A. 2015. — Larval systematics of Brachyura, in Castro P., Davie P. J. F., Guinot D., Schram F. R. \& VON Vaupel Klein J. C. (eds), Decapoda: Brachyura, Treatise on Zoology - Anatomy, Taxonomy, Biology. Vol. 9C-2, Crustacea. Brill, Leiden/ Boston: 981-1048. https://doi.org/10.1163/9789004190832_020 Clark P. F. \& Webber W. R. 1991. - A redescription of Macrocheira kaempferi (Temminck, 1836) zoeas with a discussion of the classification of the Majoidea Samouelle, 1819 (Crustacea, Brachyura). Journal of Natural History 25: 1259-1279. https:// doi.org/10.1080/00222939100770781

Colavite J., Windsor A. \& Santana W. 2019. — Three new species and a new genus of majoid crabs from the eastern Pacific (Decapoda, Brachyura). ZooKeys 825: 1-24. https://doi.org/10.3897/ zookeys.825.32271

Collins J. S. H. 1997. — Fossil Homolidae (Crustacea; Decapoda). Bulletin of the Mizunami Fossil Museum 24: 51-71.

Collins J. S. H. \& Wierzbowski A. 1985. - Crabs from the Oxfordian sponge megafacies of Poland. Acta Geologica Polonica 35 (1-2): 73-88.

Collins J. S. H., Ross A. J., Genzano G. \& Manzian H. 2006. Earleria gen. nov. \& Gabriella gen. nov., replacement names for Foersteria Arai \& Brinkmann-Voss, 1980 (Cnidaria, Hydrozoa, Mitrocomidae) and Foersteria Wehner, 1988 (Crustacea, Decapoda, Prosopidae), junior homonyms of Foersteria Szépligeti, 1896 (Insecta, Hymenoptera, Braconidae). Bulletin of the Mizunami Fossil Museum 33: 125-126.

Crandall K. A., Porter M. L. \& Pérez-Losada M. 2009. Crabs, shrimps, and lobsters (Decapoda), in Hedges S. B. \& Kumar S. (eds), The Timetree of Life. Oxford University Press, Oxford: 293-297.

CraWford R. S. 2008. - A new species of fossil homolid crab (Decapoda: Brachyura) from the Río Foyel Formation (Paleogene), Río Negro Province, Argentina. Journal of Paleontology 82 (4): 835-841. https://doi.org/10.1666/06-111.1

CRÔNIER C. \& Boursicot P.-Y. 2009. - A new decapod crustacean faunule from the Middle Jurassic of north-west France. Palaeontology 52: 1275-1289. https://doi.org/10.1111/j.14754983.2009.00896.x

Davie P. J. F., Guinot D. \& NG P. K. L. 2015a. — Anatomy and functional morphology of Brachyura, in CASTRO P., DAVIE P. J. F., Guinot D., Schram F. R. \& VON VAupel Klein J. C. (eds), Decapoda: Brachyura, Treatise on Zoology - Anatomy, Taxonomy, Biology. Vol. 9C-1, Crustacea. Brill, Leiden/Boston: 11-163. https://doi.org/10.1163/9789004190832_004

Davie P. J. F., GUINOT D. \& NG P. K. L. 2015b. — Phylogeny of Brachyura, in Castro P., Davie P. J. F., Guinot D., Schram F. R. \& VON VAUPEL KLEIN J. C. (eds), Decapoda: Brachyura, Treatise on Zoology - Anatomy, Taxonomy, Biology. Vol. 9C-2, Crustacea. Brill, Leiden and Boston: 921-979. https://doi. org/10.1163/9789004190832_019

De Grave S., Pentcheff N. D., Ahyong S. T., Chan T. Y., CranDAll K. A., DworschaK P. C., Felder D. L., Feldmann R. M., Fransen C. H. J. M., Goulding L. Y. D., Lemaitre R., Low M. E. Y., Martin J. W., NG P. K. L., SChWeitzer C. E., Tan S. H., TSHUdy D. \& WeTZER R. 2009. - A classification of living and fossil genera of decapod crustaceans. Raffles Bulletin of Zoology Supplement 21: 1-109. http://hdl.handle.net/10088/8358

De HaAn W. 1833-1850. - Crustacea, in Von Siebold P. F. (ed.), Fauna Japonica sive Descriptio animalium, quae in itinere per Japoniam, jussu et auspiciis superiorum, qui summum in India batava Imperium tenent, suscepto, annis 1823-1830 collegit, notis, observationibus et adumbrationibus illustravit. Lugduni Batavorum (= Leiden), fasc. 1-8, 243 p. (1833), fasc. 1, Praemissa: ix, x; Expositio: xi-xvi; 1839 , fasc. $4: 73-108$; 1841 , fasc. 5: 109164; 1849, fasc. 7: i-xxxii; 1850, fasc. 8: vii-xvii. https://doi. org/10.5962/bhl.title.124951

DuBOIS A. 2005. - Proposed Rules for the incorporation of nomina of higher-ranked zoological taxa in the International Code of Zoo- 
logical Nomenclature. 1. Some general questions, concepts and terms of biological nomenclature. Zoosystema 27 (2): 365-426.

Dubois A. 2006a. - Proposed Rules for the incorporation of nomina of higher-ranked zoological taxa in the International Code of Zoological Nomenclature. 2. The proposed Rules and their rationale. Zoosystema 28 (1): 165-258.

Dubois A. 2006b. - Incorporation of nomina of higher-ranked taxa into the International Code of Zoological Nomenclature: some basic questions. Zootaxa 1337: 1-37. https://doi.org/10.11646/ zootaxa.1337.1.1

Dubois A. 2007. - Phylogeny, taxonomy and nomenclature: the problem of taxonomic categories and of nomenclatural ranks. Zootaxa 1519: 27-68. https://doi.org/10.11646/zootaxa.1519.1.3

DuBOIS A. 2010. - Zoological nomenclature in the century of extinctions: priority vs. usage. Organisms Diversity \& Evolution 10: 259-274. https://doi.org/10.1007/s13127-010-0021-3

DuboIs A. 2012. - The distinction between introduction of a new nomen and subsequent use of a previously introduced nomen in zoological nomenclature. Bionomina 5: 57-80. https://doi. org/10.11646/bionomina.5.1.2

DubOIS A. \& Bour R. 2010. - The distinction between familyseries and class-series nomina in zoological nomenclature, with emphasis on the nomina created by Batsch $(1788,1789)$ and on the higher nomenclature of turtles. Bonn Zoological Bulletin 57 (2): 149-171. https://biodiversitylibrary.org/page/44823265

Felder D. L., Martin J. W. \& \& Goy J. W. 1985. - Patterns of Early Post-Larval Development of Decapods, in WenNER A. M. (ed.), Larval Growth. Crustacean Issues 2: 163-225. https://doi. org/10.1201/9781315140698

Feldmann R. M. \& KeYES I. W. 1992. - Systematic and stratigraphic review with catalogue and locality index of the Mesozoic and Cenozoic decapod Crustacea of New Zealand. New Zealand Geological Survey Record 45: 1-73.

FELDMANN R. M. \& SCHWEITZER C. E. 2004. — Decapod crustaceans from the lower Miocene of northwestern Venezuela (Cerro La Cruz, Castillo Formation). Special Papers in Palaeontology 71 (71): 7-22.

Feldmann R. M. \& SCHWeitZer C. E. 2009. - Revision of Jurassic Homoloidea De Haan, 1839, from the Ernstbrunn and Stramberk limestones, Austria and the Czech Republic. Annalen des Naturhistorischen Museums in Wien series A 111: 183-206.

Feldmann R. M. \& SchWeitzer C. E. 2010. - Is Eocarcinus Withers, 1932, a basal brachyuran? Journal of Crustacean Biology 30: 241-250. https://doi.org/10.1651/09-3230.1

FELDMANN R. M. \& SCHWeITZER C. E. 2019. - Earliest known sponge crab (Brachyura, Dromiidae) from the Upper Cretaceous Wenonah Formation, New Jersey, USA. Bulletin of the Mizunami Fossil Museum 45: 1-6.

FELDMANn R. M. \& Tshudy D. M. 1989. - Evolutionary patterns in macrurous decapod crustaceans from Cretaceous to early Cenozoic rocks of the James Ross Island region, Antarctica, in Crame J. A. (ed.), Origins and Evolution of the Antarctic Biota. Geological Society, Special Publication 47: 183-195. https://doi. org/10.1144/GSL.SP.1989.047.01.14

Feldmann R. M. \& Wilson M. T. 1988. - Eocene decapod crustaceans from Antarctica. Geological Society of America Memoir 169: 465-488.

Feldmann R. M., LazĂR I. \& SChweitzer C. E. 2006. - New crabs (Decapoda: Brachyura: Prosopidae) from Jurassic (Oxfordian) sponge bioherms of Dobrogea, Romania. Bulletin of the Mizunami Fossil Museum 33: 1-20.

Feldmann R. M., Schweitzer C. E. \& Wahl W. R. 2008. Ekalakia (Decapoda: Brachyura): the preservation of eyes links Cretaceous crabs to Jurassic ancestors. Journal of Paleontology 82 (5): 1030-1034. https://doi.org/10.1666/08-006.1

Feldmann R. M., Tshudy D. M. \& Thomson M. R. A. 1993. Late Cretaceous and Paleocene Decapod crustaceans from James Ross Basin, Antarctic Peninsula. The Paleontological Society Memoir 28: i-iv, 1-41. https://www.jstor.org/stable/1315582
Feldmann R. M., Bice K. L., Schweitzer Hopkins C., Salva E. W. \& PiCKFORD K. 1998. - Decapod Crustaceans from the Eocene Castle Hayne Formation, North Carolina: paleoceanographic Implications. Journal of Paleontology 72 (1): 1-28. https:// doi.org/10.1017/S0022336000059916

Feldmann R. M., Schweitzer C. E., Bennett O., Franțescu O. D., Resar N. \& TRUdeau A. 2011. - New Eocene Brachyura (Crustacea: Decapoda) from Egypt. Neues Jahrbuch für Geologie und Paläontologie, Abhandlungen 262: 323-353. https://doi. org/10.1127/0077-7749/2011/0202

Feldmann R. M., Schweitzer C. E., Baltzly L. M., Bennett O. A., Jones A. R., Mathias F. F., Weaver K. L. \& Yost S. L. 2013. - New and previously known decapod crustaceans from the Late Cretaceous of New Jersey and Delaware, USA. Bulletin of the Mizunami Fossil Museum 39: 7-37.

FERRATGES F. A. 2017. — Los crustáceos fósiles de las cuencas Surpirenaicas. Asociación Cultural Bajo Jalón, Zaragoza, 100 p. (Cuadernos de Paleontología Aragonesa; 8).

FÖRSTER R. 1985. - Frühe Anomuren und Brachyuren (Decapoda, Crustacea) aus dem mittleren Dogger. Mitteilungen aus der Bayerischen Staatssammlung für Paläontologie und historische Geologie 25: 45-60. https://biodiversitylibrary.org/page/30453068

FÖRSTER R. 1986. - Der erste Nachweis eines brachyuren Krebses aus dem Lias (oberes Pliensbach) Mitteleuropas. Mitteilungen aus Bayerischen Staatssammlung für Paläontologie und historische Geologie 26: 25-31. https://biodiversitylibrary.org/page/28587353

FÖRSTER R., GAZDZICKI A. \& WRONA R. 1985. — First record of a homolodromiid crab from Lower Miocene glaciomarine sequence of West Antarctica. Neues Jahrbuch für Geologie und Paläontologie 6: 340-348.

FraAiJe R. H. B. 1996a. - Evolution of Reef-Associated Decapod Crustaceans through Time, with Particular Reference to the Maastrichtian Type Area. Unpublished doctoral thesis, Utrecht University.

FraAije R. H. B. 1996b. - Late Cretaceous swimming crabs: radiation, migration, competition, and extinction. Acta Geologica Polonica 46: 269-278.

Fraaije R. H. B., Van Bakel B. W. M., Guinot D. \& Jagt J. W. M. 2013. - A new Middle Jurassic (Bajocian) homolodromioid crab from northwest France; the earliest record of the Tanidromitidae. Boletín de la Sociedad Geológica Mexicana 65 (2): 249-254. https://doi.org/10.18268/BSGM2013v65n2a6

Fraaije R. H. B., Van Bakel B. W. M., Jagt J. W. M. \& Vega P. A. 2018. - The rise of a novel, plankton-based marine ecosystem during the Mesozoic: a bottom-up model to explain new higher-tier invertebrate morphotypes. Boletín de la Sociedad Geológica Mexicana 70 (1): 187-200. https://doi.org/10.18268/ BSGM2018v70n1a11

Fraaije R. H. B., Van Bakel B. W. M., Jagt J. W. M., CharbonNIER S. \& PEZY J. P. 2019. - The oldest record of galatheoid anomurans (Decapoda, Crustacea) from Normandy, northwest France. Neues Jahrbuch für Geologie und Paläontologie, Abhandlungen 292 (3): 291-297. https://doi.org/10.1127/njgpa/2019/0821

FRANTESCU O. D. 2011. - Brachyuran decapods (including five new species and one new genus) from Jurassic (OxfordianKimmeridgian) coral reef limestones from Dobrogea, Romania. Neues Jahrbuch für Geologie und Paläontologie, Abhandlungen 259: 271-297. https://doi.org/10.1127/0077-7749/2010/0110

FrANŢESCU O. 2014. - Fossil decapods from the Cretaceous (late Albian) of Tarrant County, Texas. Neues Jahrbuchfür Geologie und Paläontologie, Abhandlungen 273 (3): 221-239. https://doi. org/10.1127/0077-7749/2014/0427

Franțescu O., Feldmann R. M. \& Schweitzer C. E. 2010. A new genus and species of dromiid crab (Decapoda, Brachyura) from the middle Eocene of South Carolina, in FrANSEN C. H. J. M., De Grave S. \& NG P. K. L. (eds), Studies on Malacostraca: Lipke Bijdeley Holthuis Memorial Volume. Brill, Leyde: 255-267 (Crustaceana Monographs; 14). https://doi. org/10.1163/9789047427759_007 
GARASSINO A. 2009. - The thoracic sternum and spermatheca in the extant genera of the family Homolidae De Haan, 1839 (Crustacea Decapoda Brachyura). Memorie della Società italiana di Scienze naturali e del Museo civico di Storia naturale di Milano 36 (3): 1-80.

Garassino A., De Angeli A \& Pasini G. 2008. — New decapod assemblage from the Upper Cretaceous (Cenomanian-Turonian) of Gara Sbaa, southeastern Morocco. Atti della Società Italiana de Scienze naturali e del Museo civico di Storia naturale di Milano 149: 37-67.

GARASSINO A., DE ANGELI A. \& SCHWEIGERT G. 2005. — Brachyurans from the Upper Jurassic Kimmeridgian-Tithonian lithographic limestones of Pfalzpaint and Breitenhill (Bavaria, S Germany). Atti della Società Italiana de Scienze naturali e del Museo civico di Storia naturale di Milano 146: 69-78.

GARTH J. S. 1958. - Brachyura of the Pacific coast of America, Oxyrhyncha. Allan Hancock Pacific Expeditions 21 (1): xxii + 1-499 (https://biodiversitylibrary.org/page/4681630); (2), 501854, pls A-Z4, 1-55.

GlaESSNER M. F. 1929. - Crustacea Decapoda, in POMPECKJ F. J. (ed.), Fossilium Catalogus, 1: Animalia. Vol. 41. W. Junk, Berlin, 464 p.

Glaessner M. F. 1933. — Die Krabben der Juraformation. Zentralblatt für Mineralogie, Geologie und Paläontologie B 3: 178-191.

Glaessner M. F. 1969. — Decapoda, in Moore R. C. (ed.), Treatise on Invertebrate Paleontology. Part R, Arthropoda, 4. Vol. 2. The Geological Society of America \& The University of Kansas Press, Boulder, Colorado/Lawrence, Kansas: R400-R533, R626-R628.

Gordon I. 1950. - Crustacea Dromiacea. Part I: Systematic account of the Dromiacea collected by the "John Murray" Expedition. Part II. The morphology of the spermatheca in certain Dromiacea. The John Murray Expedition 1933-34, Scientific Reports 9 (3): 201-253.

GORODISKI A. \& ReMY J.-M. 1959. - Sur les decapodes éocènes du Sénégal occidental. Bulletin de la Société géologique de France, 7e série 1 (3): 315-319.

Gould S. J. 1977. - Ontogeny and Phylogeny. Harvard University Press, Cambridge, Massachusetts, $501 \mathrm{p}$.

GuINOT D. 1977. - Proposition pour une nouvelle classification des Crustacés Décapodes Brachyoures. Comptes Rendus hebdomadaires des Séances de l'Académie des Sciences, série D, Sciences naturelles 285 (10): 1049-1052.

GuinOT D. 1978. —Principes d'une classification évolutive des Crustacés Décapodes Brachyoures. Bulletin biologique de la France et de la Belgique, nouvelle série, 112 (3): 211-292.

Guinot D. 1979. - Données nouvelles sur la morphologie, la phylogenèse et la taxonomie des Crustacés Décapodes Brachyoures. Muséum national d'Histoire naturelle, Paris, 354 p. (Mémoires du Muséum national d'Histoire naturelle, Sér. A - Zoologie). https://biodiversitylibrary.org/page/57902073

Guinot D. 1991. — Établissement de la famille des Poupiniidae pour Poupinia hirsuta nov. sp. de Polynésie (Crustacea Decapoda Brachyura: Homoloidea). Bulletin du Muséum national d'Histoire naturelle naturelle Paris (4) 12 [for 1990] A (3/4): 577-605. https://biodiversitylibrary.org/page/58936221

GUINOT D. 1993a. - Données nouvelles sur les crabes primitifs (Crustacea Decapoda Brachyura). Comptes rendus de l'Académie des Sciences, série 3, 316 (2): 1225-1232. https://gallica.bnf.fr/ ark:/12148/bpt6k5754198c/f501.item

GuinOT D. 1993b. - Données nouvelles sur les Raninoidea de Haan, 1841 (Crustacea Decapoda Brachyura Podotremata). Comptes rendus de l'Académie des Sciences, série 3, 316 (2): 1324 1331. https://gallica.bnf.fr/ark:/12148/bpt6k5754198c/f594.item

GuinOT D. 1995. - Crustacea Decapoda Brachyura: Révision des Homolodromiidae Alcock, 1900, in CrosNiER A. (ed.), Résultats des Campagnes MUSORSTOM. Vol. 13. Muséum national d'Histoire naturelle, Paris: 155-282 (Mémoires du Muséum national d'Histoire naturelle ; 163). https://biodiversitylibrary. org/page/58815048
GUINOT D. 2008. - A re-evaluation of the Dynomenidae (Decapoda, Brachyura, Podotremata), with the recognition of four subfamilies. Zootaxa 1850: 1-26. https://doi.org/10.11646/zootaxa.1850.1.1

GUINOT D. 2012. - Remarks on Inachoididae Dana, 1851, with the description of a new genus and the resurrection of Stenorhynchinae Dana, 1851, and recognition of the inachid subfamily Podochelinae Neumann, 1878 (Crustacea, Decapoda, Brachyura, Majoidea). Zootaxa 3416: 22-40. https://doi.org/10.11646/ zootaxa.3416.1.2

Guinot D. \& QuenetTe G. 2005. - The spermatheca in podotreme crabs (Crustacea, Decapoda, Brachyura, Podotremata) and its phylogenetic implications. Zoosystema 2 (2): 267-342.

Guinot D. \& Richer DE Forges B. 1995. - Crustacea, Decapoda, Brachyura : révision de la famille des Homolidae de Haan, 1841 , in Crosnier A. (ed.), Résultats des Campagnes MUSORSTOM. Vol. 13. Muséum national d'Histoire naturelle, Paris: 283-517 (Mémoires du Muséum national d'Histoire naturelle ; 163). https://biodiversitylibrary.org/page/58815176

GUINOT D. \& TAVARES M. 2001. - Une nouvelle famille de crabes du Crétacé, et la notion de Podotremata Guinot, 1977 (Crustacea, Decapoda, Brachyura). Zoosystema 23 (3): 507-546.

Guinot D. \& TAVARES M. 2003. - A new subfamilial arrangement for the Dromiidae de Haan, 1833, with diagnoses and description of new genera and species (Crustacea, Decapoda Brachyura). Zoosystema 25 (1): 43-129.

Guinot D. \& WiCKSTEN M. K. 2015. - Phylogeny of Brachyura, in Castro P., Davie P. J. F., Guinot D., Schram F. R. \& Von Vaupel Klein J. C. (eds), Decapoda: Brachyura, Treatise on ZoologyAnatomy, Taxonomy, Biology. Vol. 9C-2. Crustacea. Brill, Leiden/ Boston: 583-638. https://doi.org/10.1163/9789004190832_019

GUINOT D., TAVARES M. \& CASTRO P. 2013. - Significance of the sexual openings and supplementary structures on the phylogeny of brachyuran crabs (Crustacea, Decapoda, Brachyura), with new nomina for higher-ranked podotreme taxa. Zootaxa 3665 1-414. https://doi.org/10.11646/zootaxa.3665.1.1

Guinot D., Vega F. J. \& VAN BAKel B. W. M. 2008. - Cenomanocarcinidae n. fam., a new Cretaceous podotreme family (Crustacea, Decapoda, Brachyura, Raninoidia), with comments on related families. Geodiversitas 30 (4): 681-719.

Guinot D., Carbot-Chanona G. \& Vega F. J. 2019. - Archaeochiapasidae n. fam., a new early Cenomanian brachyuran family from Chiapas, Mexico, new insights on Lecythocaridae Schweitzer \& Feldmann, 2009, and phylogenetic implications (Crustacea, Decapoda, Brachyura, Eubrachyura). Geodiversitas 41 (7): 285-322. https://doi.org/10.5252/geodiversitas2019v41a7

HARTNOLl R. G. 2015. - Postlarval life histories of Brachyura, in Castro P., Davie P. J. F., Guinot D., Schram F. R. \& VON VAuPEL KleIn J. C. (eds), Decapoda: Brachyura, Treatise on ZoologyAnatomy, Taxonomy, Biology. Vol. 9C-1. Crustacea. Brill, Leiden and Boston: 375-416. https://doi.org/10.1163/9789004190832_009

HaUg J. T. \& HAUG C. 2014. - Eoprosopon klugi (Brachyura) the oldest unequivocal and most "primitive" crab reconsidered. Palaeodiversity 7: 149-158.

Haug J. T., MarTin J. W. \& Haug C. 2015. — A 150-million-yearold crab larva and its implications for the early rise of brachyuran crabs. Nature Communications 6: 6417. https://doi.org/10.1038/ ncomms7417 https://doi.org/10.1038/ncomms7417

HENDERSON R. 1888. - Report on the Anomura collected by $\mathrm{H}$. M. S. Challenger during the years 1873-1876. Report of the Scientific Results of the Voyage of H.M.S. Challenger during the Years 1873-76, Zoology. Vol. 27 (1): i-xi, 1-221, pls 1-21. https:// biodiversitylibrary.org/page/2007946

HeNNIG W. 1966. - Phylogenetics Systematics. University of Illinois Press, Urbana, 263 p.

Holthuis L. B. 1962. - Dromia Weber, 1795 (Crustacea, Decapoda): proposed designation of a type-species under the plenary powers. Z. N. (S.) 1488. Bulletin of Zoological Nomenclature 19 (1): 51-57. https://biodiversitylibrary.org/page/12220912 
Hultgren K. M., Guerao G., Marques F. P. L. \& Palero F. P. 2009. - Assessing the contribution of molecular and larval morphological characters in a combined phylogenetic analysis of the superfamily Majoidea, in MarTin J. W., CRANDAll K. A. \& Felder D. L. (eds), Decapod Crustacean Phylogenetics. Crustacean Issues 18: 437-455. https://doi.org/10.1201/9781420092592

HYŽNÝ M. \& ZORN I. 2016. - A catalogue of the type and figured fossil decapod crustaceans in the collections of the Geological Survey of Austria in Vienna. Jahrbuch der Geologischen Bundesanstalt 156 (1-4): 127-177.

HYŽNÝ M., SCHLÖGL J. \& KROBICKI M. 2011. — Tanidromites insignis (von Meyer, 1857) (Crustacea: Decapoda: Brachyura) from Late Jurassic non-biohermal facies of the Western Tethys (Pieniny Klippen Belt, Western Carpathians, Slovakia). Neues Jahrbuch für Geologie und Paläontologie, Abhandlungen 262 (2): 213-226. https://doi.org/10.1127/0077-7749/2011/0193

HyŽNÝ M., StarzyK N., Robins C. M. \& KoČova Veselská M. 2015. - Taxonomy and palaeoecology of a decapod crustacean assemblage from the Oxfordian of Stránska skála (Southern Moravia, Czech Republic). Bulletin of Geosciences 90 (3): 633650. https://doi.org/10.3140/bull.geosci.1559

ICZN 1964. - Opinion 688. Dromia Weber, 1795 (Crustacea, Decapoda). Designation of a type-species under the plenary powers. Bulletin of Zoological Nomenclature 21 (1): 16-19.

ICZN 1999. - International Code of Zoological Nomenclature. Fourth edition. International Trust for Zoological Nomenclature, London: i-xxix, 1-306.

ImAIZUMi R. 1952. - A Miocene crab, Hyas tsuchidai n. sp., from the Wakkanai Formation of Teshio Province, Hokkaido. Transactions and Proceedings of the Palaeontological Society of Japan, new series, 1952 (6): 179-183. https://doi.org/10.14825/ prpsj1951.1952.6_179

JaGT J. W. M., VAN BAKEL B. W. M. \& FraAije R. H. B. 2007. Palaeodromites crypticus, a new early-middle Cenomanian dynomenid crab (Crustacea, Decapoda) from southern Belgium. Bulletin de l'Institut royal des Sciences naturelles de Belgique, Sciences de la Terre 77: 77-82.

Jagt J. W. M., Fraaije R. H. B. \& Van Bakel B. W. M. 2014a. Decapod crustacean 'odds and ends' from the Maastrichtian type area (southeast Netherlands, northeast Belgium), in FrAAIJE R. H. B., HYŽNÝ M., JAGT J. W. M., KROBICKI M. \& VAN BAKEI B. W. M. (eds), Proceedings of the $5^{\text {th }}$ Symposium on Mesozoic and Cenozoic Decapod Crustaceans, Krakow [sic], Poland, 2013: A tribute to Pál Mihály Müller. Scripta Geologica 147: 95-115. http://dpc.uba.uva.nl/16/nr147/a09

Jagt J. W. M., Van Bakel B. W. M., Fraaije R. H. \& Neumann C. 2014b. - New data on mid-Cretaceous dromioid crabs (Crustacea, Decapoda, Brachyura) from northwest Germany and southwest Iran, in FraAiJe R. H. B., HYŽNÝ M., JAGT J. W. M., Krobicki M. \& VAn BaKel B. W. M. (eds), Proceedings of the $5^{\text {th }}$ Symposium on Mesozoic and Cenozoic Decapod Crustaceans, Krakow [sic], Poland, 2013: A tribute to Pál Mihály Müller. Scripta Geologica 147: 35-47. http://dpc.uba.uva.nl/16/nr147/a06

Jagt J. W. M., Van Bakel B. W. M., Guinot D., Fraaije R. H. B. \& ARTAl P. 2015. - Fossil Brachyura, in Castro P., DaVIE P. J. F., Guinot D., Schram F. R. \& Von Vaupel Klein J. C. (eds), Treatise on Zoology - Anatomy, Taxonomy, Biology. Vol. 9C-2. The Crustacea. Leiden/Boston, Brill: 847-920. https:// doi.org/10.1163/9789004190832 018

KarasaWa H. \& Hirota T. 2019. - Two new species of Planoprosopon (Decapoda: Brachyura: Longodromitidae) from the Torinosu Group (Upper Jurassic-Lower Cretaceous), Shikoku, Japan. Bulletin of the Mizunami Fossil Museum 45: 27-32, 1 appendix.

Karasawa H., Schweitzer C. E. \& Feldmann R. M. 2011. Phylogenetic analysis and revised classification of podotrematous Brachyura (Decapoda) including extinct and extant families. Journal of Crustacean Biology 31: 523-565. https://doi.org/10.1651/103423.1
Karasawa H., Kato H. \& Terabe K. 2006. — A new member of the Family Prosopidae (Crustacea: Decapoda: Brachyura) from the Early Cretaceous (Barremian) of Japan. Revista Mexicana de Ciencias Geológicas 23 (3): 344-349.

Kato H., TAKahashi T. \& Taira M. 2010. — Late Jurassic decapod crustaceans from northeast Japan. Palaeontology 53 (4): 761-770. https://doi.org/10.1111/j.1475-4983.2010.00960.x

Kato H., NAKASHIMA R. \& YANAGISAWA Y. 2014. - Two new Early Pliocene species of the crab genus Hyas Leach, 1814 (Majoidea, Oregoniidae) from northeast Japan, in FrAAIJE R. H. B., HYŽNÝ M., Jagt, J. W. M., Krobicki M. \& Van Bakel B. W. M. (eds), Proceedings of the $5^{\text {th }}$ Symposium on Mesozoic and Cenozoic Decapod Crustaceans, Krakow, Poland, 2013: A tribute to Pál Mihály Müller. Scripta Geologica 147:269-287. http://dpc.uba.uva.nl/16/nr147/a20

KLOMPMAKER A. A. 2013. - Extreme diversity of decapod crustaceans from the mid-Cretaceous (late Albian) of Spain: implications for Cretaceous decapod paleoecology. Cretaceous Research 41: 150-185. https://doi.org/10.1016/j.cretres.2012.12.003

Klompmaker A. A., Artal P. \& Gulisano G. 2011a. - The Cretaceous crab Rathbunopon: revision, a new species and new localities. Neues Jahrbuch für Geologie und Paläontologie Abhandlungen 260: 191-202. https://doi.org/10.1127/0077-7749/2011/0170

Klompmaker A. A., Artal P., Fraaije R. H. B. \& Jagt J. W. M. 2011b. - Revision of the family Gastrodoridae (Crustacea, Decapoda), with description of the first species from the Cretaceous. Journal of Paleontology 85 (2): 226-233. https://doi. org/10.1666/10-028.1

Klompmaker A. A., Feldmann R. M. \& Schweitzer C. E. 2012.A hotspot for Cretaceous Goniodromitids (Decapoda: Brachyura) from reef associated strata in Spain. Journal of Crustacean Biology 32 (5): 780-801. https://doi.org/10.1163/193724012X635340

Klompmaker A. A., Chistoserdov A. Y. \& Felder D. L. 2016. Possible shell disease in 100 million-year-old crabs. Diseases of Aquatic Organisms 119: 91-99. https://doi.org/10.3354/dao02988

Klompmaker A. A., Ortiz J. D. \& Wells N. A. 2013a. - How to explain a decapod crustacean diversity hotspot in a mid-Cretaceous coral reef. Palaeogeography, Palaeoclimatology, Palaeoecology 374: 256-273. https://doi.org/10.1016/j.palaeo.2013.01.024

Klompmaker A. A., Karasawa H., Portell R. W., Fraaije R. H. B. \& ANDO Y. 2013b. - An overview of predation evidence found on fossil decapod crustaceans with new examples of drill holes attributed to gastropods and octopods. Palaios 28 (9): 599 613. https://doi.org/10.2110/palo.2013.p13-026r

Klompmaker A. A., Schweitzer C. E., Feldmann R. M. \& KOWALEWSKI M. 2013c. - The influence of reefs on the rise of Mesozoic marine crustaceans. Geology 41 (11): 1179-1182. https://doi.org/10.1130/G34768.1

Klompmaker A. A., Schweitzer C. E., Feldmann R. M. \& KOWALEWSKI M. 2015. - Environmental and scale-dependent evolutionary trends in the body size of crustaceans. Proceedings of the Royal Society B 282: 20150440. https://doi.org/10.1098/ rspb.2015.0440

Klompmaker A. A., Robins C. M., Portell R. W. \& De Angeli A. (unpublished). - Crustaceans as hosts of parasites throughout the Phanerozoic. https://doi.org/10.1101/505495

KidD R. J. \& Rice A. L. 1986. - A mechanism for the transport of swarms of raninid megalopas in the Eastern Caribbean. Journal of Crustacean Biology 6 (4): 679-685. https://doi. org/10.2307/1548381

KNiGHT M. D. 1968. - The larval development of Raninoides benedicti Rathbun (Brachyura, Raninidae), with notes on the Pacific records of Raninoides laevis (Latreille). Crustaceana, Supplement, No. 2 (Studies on Decapod Larval Development): 145-169. https://www.jstor.org/stable/25027393

KROBICKI M. \& ZATOŃ M. 2008. — Middle and Late Jurassic roots of brachyuran crabs: palaeoenvironmental distribution during their early evolution. Palaeogeography, Palaeoclimatology, Palaeoecology 263: 30-43. https://doi.org/10.1016/j.palaeo.2008.01.025 
Krobicki M. \& ZATOŃ M. 2016. — A new homolodromioid crab (Brachyura: Dromiacea: Tanidromitidae) from the Bajocian of Central Poland and a review of the known Middle Jurassic homolodromioids. Journal of Crustacean Biology 36: 695-715. https://doi.org/10.1163/1937240X-00002463

KrZemińska E., StarzyK N., Fraaije R. H. B. \& SchWeigert G. 2019. - Augenrest morphology in Bucculentum Wehner (Decapoda: Brachyura). Volume of Abstracts, 7th Symposium on Mesozoic and Cenozoic Decapod Crustaceans, 17-21 June, 2019, Ljubljana (Slovenia): 25-26.

Landman N. H., Dommergues J. L. \& Marchand D. 1991. The complex nature of progenetic species - examples from Mesozoic ammonites. Lethaia 24: 409-421. https://doi. org/10.1111/j.1502-3931.1991.tb01495.x

Landman N. H., Fraaije R. H. B., Klofak S. M., Larson N. L., Bishop G. A. \& KRUTA I. 2014. - Inquilinism of a baculite by a dynomenid crab from the Upper Cretaceous of South Dakota. American Museum Novitates 3818: 1-16. https://doi. org/10.1206/3818.1

LARGHI C. 2002. - Mithracia oppionii sp. nov. (Crustacea, Decapoda, Brachyura) from the Eocene of Chiampo (Vicenza, Italy). Bulletin of the Mizunami Fossil Museum 29: 61-68.

LARGHI C. 2004. - Brachyuran decapod Crustacea from the Upper Cretaceous of Lebanon. Journal of Paleontology 78 (3): 528541. https://doi.org/10.1666/0022-3360(2004)078<0528:BDCFTU $>2.0 . \mathrm{CO} ; 2$

LÖRENTHEY E. \& BEURLEN K. 1929. - Die fossilen Decapoden der Länder der Ungarischen Krone. Geologica Hungarica (Palaeontologica) 3: 1-421, 16 pl., 12 tables.

LUQUE J. 2015a. - A puzzling frog crab (Crustacea: Decapoda: Brachyura) from the Early Cretaceous Santana Group of Brazil: frog first or crab first? Journal of Systematic Palaeontology 13 (2): 153-166. https://doi.org/10.1080/14772019.2013.871586

LUQUE J. 2015b. - The oldest higher true crabs (Crustacea: Decapoda: Brachyura): insights from the Early Cretaceous of the Americas. Palaeontology 58 (2): 251-263. https://doi.org/10.1111/pala.12135

Luque J., Karasawa H., Kerr K. A., Duque A. \& Jaramillo C. 2012. - Evolution of Primitive Crabs: Insights from the Neotropics. Volume of Abstracts, Geological Society of America's 124th Annual Meeting \& Exhibition, Nov. 4-7, 2012. Charlotte, North Carolina, United States.

Luque J., Feldmann R. M., Vernygora O., Schweitzer C. E., Cameron C. B., Kerr K. A., Vega F. J., Duque A., Strange M., Palmer A. R. \& Jaramillo C. 2019. - Exceptional preservation of mid-Cretaceous marine arthropods and the evolution of novel forms via heterochrony. Supplementary Materials. Science Advances 5 (4): eaav3875. https://doi.org/10.1126/sciadv.aav3875

LuQue J., Allison W. T., Bracken-Grissom H. D., Jenkins K. M., Palmer A.R., Porter M. L. \& Wolfe J. M. (unpublished). Evolution of crab eye structures and the utility of ommatidia morphology in resolving phylogeny. Preprint first posted online Oct. 7, 2019. https://doi.org/10.1101/786087

MA K. Y., Qin J., Lin C.-W., CHAN T.-Y., NG P. K. L., CHU K. H. \& TSANG L. M. 2019. - Phylogenomic analyses of brachyuran crabs support early divergence of primary freshwater crabs. Molecular Phylogenetics and Evolution 135: 62-66. https://doi. org/10.1016/j.ympev.2019.02.001

Marco-Herrero A., Torres P., Cuesta J. A., Guerao G., PALERO F. \& ABELLÓ P. 2013. - The systematic position of Ergasticus (Decapoda, Brachyura) and allied genera, a molecular and morphological approach. Zoologica Scripta 42 (4): 427-439. https://doi.org/10.1111/zsc.12012

MARQues F. \& Pohle G. 1998. - The use of structural reduction in phylogenetic reconstruction of decapods and a phylogenetic hypothesis for fifteen genera of Majidae: testing previous hypotheses and assumptions. Invertebrate Reproduction and Development 33 (2-3): 241-262. https://doi.org/10.1080/07 924259.1998 .9652636
Marques F. \& Pohle G. 2003. - Searching for larval support for majoid families (Crustacea: Brachyura) with particular reference to Inachoididae Dana, 1851. Invertebrate Reproduction and Development 43: 71-82. https://doi.org/10.1080/0792425 9.2003 .9652523

MARTIN J. W. 1990. — Crabs of the family Homolodromiidae. II. Dicranodromia felderi, new species, from the western Atlantic, with notes on the type series of D. ovata A. Milne Edwards, 1880. Journal of Crustacean Biology 10 (4): 708-720. https://doi. org $/ 10.2307 / 1548415$

MCKinney M. L. \& MCNamara K. J. 1991. - Heterochrony: the Evolution of Ontogeny. Plenum, New York: i-xix, 1-437. https:// doi.org/10.1007/978-1-4757-0773-1

MCLAY C. L. 1993. - Crustacea Decapoda, the sponge crabs (Dromiidae) of New Caledonia and the Philippines with a review of the genera, in Crosnier A. (ed.), Résultats des campagnes MUSORSTOM, Volume 10. Muséum national d'Histoire naturelle, Paris: 111-251 (Mémoires du Muséum national d'Histoire naturelle; 156).

MCLAY C. L. 1999. - Crustacea Decapoda: Revision of the Family Dynomenidae, in Crosnier A. (ed.), Résultats des Campagnes MUSORSTOM, Volume 20. Muséum national d'Histoire naturelle, Paris: 427-569 (Mémoires du Muséum national d'Histoire naturelle ; 180).

MCLAY C. L. 2001. - A new genus and two new species of unusual dromiid crabs (Brachyura: Dromiidae) from Northern Australia. Records of the Australian Museum 53: 1-8. https://doi.org/10.385 3/j.0067-1975.53.2001.1319

M'Coy F. 1849. - On the classification of some British fossil Crustacea with notices of new forms in the University collection at Cambridge. Annals and Magazine of Natural History, Series 2, 4: 161-179. https://biodiversitylibrary.org/page/18686685

MEYER H. vON 1858. - Briefliche Mitteilungen. Neues Jahrbuch für Mineralogie, Geologie, Geognosie, und Petrefaktenkunde 1858: 59-62.

MeYer H. VON 1860. - Die Prosoponiden oder die Familie der Maskenkrebse. Palaeontographica 7: 183-222, pl. 23. https:// biodiversitylibrary.org/page/35370069

Milne-EDWARDS A. 1873-1880. — Études sur les Xiphosures et les Crustacés de la Région mexicaine, in Mission Scientifique au Mexique et dans l'Amérique centrale. Recherches zoologiques pour servir à l'histoire de la faune de l'Amérique centrale et du Mexique, Cinquième partie. Tome premier. Imprimerie nationale, Paris, 368 p., 61 pls. https://biodiversitylibrary.org/page/51060544

Milne-EDWARDS A. \& Bouvier E.-L. 1902. - Reports on the results of dredging, under the supervision of Alexander Agassiz, in the Gulf of Mexico (1877-78), in the Caribbean Sea (187879), and along the Atlantic coast of the United States (1880), by the U. S. Coast Survey Steamer "Blake”. XXXIX. Les Dromiacés et Oxystomes. Memoirs of the Museum of Comparative Zoology at Harvard College 27 (1): 1-127. https://biodiversitylibrary.org/ page/4311917

MiLNE EDWARDS H. 1837. - Histoire naturelle des Crustacés comprenant l'Anatomie, la Physiologie et la Classification de ces Animaux. Librairie Encyclopédique de Roret, Paris. Vol. 2: 1-531 p. https:// doi.org/10.5962/bhl.title.16170

MinAGAWA M. 1990. - Complete larval development of the red frog crab Ranina ranina (Crustacea, Decapoda, Raninidae) reared in the laboratory. Nippon Suisan Gakkaishi 56 (4): 577-589. https:// doi.org/10.2331/suisan. 56.577

MoERICKE W. 1889. - Die Crustaceen der Stramberger Schichten. Palaeontologische Mitteilungen aus dem Museum des Koeniglich Bayerischen Staates 3: 43-72.

MoeriCKe W. 1897. — Die Crustaceen der Stramberger Schichten. Palaeontographica, Supplement II (6): 43-72 (https://biodiversitylibrary.org/page/48106225), pl. 6 (https://biodiversitylibrary. org/page/56369616).

MONOD T. 1965. - Sur une mégalope de raninide [Crust. Brachyura]. Bulletin de l'Institut français d'Afrique noire, séries $A, 27$ (4): 1237-1244. 
Müller P. M., Krobicki M. \& Wehner G. 2000. — Jurassic and Cretaceous primitive crabs of the family Prosopidae (Decapoda: Brachyura) - Their taxonomy, ecology and biogeography. Annales Societatis Geologorum Poloniae 70: 49-79.

NG P. K. L. 2016. - The taxonomy of Speodromia platyarthrodes (Stebbing, 1905) (Crustacea: Brachyura), an unusual dromiid crab endemic to South Africa. Zootaxa 4111 (3): 261-275. https:// doi.org/10.11646/zootaxa.4111.3.4

NG P. K. L., Guinot D. \& Davie P. J. F. 2008. — Systema Brachyurorum: Part 1. An annotated checklist of extant brachyuran crabs of the world. Raffles Bulletin of Zoology, Supplement 17: 1-286.

NG P. K. L, RAVINESH R. \& RAVICHANDRAN S. 2017. — A new large oregoniid spider crab of the genus Pleistacantha Miers, 1879, from the Bay of Bengal, India (Crustacea, Brachyura, Majoidea). ZooKeys 716: 127-146. https://doi.org/10.3897/zookeys.716.21349

Nyborg T., Garassino A., Vega F.J. \& KovalchuK G. 2019. Fossil decapod crustaceans from the Early Cretaceous of Oregon, USA. Neues Jahrbuch für Geologie und Paläontologie, Abhandlungen 293 (2): 127-138. https://doi.org/10.1127/njgpa/2019/0836

Ossó A., Castany J., Gombau E. \& Forner E. 2015. — Primera cita de Mithracites vectensis Gould, 1859 (Decapoda: Brachyura: Homoloidea) a la península Ibèrica. Nemus 5: 85-91. http://hdl. handle.net/10234/158873

Ossó A., Van Bakel B., Ferratges-Kwekel F. A. \& MorenoBeDmar J. A. 2018. - A new decapod crustacean assemblage from the lower Aptian of La Cova del Vidre (Baix Ebre, province of Tarragona, Catalonia). Cretaceous Research 92: 94-107. https:// doi.org/10.1016/j.cretres.2018.07.011

Patrulius D. 1959. - Contributions à la systématique des décapodes néojurassiques. Revue de Géologie et Géographie 3 (2): 249-257.

Patrulius D. 1966. - Les Décapodes du Tithonique inférieur de Woźniki (Carpathes Polonaises Occidentales). Annales de la Société géologique de Pologne 36 (4): 495-517, pls 30, 31.

PLOTNICK R. E. 1986. - Taphonomy of a modern shrimp: implications for the arthropod fossil record. Palaios 1: 286-293. https:// doi.org/10.2307/3514691

Plotnick R. E., Baumiller T. \& Wetmore K. L. 1988. — Fossilization potential of the mud crab, Panopeus (Brachyura: Xanthidae) and temporal variability in crustacean taphonomy. Palaeogeography, Palaeoclimatology, Palaeoecology 63: 27-44. https://doi. org/10.1016/0031-0182(88)90089-2

PoHLE G. 1991. - Larval development of Canadian Atlantic oregoniid crabs (Brachyura: Majidae), with emphasis on Hyas coarctatus alutaceus (Brandt, 1851), and a comparison with Atlantic and Pacific conspecifics. Canadian Journal of Zoology 69 (11): 2717-2737. https://doi.org/10.1139/z91-384

Pohle G. \& Marques M. 2000. - Larval stages of Paradasygyius depressus (Bell, 1835) (Crustacea: Decapoda: Brachyura: Majidae) and a phylogenetic analysis for 21 genera of Majidae. Proceedings of the Biological Society of Washington 113 (3): 739-760. https:// biodiversitylibrary.org/page/35517216

Porter M. L., Pérez-Losada M. \& Crandall K. A. 2005. Model-based multi-locus estimation of decapod phylogeny and divergence times. Molecular Phylogenetics and Evolution 37: 355369. https://doi.org/10.1016/j.ympev.2005.06.021

PoupIN J. 2018. — Les Crustacés décapodes des Petites Antilles: avec de nouvelles observations pour Saint-Martin, la Guadeloupe et la Martinique. Muséum national d'Histoire naturelle, Paris, 264 p. (Patrimoines naturels ; 77).

POUPIN J. \& CORBARI L. 2016. - A preliminary assessment of the deep-sea Decapoda collected during the KARUBENTHOS 2015 Expedition to Guadeloupe Island. Zootaxa 4190 (1): 1-107. https://doi.org/10.11646/zootaxa.4190.1.1

Quenstedt F. A. 1856-1858. - Der Jura. H. Laup, Tübingen: 842 p., $100 \mathrm{pls}$

QuenstedT F. A. 1867. - Handbuch der Petrefaktenkunde. 2nd edition. H. Laupp, Tübingen: 982 p., atlas with 86 pls. https:// doi.org/10.5962/bhl.title.30642
Rathbun M. J. 1893. - Catalogue of the crabs of the family Maiidæ in the U. S. National Museum. Proceedings of the United States National Museum 16 (927): 63-103, pls 1-6. https://doi. org/10.5479/si.00963801.16-927.63

Rathbun M. J. 1925. - The spider crabs of America. Bulletin of the United States National Museum 129: i-xx + 1-613, 283 pls. https://biodiversitylibrary.org/page/7846075

Rathbun M. J. 1937. - The oxystomatous and allied crabs of America. Bulletin of the United States National Museum 166: i-vi, 1-278, pls 1-86. https://biodiversitylibrary.org/page/7690752

Reindl A., Strobach T., Becker C., Scholtz G. \& Schubert T. 2015. - Crab or lobster? Mental principles underlying the categorization of crustaceans by biology experts and non-experts. Zoologischer Anzeiger 256: 28-35. https://doi.org/10.1016/j. jcz.2015.03.001

Reindl A., Schubert T., Strobach T., Becker C. \& Scholtz G. 2018. - Adaptation aftereffects in the perception of crabs and lobsters as examples of complex natural objects. Frontiers in Psychology 9: (1905). https://doi.org/10.3389/fpsyg.2018.01905

RiCE A. L. 1980. - Crab zoeal morphology and its bearing on the classification of the Brachyura. Transactions of the Zoological Society of London 35: 271-424. https://doi.org/10.1111/j.1096-3642.1980. tb00060.x

RiCE A. L. 1981. - Crab zoeae and brachyuran classification: a re-appraisal. Bulletin of the British Museum of Natural History, Zoology 40 (5): 287-296. https://biodiversitylibrary.org/page/2357372

RICE A. L. 1983. - Zoeal evidence for brachyuran phylogeny, in SCHRAM F. R. (ed.), Crustacean Phylogeny. Crustacean Issues 1: 313-329.

RiCE A. L. 1988. - The megalopa stage in majid crabs, with a review of spider crab relationships based on larval characters, in FinCham A. A. \& RainBow P. S. (eds), Aspects of Decapod Crustacean Biology. Proceedings of a Symposium, Zoological Society of London. Clarendon Press, Oxford: 27-46.

Robin N., Van Bakel B. W. M., D'Hondt J.-L. \& Charbonnier S. 2015. - A new early brachyuran (Crustacea, Decapoda) from the Middle Jurassic of northwest France, epibionts and ecological considerations. Contributions to Zoology 84 (3): 179-191. https:// doi.org/10.1163/18759866-08403001

Robin N., VAn BaKel B. W. M., PaCaud J.-M. \& Charbonnier S. 2017. - Decapod crustaceans from the Paleocene (Danian) of the Paris Basin (Vigny stratotype and allied localities) and a limpet palaeoassociation. Journal of Systematic Palaeontology 15 (4): 257-273. https://doi.org/10.1080/14772019.2016.1182950

SANTANA W. R. A. 2008. — Revisão taxonômica e relaçôes filogenéticas em Inachoididae Dana, 1851 (Crustacea, Brachyura, Majoidea). $\mathrm{PhD}$ thesis, Instituto de Biociências, Universidad de São Paulo, São Paulo. https://doi.org/10.11606/T.41.2008.tde-29012009-100852

SCHÄFER W. 1951. — Fossilisations-Bedingungen brachyurer Krebse. Abhandlungen der Senckenbergischen Naturforschenden Gesellschaft 485: 221-238.

SCHOLTZ G. 2014. - Evolution of crabs-history and deconstruction of a prime example of convergence. Contributions to Zoology 83: 87-105. https://doi.org/10.1163/18759866-08302001

Schram F. R. 1986. - Crustacea. Oxford University Press, 606 p.

SCHWEIGERT G. 2006. - A specimen of Prosopon hebes v. Meyer, 1840 (Decapoda: Brachyura: Prosoponidae) from the Middle Jurassic of SW Germany. Neues Jahrbuch fur Geologie und Paläontologie Monatshefte 2006 (6):361-370. https://doi.org/10.1127/ njgpm/2006/2006/361

SCHWEIGERT G. 2011. - The decapod crustaceans of the Upper Jurassic Solnhofen limestones: a historical review and some recent discoveries. Neues Jahrbuch für Geologie und Paläontologie, Abhandlungen 260: 131-140. https://doi.org/10.1127/00777749/2011/0162

SCHWEIGERT G. 2019. - An additional representative of Lecythocaridae (Decapoda: Brachyura: Dromiacea) from the Upper Jurassic of southern Germany. Journal of Crustacean Biology 39 (1): 36-39. https://doi.org/10.1093/jcbiol/ruy092 
SCHWeigert G. \& Koppka J. 2011. - Decapods (Crustacea: Brachyura) from the Jurassic of Germany and Lithuania, with descriptions of new species of Planoprosopon and Tanidromites. Neues Jahrbuch für Geologie und Paläontologie, Abhandlungen 260: 221-235. https://doi.org/10.1127/0077-7749/2011/0136

SCHWEIGERT G. \& Robins C. M. 2016. — Earliest representatives of Lecythocaridae (Crustacea: Brachyura) from the Upper Jurassic of southern Germany. Neues Jahrbuch für Geologie und Paläontologie Abhandlungen 280 (3): 325-330. https://doi.org/10.1127/ njgpa/2016/0583

Schweitzer C. E. \& Feldmann R. M. 2005. - Decapod crustaceans, the K/P event, and Palaeocene recovery, in KoEneman S. \& JeNNER R. A. (eds), Crustacea and Arthropod Relationships. Crustacean Issues 16: 17-53. https://doi.org/10.1201/9781420037548

SChWeitzer C. E. \& Feldmann R. M. 2008a. - A new classification for some Jurassic Brachyura (Crustacea: Decapoda: Brachyura: Homolodromioidea): families Goniodromitidae Beurlen, 1932 and Tanidromitidae new family. Senckenbergiana Lethaea 87: 119-156. https://doi.org/10.1007/BF03043911

Schweitzer C. E. \& Feldmann R. M. 2008b. - Revision of the genus Laeviprosopon Glaessner, 1933 (Decapoda: Brachyura: Homolodromioidea: Prosopidae) including two new species. Neues Jahrbuch für Geologie und Paläontologie, Abhandlungen 250 (3): 273-285. https://doi.org/10.1127/0077-7749/2008/0250-0273

Schweitzer C. E. \& Feldmann R. M. 2009a. - Revision of the Prosopinae sensu Glaessner, 1969 (Crustacea: Decapoda: Brachyura) including four new families, four new genera, and five new species. Annalen des Naturhistorischen Museums in Wien series $A$ 110: $55-121$.

SChweitzer C. E. \& Feldmann R. M. 2009b. - New species of Longodromitidae Schweitzer \& Feldmann, 2009, from the Ernstbrunn Formation, Late Jurassic (Tithonian), Austria. Annalen des Naturhistorischen Museums in Wien series A 111: 207-224.

SCHWeItZer C. E. \& Feldmann R. M. 2009c. - Revision of Gabriella Collins et al., 2006 (Decapoda: Brachyura: Homolodromioidea: Tanidromitidae) with new Jurassic species. Neues Jahrbuch für Geologie und Paläontologie, Abhandlungen 252: 1-16. https://doi.org/10.1127/0077-7749/2009/0252-0001

SChweitzer C. E. \& Feldmann R. M. 2009d. - Revision of the genus Cyclothyreus Remeš, 1895 (Decapoda: Brachyura: Dromioidea). Neues Jahrbuch für Geologie und Paläontologie, Abhandlungen 253 (2-3): 357-372.

SChWeitzer C. E. \& Feldmann R. M. 2010a. - The oldest Brachyura (Decapoda: Homolodromioidea: Glaessneropsoidea) known to date (Jurassic). Journal of Crustacean Biology 30: 251256. https://doi.org/10.1651/09-3231.1

SCHWeitzer C. E. \& Feldmann R. M. 2010b. - A new family of Mesozoic Brachyura (Glaessneropsoidea) and reevaluation of Distefania Checchia-Rispoli, 1917 (Homolodromioidea: Goniodromitidae). Neues Jahrbuch für Geologie und Paläontologie, Abhandlungen 256 (3): 363-380. https://doi.org/10.1127/0077-7749/2010/0059

Schweitzer C. E. \& Feldmann R. M. 2010c. - Revision of Cycloprosopon and additions to Eodromites (Brachyura: Homolodromioidea: Goniodromitidae). Annalen des Naturhistorischen Museums in Wien series A 112: 169-194.

SCHWeitzer C. E. \& FeldMann R. M. 2010d. - Sphaerodromiidae (Brachyura: Dromiacea: Dromioidea) in the fossil record. Journal ofCrustacean Biology 30 (3): 417-429. https://doi.org/10.1651/093260.1

Schweitzer C. E. \& Feldmann R. M. 2010e. - The genus Coelopus Étallon, 1861 (Brachyura: Glaessneropsoidea: Longodromitidae) with new species. Neues Jahrbuch für Geologie und Paläontologie, Abhandlungen 258: 51-60. https://doi.org/10.1127/0077$7749 / 2010 / 0084$

Schweitzer C. E. \& Feldmann R. M. 2010f. - New fossil decapod crustaceans from the Remy Collection, Muséum national d'Histoire naturelle, Paris. Geodiversitas 32 (3): 399-415. https:// doi.org/10.5252/g2010n3a3
Schweitzer C. E. \& Feldmann R. M. 2011. - Revision of some fossil podotrematous Brachyura (Homolodromiidae; Longodromitidae; Torynommidae). Neues Jahrbuch für Geologie und Paläontologie, Abhandlungen 260: 237-256. https://doi. org/10.1127/0077-7749/2011/0138

Schweitzer C. E. \& Feldmann R. M. 2012a. - Revision of some fossil podotrematous Brachyura (Homolodromiidae; Longodromitidae; Torynommidae) Neues Jahrbuch für Geologie und Paläontologie, Abhandlungen 260: 237-256. https://doi. org/10.1127/0077-7749/2011/0138

SCHWEITZER C. E. \& FeldMANN R. M. 2012b. — Reappraisal of a Paleocene crab (Brachyura: Dromiacea) from Texas. Journal of Crustacean Biology 32 (4): 591-595. https://doi.org/10.1163/193724012x634170

SCHWEITZER C. E. \& FELDMANN R. M. 2015. - Faunal turnover and niche stability in marine Decapoda in the Phanerozoic. Journal of Crustacean Biology 35 (5): 633-649. https://doi. org/10.1163/1937240X-00002359

Schweitzer C. E., Feldmann R. M., Gonzáles-Barba G. \& VeGA F. J. 2002. - New crabs from the Eocene and Oligocene of Baja California Sur, Mexico and an assessment oe the evolutionary and paleobiogeographic implications of Mexican fossil decapods. Journal of Paleontology 76 Supplement 59: 1-43. https:// doi.org/10.1666/0022-3360(2002)76[1:NCFTEA]2.0.CO;2

Schweitzer C. E., Nyborg T. G., Feldmann R. M. \& Ross R. L. M. 2004. - Homolidae De Haan, 1839 and Homolodromiidae Alcock, 1900 (Crustacea: Decapoda: Brachyura) from the Pacific Northwest of North America and a reassessment of their fossil records. Journal of Paleontology 78: 133-149. https://doi.org/10.1666/0022-3360(2004)078<0133:HDHA $\mathrm{HA}>2.0 . \mathrm{CO} ; 2$

Schweitzer C. E., Feldmann R. M. \& LazĂr I. 2007. — Decapods from Jurassic (Oxfordian) sponge megafacies of Dobrogea, Romania and reconsideration of Nodoprosopon Beurlen, 1928. Neues Jahrbuchfür Geologie und Paläontologie, Abhandlungen 244: 99-113. https://doi.org/10.1127/0077-7749/2007/0244-0099

Schweitzer C. E., Feldmann R. M. \& LaZĂR I. 2009. — Fossil Crustacea (excluding Cirripedia and Ostracoda) in the University of Bucharest Collections, Romania, including two new species. Bulletin of the Mizunami Fossil Museum 35: 1-14.

Schweitzer C. E., Feldmann R. M., Garassino A., Karasawa H. \& SCHWEIGERT G. 2010. - Systematic list of fossil decapod crustacean species. Crustaceana Monographs 10: 1-230. https:// doi.org/10.1163/193724012x626575

Schweitzer C. E., Feldmann R. M. \& Karasawa H. 2012a. Part R, Revised, Volume 1, Chapter 8M: Systematic descriptions: Infraorder Brachyura, Section Dromiacea. Treatise Online 51: 1-43, 24 figs. https://doi.org/10.17161/to.v0i0.4336

SchWeitzer C. E., Feldmann R. M. \& Karasawa H. 2012b. Part R, Revised, Volume 1, Chapter 8N: Systematic descriptions: Infraorder Brachyura, Section Homolida. Treatise Online 52: 1-12, 6 figs. https://doi.org/10.17161/to.v0i0.4337

Schweitzer C. E., Feldmann R. M. \& KarasaWa H. 2017a. Part R, Revised, Volume 1, Chapter 8O: Systematic descriptions: Infraorder Brachyura, Section Torynommoida. Treatise Online 94: 1-2, 1 fig. https://doi.org/10.17161/to.v0i0.6656

Schweitzer C. E., Feldmann R. M. \& Karasawa H. 2017b. Part R, Revised, Volume 1, Chapter 8S: Systematic descriptions: Infraorder Brachyura, Section Cyclodorippoida. Treatise Online 97: 1-6, figs 1-4. https://doi.org/10.17161/to.v0i0.6659

Schweitzer C. E., Feldmann R. M., Karasawa H., Franțescu O. D. \& KlOMPMAKER A. A. 2017c. - Part R, Revised, Volume 1, Chapter 8P, Systematic descriptions: Infraorder Brachyura, Section Etyoida. Treatise Online 95: 1-9, figs 1-3. https://doi. org/10.17161/to.v0i0.6657

Schweitzer C. E., Feldmann R. M., Karasawa H. \& Luque J. 2018a. - Part R, Revised, Volume 1, Chapter 8S: Systematic descriptions: Infraorder Brachyura, Section Raninoida. Treatise Online 113: 1-42, 4 figs 1-20. 
SchWeitzer C. E., Feldmann R. M., LazĂR I., SChWeigert G. \& FRANȚESCU O. D. 2018b. - Decapoda (Anomura; Brachyura) from the Late Jurassic of the Carpathians, Romania. Neues Jahrbuch für Geologie und Paläontologie, Abhandlungen 288 (3): 307-341. https://doi.org/10.1127/njgpa/2018/0744

SchweItZer C. E., Feldmann R. M., Phillips G. E. \& Armstrong A. 2019. - Cretaceous Decapoda (Crustacea) from Mississsipi, USA. Neues Jahrbuch für Geologie und Paläontologie, Abhandlungen 293 (2): 145-197. https://doi.org/10.1127/njgpa/2019/0838

Schweitzer Hopkins C., Salva E. W. \& Feldmann R. M. 1999. Re-evaluation of the genus Xanthosia Bell, 1863 (Decapoda: Brachyura: Xanthidae) and descriptions of two new species from the Cretaceous of Texas. Journal of Paleontology 73 (1): 77-90. https://doi.org/10.1017/S0022336000027566

STARZYK N. 2013. - Jurassic crabs: new characters of carapace diagnostic to known tanidromitid species. Neues Jahrbuch für Geologie und Paläontologie, Abhandlungen 269: 173-187. https:// doi.org/10.1127/0077-7749/2013/0343

STARZYK N. 2015a. - New species of the genus Tanidromites (Decapoda: Brachyura: Tanidromitidae) from the Oxfordian of Poland. Acta Zoologica Cracoviensia 58 (2): 129-136. https://doi. org/10.3409/azc.58_2.129

STARZYK N. 2015b. - Reappraisal of the primitive crab Eodromites, with description of three new species from European localities (Decapoda: Brachyura: Goniodromitidae). Palaeontologia Electronica 18.3.50A: 1-19. https://doi.org/10.26879/513

STARZYK N. 2016. - Three new species of the genus Tanidromites (Decapoda: Brachyura: Tanidromitidae) from the Later Jurassic of Poland. Palaeontologica Electronica 19.3.45A: 1-14. https:// doi.org/10.26879/619

STARZYK N. \& KRZEMIŃSKA E. 2019. - Evolution of the Augenrest in Jurassic Tanidromitidae and Goniodromitidae (Homolodromioidea). Volume of Abstracts, 7th Symposium on Mesozoic and Cenozoic Decapod Crustaceans, 17-21 June, 2019, Ljubljana (Slovenia): 23-24.

STARZYK N., KRZEMIŃSKA E. \& KRZEMIŃSKI W. 2011. — Intraspecific variation in the Jurassic crab Bucculentum hucculentum (Decapoda: Homolodromioidea: Bucculentidae). Neues Jahrbuch für Geologie und Paläontologie Abhandlungen 260: 203-210. https://doi. org/10.1127/0077-7749/2011/0169

STARZYK N., KRZEMiŃSKA E. \& KRZEMIŃSKI W. 2012. — A new crab species from the Oxfordian of Poland (Decapoda: Brachyura: Goniodromitidae). Neues Jahrbuch für Geologie und Paläontologie, Abhandlungen 263 (2): 143-153. https://doi.org/10.1127/0077$7749 / 2012 / 0219$

STUdER T. 1883. - Verzeichniss der Crustaceen, welche während der Reise S. M. S. Gazelle an der an der Westküste von Afrika, Ascension und dem Cap der guten Hoffnung gesammelt wurden. Abhandlungen der Königlich Preussischen Akademie der Wissenschaften zu Berlin 2, 32 p.

TAVARES M. \& SeCRETAN S. 1993. - La notion de thelycum et de spermathèque chez les Décapodes. Comptes Rendus de l'Académie des Sciences, Paris, série 3, 316 (1): 133-138. https://gallica.bnf. fr/ark:/12148/bpt6k54767821/f137.item

TUCKER A. B. 1998. - Systematics of the Raninidae (Crustacea: Decapoda: Brachyura), with accounts of three new genera and two new species. Proceedings of the Biological Society of Washington 111 (2): 320-371. https://biodiversitylibrary.org/page/35459074

Tucker A. B., Feldmann R. M., Holland F. D. \& Brinster K. F. 1987. - Fossil crab (Decapoda; Brachyura) fauna from the Late Cretaceous (Campanian-Maastrichtian) Pierre Shale in Bowman County, North Dakota. Annals of Carnegie Museum 56 (17): 275-288. https://biodiversitylibrary.org/page/52460314

Tudge C. C., Scheltinga D. M., Jamieson B. G. M., Guinot D. \& Richer De Forges B. 2014. - Comparative ultrastructure of the spermatozoa of the Majoidea (Crustacea, Decapoda, Brachyura) with new data on six species in five genera. Acta Zoologica 95: 1-20. https://doi.org/10.1111/azo.12005
Tsang L. M., Schubart C. D., Ahyong S.T., Lai J., Au E., Chan T. Y., NG P. K. L. \& CHU K. H. 2014. — Evolutionary history of true crabs (Crustacea: Decapoda: Brachyura), and the origin of freshwater crabs. Molecular Biology and Evolution 31: 1173-1187. https://doi.org/10.1093/molbev/msu068

Van Bakel B. W. M., Fraaije R. H. B., Jagt J. W. M. \& Artal P. 2008. - An unexpected diversity of Late Jurassic hermit crabs (Crustacea, Decapoda, Anomura) in central Europe. Neues Jahrbuch für Geologie und Paläontologie, Abhandlungen 250: 137-156. https://doi.org/10.1127/0077-7749/2008/0250-0137

Van Bakel B. W. M., Artal P., Fraaije R. H. B. \& Jagt J. W. M. 2009. - A new Early Oligocene crab (Decapoda, Brachyura, Dromiacea) from northwest Belgium, with comments on its palaeobiology. Geologica Belgica 12: 45-57.

Van Bakel B. W. M., Guinot D., Corral J. C. \& Artal P. 2012a. - Graptocarcininae n. subfam., an extinct subfamily of Dynomenidae Ortmann, 1892 (Crustacea, Brachyura, Podotremata). Zootaxa 3534: 40-52. https://doi.org/10.11646/ zootaxa.3534.1.3

Van Bakel B. W. M., Guinot D., Artal P., Fraaije R. H. B. \& JaGT J. W. M. 2012b. - A revision of the Palaeocorystoidea and the phylogeny of raninoidian crabs (Crustacea, Decapoda, Brachyura, Podotremata). Zootaxa 3215: 1-216. https://doi. org/10.11646/zootaxa.3215.1.1

VAn BAKel B. W. M., Guinot D., Jagt J. W. M. \& FraAije R. H. B. 2012c. - Mithracites takedai, a new homoloid crab (Decapoda, Brachyura) from the Lower Cretaceous (Aptian) of Colombia, in KomATSu H., OKUnO J. \& FUKUOKA K. (eds), Studies on Eumalacostraca: a Homage to Masatsune Takeda. Crustaceana Monographs 17: 81-90. https://doi.org/10.1163/9789004202894_007

Van Bakel B. W. M., Robin N., Charbonnier S. \& SaWard J. 2017. - Revision of Dromilites bucklandii (Crustacea, Decapoda, Brachyura): type material revealing its real identity, a junior synonym, and a new species. Palaeontologia Electronica 20.3.61A: 1-12. https://doi.org/10.26879/813

VAN STRaelen V. 1925. - Contributions à l'étude des Crustacées décapodes de la période jurassique. Mémoires de l'Académie royale de Belgique, 2ème série, 7: 1-462.

VAN STRAELEN V. 1936. — Sur quelques crabes du Sahélien moyen des environs d'Oran (Algérie). Bulletin de la Société géologique de France (5) 6: 473-480.

Vega F. J., JaCKson J. \& Ossó A. 2014. — Exceptional preservation of a late Cenomanian (Late Cretaeous) crab from Texas, U. S. A. Boletín de la Sociedad Geológica Mexicana 66 (1): 215-221. https://doi.org/10.18268/BSGM2014v66n1a15

VERMEIJ G. J. 2002. - Evolution in the consumer age: predators and the history of life, in KOWALEWSKI M. \& KELLEY P. H. (eds), The Fossil Record of Predation. The Paleontological Society Paper 8: 375-393. https://doi.org/10.1017/S1089332600001169

Wear R. G. \& BATHAM E. J. 1975. - Larvae of the deep sea crab Cymonomus bathamae Dell, 1971 (Decapoda, Dorippidae) with observations on larval affinities of the Tymolinae. Crustaceana 28: 113-120. https://doi.org/10.1163/156854075X00658

Wehner G. 1988. - Über die Prosoponiden (Crustacea, Decapoda). Inaugural-Dissertation zur Erlangung des Doktorgrades der Fakultät für Geowissenschaften der Ludwig-Maximilians-Universität zu München. Wehner publisher, Munich: 1-154.

WiLliamson D. I. 1965. - Some larval stages of three Australian crabs belonging to the families Homolidae and Raninidae, and observations on the affinities of these families (Crustacea: Decapoda). Australian Journal of Marine and Freshwater Research 16: 369-398. https://doi.org/10.1071/MF9650369

Withers T. H. 1932. - A Liassic crab, and the origin of the Brachyura. Annals and Magazine of Natural History, Series 10, 9: 313-323. https://doi.org/10.1080/00222933208673499

Withers T. H. 1951. - Some Jurassic and Cretaceous crabs (Prosoponidae). Bulletin of the British Museum (Natural History) 1: 173-185. https://biodiversitylibrary.org/page/36367730 
Wolfe J. M., Breinholt J. W., Crandall K. A., Lemmon A. R., Moriarty Lemmon E., Timm L. E., Siddall M. E. \& BRACKENGrISSOM H. D. 2019. - A phylogenomic framework, evolutionary timeline, and genomic resources for comparative studies of decapod crustaceans. Proceedings of the Royal Society B: Biological Sciences 286: 20190079. https://doi.org/10.1098/rspb.2019.0079

Wright C. W. \& Collins J. S. H. 1972. - British Cretaceous Crabs. Monograph of the Palaeontographical Society of London 126 (533): 1-113.
Wright C. W. \& Collins J. S. H. 1975. - Glaessnerella (Crustacea Decapoda, Cymonomidae), a replacement name for Glaessneria Wright \& Collins, 1972 non Takeda \& Miyake, 1969. Palaeontology 18 (2): 441. https://biodiversitylibrary. org/page/49759946

Wright C. W. \& Wright E. V. 1950. - Some dromiacean crabs from the English Cretaceous. Proceedings of the Geologists' Association 61: 13-27. https://doi.org/10.1016/S00167878(50)80009-3 